Published in final edited form as:

Prog Neurobiol. 2009 February ; 87(3): 133-170. doi:10.1016/j.pneurobio.2008.09.009.

\title{
Nanotechnology, nanotoxicology, and neuroscience
}

\author{
Won Hyuk Suh ${ }^{\mathrm{a}}$, Kenneth S. Suslick ${ }^{\mathrm{b}}$, Galen D. Stucky ${ }^{\mathrm{a}}$, and Yoo-Hun Suhc, ${ }^{\text {* }}$ \\ aDepartment of Chemistry and Biochemistry, Materials Department, University of California, Santa \\ Barbara, CA 93106, USA \\ ${ }^{b}$ Department of Chemistry, School of Chemical Sciences, University of Illinois at Urbana- \\ Champaign, 600 S. Mathews Ave., Urbana, IL 61801, USA \\ 'National Creative Research Initiative Center for Alzheimer's Dementia, and Neuroscience \\ Research Institute, Medical Research Center, Department of Pharmacology, College of Medicine, \\ Seoul National University, 28 Yeongeon-dong, Jongno-gu 110-799,South Korea
}

\section{Abstract}

\begin{abstract}
Nanotechnology, which deals with features as small as a 1 billionth of a meter, began to enter into mainstream physical sciences and engineering some 20 years ago. Recent applications of nanoscience include the use of nanoscale materials in electronics, catalysis, and biomedical research. Among these applications, strong interest has been shown to biological processes such as blood coagulation control and multimodal bioimaging, which has brought about a new and exciting research field called nanobiotechnology. Biotechnology, which itself also dates back $\sim 30$ years, involves the manipulation of macroscopic biological systems such as cells and mice in order to understand why and how molecular level mechanisms affect specific biological functions, e.g., the role of APP (amyloid precursor protein) in Alzheimer's disease (AD). This review aims (1) to introduce key concepts and materials from nanotechnology to a non-physical sciences community; (2) to introduce several stateof-the-art examples of current nanotechnology that were either constructed for use in biological systems or that can, in time, be utilized for biomedical research; (3) to provide recent excerpts in nanotoxicology and multifunctional nanoparticle systems (MFNPSs); and (4) to propose areas in neuroscience that may benefit from research at the interface of neurobiologically important systems and nanostructured materials.
\end{abstract}

\section{Keywords}

Nanotechnology; Nanotoxicology; Neuroscience; Nanoscience; Toxicology; Neurobiology; Nanoparticles; Nanostructured; Nanobiotechnology; Nano—bio interface; Engineered nanomaterials; Nanomaterials; Multifunctional nanoparticle

\section{Introduction to nanomaterials}

The science and technology of nanoscale materials has roots as old as chemistry itself, from the formulation of precious metal colloids for medieval stain glass to the Roman's use of cement (Bergna, 1994; Delatte, 2001; Edwards and Thomas, 2007; Faraday, 1847; Sanchez et al., 2003). As a separate field, nanoscience and nanotechnology began to emerge some 20 years ago (Hodes, 2007), and a database search yields more than 500 review articles in this area. For our discussions here, we will focus on materials with domain dimensions below $100 \mathrm{~nm}(\mathrm{~nm}$

(C) 2008 Elsevier Ltd. All rights reserved.

*Corresponding author. Tel.: +82 2740 8285; fax: +82 2745 7996. E-mail address: yhsuh@ snu.ac.kr (Y.-H. Suh). . 
$=1$ billionth of a meter), e.g. length scales below those observable by simple optical or even confocal microscopy (Fig. 1). For scale, nanosized objects are 100-10,000 times smaller than the size of mammalian cells.

The molecular level contents of neurobiologically important systems are proteins, nucleic acids, lipid bilayers, metal ions, and small molecules, whose sizes are shown schematically in Fig. 1 (lower panel). At this size scale, the most important structural characterization techniques include X-ray crystallography, nuclear magnetic resonance (NMR), scanning, transmission electron microscopy, and optical/fluorescence/confocal microscopy. For instance, the amyloid precursor protein (APP) (Kong et al., 2007; Suh and Checler, 2002) shown as a biomolecule in Fig. 1 (lower panel) is an actual X-ray crystal structure visualized using VMD (visual molecular dynamics) (Humphrey et al., 1996). Compared to this biomolecule, a small molecule such as dehydroevodiamine hydrochloride (DHED) (Ahn et al., 2004;Decker, 2005; Park et al., 1996,2000; Suh et al., 2005), a potent Alzheimer's disease (AD) candidate therapeutic agent, is much smaller in size. Micron sized nanostructured microspheres are readily endocytosed into the cytosol and can carry nanosized cargo into neurobiologically relevant systems (Suh et al., 2006a,b). In this review, we examine several important nanostructured materials that may interface well with neurobiologically important systems and find use in the neuroscience community.

\section{Engineered nanomaterials: overview and recent advances}

\subsection{The first nanoparticles: carbonaceous nanomaterials}

Arguably the oldest and easiest nanoparticles to make are of carbon: the use of carbon black from fuel-rich partial combustion for ink, pigment, and tatoos dates back more than 3000 years, but still remains a topic of current research interest (Lee et al., 2006b; Lu and Schuth, 2006; Xia et al., 2006b). The largest modern use of nanophase carbon, by far, is as filler in rubber tires, for which $>8$ million metric tons are produced each year; roughly another million tons are used as pigments (What is carbon black?). Various synthetic carbon materials exist that have nanometer scale features. Macroporous carbon materials can be created via inverted opal synthesis (colloidal template method) but these materials are usually amorphous (Lee et al., 2006b). Crystalline carbon nanomaterials can be created via high voltage arc electricity, laser ablation, or growth under high temperatures with metal-based precursors or nanoparticles as catalysts (Dai, 2002; Jiao et al., 1996; Satishkumar et al., 1999). In addition, fullerenes (e.g. $\mathrm{C}_{60}, \mathrm{C}_{72}$ ) and carbon nanotubes, either single-walled or multi-walled, can be synthesized in this way (Burghard, 2003; Dai, 2002; Dosa et al., 1999; El Hamaoui et al., 2005; Hayashi et al., 1996; Hu et al., 1999; Iijima, 1991; Iijima et al., 1999; Iyer et al., 2003; Kroto et al., 1985; Lei et al., 2006; Lu et al., 2006; Odom et al., 1998; Rinzler et al., 1998; Sano et al., 2003; Terrones et al., 1997; Thess et al., 1996). These more sophisticated carbon nanomaterials are finding a variety of applications for electronics (Dai, 2002; Odom et al., 1998), catalysis (Kim et al., 2000), chemical sensing (Barone et al., 2005; Heller et al., 2005, 2006; Jeng et al., 2006; Zheng et al., 2003), and cell biology (Carrero-Sanchez et al., 2006; Dumortier et al., 2006; Kam et al., 2004; Yan et al., 2006). The scope of this review limits us from extensively discussing carbon-based nanomaterials; we will, however, cover some newer versions of carbon nanomaterials in Section 3.2.

Interestingly for neuroscience, Silva (2005) recently reviewed a list of fullerene $\left(\mathrm{C}_{60}\right)$ derivatives studied both in vitro and in vivo for their neuroprotective ability. The model material responsible for providing neuroprotection is fullerenol which is hydroxyl functionalized fullerene. More recently Yamawaki and Iwai (2006), however, reported the in vitro toxicity of fullerenols in human umbilical vein endothelial cells (ECs) that were treated with 1-100 $\mu \mathrm{g} /$ $\mathrm{mL}$ concentrations (average diameter 4.7-9.5 $\mathrm{nm}$ ) for a day which induced cytotoxic morphological changes as well as showing cytotoxicity via LDH and WST assays in a dose- 
dependent manner. Eight day chronic treatment $(10 \mu \mathrm{g} / \mathrm{mL})$ also inhibited cell attachment and delayed EC growth. Varying biological effects of a single nanomaterial such as the hydroxy fullerene offers a clear demonstration of extraordinary situations where a single nanomaterial plays both beneficial (neuroprotection) and unfavorable (specific cell toxicity response) roles within a biological system. Choosing, utilizing, and assessing toxicity of any nanostructured material for biomedical applications are not trivial tasks especially for neuroscience applications where biological systems involved in the bioprocesses are more vital functions such as the central nervous systems (CNS) which include the brain and the spinal cord.

Carbon nanotubes, owning to their structural robustness and synthetic versatility, have been utilized in multiple biomedical applications including tissue engineering. Recently, Kotov and co-workers have formulated a nanocomposite matrix comprised mainly of single-walled carbon nanotubes (SWCNT) which was utilized as a growth substrate for murine embryonic neural stem cells (Jan and Kotov, 2007). Differentiation, growth, and biocompatibility reported by the authors supported positive uses of such nanocomposites but a more recent article by Zhu et al. (2007) showed DNA damages (genotoxicity) induced by multi-walled carbon nanotubes (MWCNT) in mouse embryonic stem cells. This additional example clearly demonstrates realistic dilemmas researchers can face while choosing carbon-based as well as other types of nanostructured materials for biomedical uses.

\subsection{Porous nanomaterials}

Long before the recent interest in nanoscience, the IUPAC divided porous materials and pore size into three categories, microporous $(<2 \mathrm{~nm})$, mesoporous $(2-50 \mathrm{~nm})$, and macroporous ( $>50 \mathrm{~nm}$ ) (Rouquerol et al., 1994; Ying et al., 1999; Zdravkov et al., 2007). There is some confusion, however, in the increasingly popular use of "nanoporous" to describe all three of these categories. Synthesis methods for such materials range from crystal engineering to cooperatively assembled template methods and sol—gel chemistry (Boettcher et al., 2007; Eddaoudi et al., 2001). In this section an overview of the synthetic methods to achieve mesoand macroporosity will be briefly covered.

One of the biggest challenges in porous material synthesis is the precise controlling of the pore size while maintaining overall structure integrity as well as overall size (Alfredsson et al., 1994). Mesoporous materials such as MCM-41 (Beck et al., 1992)and SBA-15 (Zhao et al., 1998a,b), and MCF (Han et al., 2007, 1999; Schmidt-Winkel et al., 1999) have been the most successful porous materials to date and their application in catalysis (Boettcher et al., 2007; Corma, 1997; Ying et al., 1999) has been particularly interesting. Synthesis of mesoporous materials involves the use of a surfactant or block copolymer and a polymerizing inorganic precursor, preferably carried out at a $\mathrm{pH}$ near the isoelectric point (IEP) of the inorganic species (Huo et al., 1994). It is a cooperative molecular assembly process (Monnier et al., 1993; Huo et al., 1994) that makes use of all components of the synthesis solution.

Macroporous material syntheses using colloidal template methods have been the focus of recent research. Previously prepared colloidal particles (which can range in size from a few microns down to a few nanometers) are assembled into a "colloidal crystal", a regular array of close packed spheres, dried, and then a matrix-forming material is interspersed into the interstices between the colloidal particles. This initially liquid solution is then solidified (e.g. polymerized through heat or chemical reduction) and the original colloid particles removed by dissolution or pyrolysis, leaving a porous material whose pore size is controlled by the initial colloid. Materials of these kinds are sometimes referred to as inverse opals. Application of such macroporous materials has been in catalysis (Chai et al., 2004; Yoon et al., 2005), photonics (Norris and Vlasov, 2001; Vlasov et al., 2001), and tissue engineering (Liu et al., 2005b; Zhang et al., 2005), depending on the pore size and type of material. The new trend in porous material synthesis is to combine different levels of porosities (e.g. microporosity with macroporosity) 
or inclusion of porosities into materials whose overall dimensions are sub-micron (Yang et al., 1998; Yoon et al., 2002). The bio-applications of such materials include bioseparation, biosensing, drug delivery, and controlling bioprocesses in blood clotting (Blumen et al., 2007; Lee et al., 2006b; Ostomel et al., 2006a,b).

Briefly we will highlight few advances of porous nanomaterials that were designed and successfully used in several key biological applications. First, on the tissue engineering front, Desai and researchers utilized porous aluminum oxide membranes (prepared via electrochemical etching) as cell growth substrates for osteoblast cells which was a comparison study among several different porous and non-porous aluminum oxides. It turns out that the as-prepared nanoporous $\mathrm{Al}_{2} \mathrm{O}_{3}$ substrates showed improved attachment and proliferation of osteoblast cells both short-term and long-term compared to other examples (Swan et al., 2005a,b). More recently, Schmuki and co-workers have demonstrated that vertically aligned titanium oxide nanotubes (also prepared via electrochemical etching) can effectively direct the adhesion and proliferation of mammalian cells on anodized porous substrates (Park et al., 2007). The critical factor in the case of mesenchymal stem cells' adhesion, spreading, growth, and differentiation was the diameter of the as-prepared nanotubes which meant that the porosity of the substrate controlled the bioprocesses involved in stem cell biology to a noticeable degree. Adhesion and spreading of the mesenchymal stem cells (MSCs) were impaired which led to reduction of cellular level activity and eventual cell death when the diameter of the nanotubes increased beyond $50 \mathrm{~nm}$. Such a dramatic influence arising from artificially created sub-100 $\mathrm{nm}$ size features is a direct testament that nanotechnology can effectively influence biological processes via careful tuning of variables such as size, volume, and surface electronic characteristics. Secondly, work related to blood coagulations, Grimes and co-workers showed that the electrochemically produced $\mathrm{TiO}_{2}$ nanotubes ( $100 \mathrm{~nm}$ diameter with aspect ratio of approximately 1000) can enhance blood clotting rates (Roy et al., 2007). Metal oxide hemostatic agents such as porous zeolites and bioglass $\left(\mathrm{SiO}_{2}-\mathrm{P}_{2} \mathrm{O}_{5}-\mathrm{CaO}\right)$ have been reported much earlier in time by Stucky and co-workers to effectively enhance the rate of clotting times both in vitro and in vivo (Ostomel et al., 2006a,b,c). These efforts demonstrated by the Stucky group illustrated that porous metal oxides can play key roles in controlling the bioprocesses involved in the blood clotting cascade. Details involved in Stucky group's work in the field of hemostasis will be provided in a later section within this review.

\subsection{Magnetic nanomaterials}

Magnetic properties of materials are controlled by temperature, applied field, alignment and relative orientation of the magnetic domains, and electronic spin states (Hyeon, 2003). Additionally, the size of the particles greatly alters magnetic properties (Campbell et al., 1999). As particle size is decreased to the few tens of nanometers, ferromagnetic materials will have only a single magnetic domain, and all magnetic spins within that domain will be aligned, while thermal motion of such particles relative to one another will control the bulk magnetic properties. These materials are referred to as superparamagnetic and are excellent MRI (magnetic resonance imaging) contrast agents (Gupta and Gupta, 2005; Murray et al., 2001; Wang et al., 2001).

Superparamagnetic inorganic oxides (SPIO) such as $\mathrm{Fe}_{3} \mathrm{O}_{4}$ are proving especially useful in tumor targeting and MRI imaging in biomedical applications (Huh et al., 2005; Jun et al., 2005; Lee et al., 2003; Song et al., 2005). Water-soluble superparamagnetic iron oxide (WSIO) nanoparticles, for instance, can be additionally passivated with cancer targeting agents (e.g. antibodies) and in vivo MRI imaging can be done to monitor the circulation and specific attachment to the cancer induced area (Huh et al., 2005). Iron oxides have also been utilized in bioimaging for neuroscience (Atanasijevic et al., 2006; Bulte et al., 2001; Cengelli et al., 2006; Dunning et al., 2004 ${ }^{2006}$; Faber et al., 2007; Liu et al., 2007b; Moore et al., 2000; 
Muldoon et al., 2005; Neuwelt et al., 2007; Petropoulos et al., 1995; Rock et al., 2005; Sykova and Jendelova, 2007; Wadghiri et al., 2003). A recent review by Sykova and Jendelova (2007) highlights the use of labeled SPIO imaging agents for tracking migration and fate of adult stem cells in vivo with a focus in the central nervous system. Cell labeling can be done either on the surface of the cell or internalized into the cytoplasm but not the nucleus. The labeling contrast agent is usually comprised of a superparamagnetic core (e.g. $\mathrm{Fe}_{3} \mathrm{O}_{4}$ ), a watersoluble protective coat with functionalizable chemical groups (e.g. thiol, carboxylic acid), and a targeting agent (e.g. antibody).

Juillerat and co-workers have studied several different SPIO nanoparticles (both synthesized and commercially available) on their biological effects on brain-derived endothelial cells and microglial cells (Cengelli et al., 2006). Among the coated SPIO's, active uptake was observed in the amine functionalized case which should have a positive surface charge. This observation is in agreement with a previous report by Cheon and co-workers where cationic water-soluble iron oxide nanoparticles were efficiently transported into neural stem cells in comparison to the anionic counterparts (Song et al., 2005). The ideas behind such studies where particle uptake was increased via surface charge modification are two-fold: one is to increase the signal level of MRI and the other to achieve drug or small molecule delivery to specific cells and tissues. Recent researches have shown, however, that cationic surface charges (Xia et al., 2006a) and iron oxide (Pisanic et al., 2007) itself may have detrimental effects on cells so extensive toxicology experiments should follow any type of in vitro and in vivo studies utilizing cationic iron oxide nanoparticles where dosage and procedures are carefully tuned and monitored.

Liu et al. (2007a,b) demonstrated the use of modified SPIO nanoparticles that can target cellular mRNAs and detect active transcriptions of specific mRNAs in vivo using antisense imaging agents (e.g. phosphorothioate oligodeoxynucleotide) coupled with MRI imaging. This type of research can lead to the development of real-time MRI detection methods where CNS disease models linked to mRNA alteration can be identified. On a slightly different note, Turnbull and Wisniewski, along with their co-workers, used $A \beta 1-40$ peptide modified iron oxide nanoparticles to detect $A \beta$ in transgenic mice in vivo (Wadghiri et al., 2003). In summary, magnetic nanomaterials, especially superparamagnetic iron oxides, can be utilized in three distinctive neurological applications which include tracking transplanted cells (e.g. stem cells), identifying transcription efficiencies, and detecting amyloid beta peptides in diseased brains.

\subsection{Zeolites and clays}

Dramatic responses observed in biomolecules and biomolecular processes involved in interfacial phenomena that involve inorganic surfaces are well demonstrated in biomineralization processes (Zaremba et al., 1996), biomolecular chromatographic separations (Kimura et al., 2004), supported enzyme activities and lifetime (Carrado et al., 2004; Han et al., 2002) and protein folding and denaturation (Charache et al., 1962). Mentioned earlier in Section 2.2, the development of potent wound-dressing materials (blood clotting agents) that are capable of arresting hemorrhage due to traumatic injury is another emerging application using materials chemistry to control bioprocesses (Ellis-Behnke et al., 2006; Fischer et al., 2005; Marris, 2007; Ostomel et al., 2006a) and one of the most effective wound-dressing materials currently available is a nanoporous zeolite called QuikClot ${ }^{\circledR}(\mathrm{QC})$ (Z-Medica). Alam et al. (2005) reported that among several different advanced wound-dressing materials tested using a swine model of fatal femoral injury QC exhibited the highest rates of survival.

The Stucky group has found that the isoelectric points of different inorganic surfaces, as measured in simulated body fluid (SBF), can be used as primary determinants to selectively and in a predictable manner accelerate or inhibit blood coagulation (Baker et al., 2007; Ostomel et al., 2007). One example of the many metal oxides based materials that were investigated was clays. Chemical and physical properties, including variable swelling capacities, particle 
morphologies, surface charge, and the ability to control the local electrolyte balance through ion exchange are tunable variables available in clay science. In a recent study, it was found that surface charge in SBF for clays such as kaolin correlated very well with the wide range of blood clotting activities of porcine whole blood or plasma (Baker et al., 2007).

Surface charge modulation is not the only way to direct the bioprocesses associated with the blood coagulation cascade as seen in the case of QC where local heating, dehydration, and electrolyte release also contribute to the overall biological process (Baker et al., 2007). Recent studies of the hemostasis properties of high-surface-area porous silica, the Stucky group has shown that the selective variation of window/pore sizes at the sub-50 $\mathrm{nm}$ range strongly dictated the rate at which blood clots are formed in human plasma (Baker et al., 2008). This indicates that pore sizes in this size range directly impact the accessibility and diffusion of clottingpromoting proteins to and from the interior surfaces of the porous silica particles. These studies point toward a critical pore size, $\geq 20 \mathrm{~nm}$, at which clotting speed is maximized. Interestingly, this size regime very closely resembles the pore size at which electrochemically prepared porous $\mathrm{TiO}_{2}$ nanotubes affected mesenchymal stem cell fate as highlighted earlier in this review (Park et al., 2007). Another important capability of such porous metal oxides is that the clotting times of plasma can be even further dramatically reduced by immobilizing selected enzymes within the large pores. This validates the utility of enzyme-immobilized mesoporous silicas in biomedical applications and further expands their possible use in the field of drug delivery systems (Han et al., 1999, 2002; Kim et al., 2006a, 2007b; Luckarift et al., 2004; Tischer and Wedekind, 1999). Porous metal oxides because of their surface chemistry and high internal surface area will allow facile incorporation of proteins in high loading. Fine tuning of nanostructured surfaces including pores and expanded structures to facilitate neurochemicals and important proteins involved in various biological pathways responsible for key neurological functions will prove to be key factors in the development of nanobiotechnology in the field of neuroscience along with the ability to incorporate and release such entities in a controlled fashion.

\section{Nano-bio interface and nanotoxicology}

\subsection{Nano-bio interface}

Proteins and nucleic acids have been the focus of many types of research involving nanotechnology (Kim et al., 2006a; Samori and Zuccheri, 2005; Sarikaya et al., 2003; Seeman, 2003; Zhao and Zhang, 2006). A single cell, usually tens of microns in size, is huge compared to a $10 \mathrm{~nm}$ nanoparticle (Figs. 1 and 2). In this sense, researchers around the world have been utilizing various inorganic, organic, and composite nanoparticles to study biological processes involved in drug delivery and cellular level bioimaging (Akerman et al., 2002; Allen and Cullis, 2004; Arap et al., 1998; Gref et al., 1994; Martin and Kohli, 2003). Recently, growing number of papers examine the interaction between a protein and a nanoparticle (Klein, 2007; Sui et al., 2005; Taylor et al., 2000). Compared to a $10 \mathrm{~nm}$ nanoparticle (Fig. 2), the APP and a small drug molecule (e.g. DHED) is extremely small which makes probing biologically relevant molecules on nanoparticles extremely difficult. In reality, an injected nanoparticle into a living system will have an uncountable number of interactions with the surrounding system regardless of size. Efforts studying the interface between nanostructured materials and biological systems starting with proteins and then the cell will be a key development that will aid in the study of bio-systems relevant to neuroscience, pharmacology, and medicine.

Studying the bio-nano interface is a very different task since there are no simple ways of probing the interaction in real time or in situ. On the other hand, nanotoxicology (the examination of bioeffects of nanomaterials) is a rapidly developing field of some direct relevance. Over the past few years, substantial efforts have begun in the study of the toxic effects of nanomaterials on the environment and living systems. For instance, University of 
California has a focused nanotoxicology program sphere headed by UCLA and UCSB under its UC Toxic Substances Research and Teaching Program

(http://www.bren.ucsb.edu/news/press/nanotoxicology.htm;

http://www.cnsi.ucla.edu/staticpages/education/nanotox-program). As a city, Berkeley (CA), for the first time in US history, has decided to regulate nanotechnology by law with UC Berkeley and LBNL (Lawrence Berkeley National Laboratory) being involved in many nanotech projects but without any implemented safety related protocols (Berkeley, 2006; Monica et al., 2007). Rice University has a center called CBEN (Center for Biological and Environmental Nanotechnology) and an organization called ICON (International Council on Nanotechnology) dedicated to establishing a database for nanotechnology based materials (http://cben.rice.edu/; http://icon.rice.edu). The National Cancer Institute (NCI), not long ago, started a separate institution called NCL (Nanotechnology Characterization Laboratory) headed by a chemist investigating nanomaterials that are below $100 \mathrm{~nm}$ on a proposal submission and approval basis (http://ncl.cancer.gov/). Internationally, IBN (Institute of Bioengineering and Nanotechnology) governed by A*STAR (Agency for Science, Technology and Research) in Singapore is an interdisciplinary research park that brings together nanometer scale science with control over biological system (http://www.ibn.a-star.edu.sg/). IBN is headed by a materials scientist which is a sign that the institution has an emphasis more in the materials they make which will help to alleviate transfer of nanotechnology to be implemented in biotechnology.

In essence, a fundamental understanding of nanomaterial toxicology (nanotoxicology) is highly desirable both from the material's stand point as well as from the biological system's point of view. With the increase of commercial products from cosmetics to tennis balls, toxicology evaluations of nanoscale materials should receive greater attention than ever before whether it is the general public, the government, or the personnel involved in the development of nanomaterials (Colvin, 2003; Maynard et al., 2006; Nel et al., 2006; Oberdorster et al., 2005). For the field of neuroscience, the lessons learned from these nanotoxicology studies should help researchers to better choose the type of nanomaterial that can be utilized for studying, for instance, the synaptic plasticity of a neuron. In hopes of doing this, we will review the literature of how nanotoxicology has developed and provide few tables to ease the selection process of materials. With current data, however, it is often difficult to ascertain the toxicity of specific nanomaterials because, as with any small molecule (e.g. pharmaceuticals), toxicity is dose, exposure and pathway dependent. In addition, nanotoxicology studies on animals or cultured cells alone cannot predict in a good manner the effects it might have on human beings.

\subsection{Nanotoxicology}

Various types of engineered nanomaterials exist now thanks to the extraordinary and highly focused efforts from both industry and academia in recent years. The number of published papers dealing with just the synthesis of nanostructured materials has grown exponentially (both 2006 and 2007 exceeds 3200 papers) (Fig. 3). Owing to this explosive increase in publications, hundreds of in vitro toxicological studies have been reported (Derfus et al., 2004; Gurr et al., 2005;Oberdorster, 2004;Ramires et al., 2002;Soto et al., 2005;Suh et al., 2006b; Yoshida et al., 2003), as well as numerous reviews and perspectives (Balbus et al., 2007;Borm and Kreyling, 2004;Colvin, 2003;Dobrovolskaia and McNeil, 2007;Garnett and Kallinteri, 2006;Handy and Shaw, 2007;Hardman, 2006;Maynard et al., 2006;Medina et al., 2007; Nel et al., 2006; Oberdorster et al., 2005). In vivo toxicology, on the other hand, which probes toxicity (i.e. $\mathrm{LD}_{50}$, pathology) by inhalation, injection, and oral digestion, involves the test subject to internalize the test sample whether it is a small mice or a large mammal such as a dog or a monkey. It is, however, troublesome to test nanomaterials' toxic effects on whole animals since all of the synthetic engineering (Cushing et al., 2004;Dai, 2002;Huber, 2005;Jeong et al., 2007;Lee et al., 2006b;Lu et al., 2007a;Medintz et al., 2005;Michalet et al., 
2005 ) is donevery specifically by individual research groups and proprietary information on synthesis is hard to get especially from the industry. In addition, preparing/conducting/ regulating an in vivo test is ethically and administratively challenging and individual research efforts have to work in partnership with the institutional approval organization(s) such as IACUC (Institutional Animal Care and Use Committees).

3.2.1. In vitro nanotoxicology-The easiest simple solution in assessing nanomaterial toxicology is utilizing various mammalian cells to test for viability or increase/decrease in a designated inherent biological pathway against chosen engineered nanomaterials. For instance, tetrazolium salt based assays (e.g. MTT (Mosmann, 1983) or WST (Ishiyama et al., 1996; Tominaga et al., 1999) are readily available commercially (i.e. Dojindo, Roche) and straightforward to use. Inorganic oxides (Gurr et al., 2005; Ramires et al., 2002; Soto et al., 2005; Suh et al., 2006b; Yoshida et al., 2003) such as $\mathrm{TiO}_{2}, \mathrm{SiO}_{2}, \mathrm{Fe}_{2} \mathrm{O}_{3}$, carbon-based materials (Jia et al., 2005; Oberdorster, 2004; Sayes et al., 2005; Soto et al., 2005; Zhu et al., 2006) such as nanotubes (Cui et al., 2005a; Donaldson et al., 2006; Garibaldi et al., 2006; Heller et al., 2005; Lam et al., ${ }^{2004}$, 2006; Liopo et al., 2006; Manna et al., 2005; Maynard et al., 2004; Monteiro-Riviere et al., 2005; Shvedova et al., 2003; Singh et al., 2006b), C60, and other nanoparticulates (Derfus et al., 2004; Soto et al., 2005; Yoshida et al., 2003) such as semiconductor quantum dots (Chang et al., 2006; Lovric et al., 2005a,b; Tsay and Michalet, 2005; Voura et al., 2004), metal nanoparticles have been evaluated by various research groups (excerpts given as Tables 1-5). The current biggest challenges which have been mentioned in previous papers (Maynard et al., 2006; Nel et al., 2006) might be establishing standard protocols (e.g. particle preparation and growth condition) and producing a reproducible and credible database, such as MSDS (Materials Safety and Data Sheet) for small molecules and effectively linking the toxicological information with physicochemical properties. It is, however, easy to identify a fairly non-cytotoxic material from seriously cytotoxic ones since materials like $\mathrm{TiO}_{2}$ show very little overall cytotoxicity regardless of method or choice of laboratory (Gurr et al., 2005; Ramires et al., 2002; Soto et al., 2005; Suh et al., 2006b; Yoshida et al., 2003). Of course, there are different results arising from different types of assay conditions, the nature of the nanomaterial synthesis, and differences in physicochemical properties.

Another factor to consider is the fact that all of these nanomaterials are not exposed to a biological system in its pristine state (Fig. 4). Consider the DMEM (Dulbecco's Modified Eagle's Medium) liquid cell media and its contents which contain various inorganic salts, amino acids, vitamins and few other components. At least, six components have molar concentrations over $1 \mathrm{mM}$ while fifteen components (mostly amino acids) have concentrations between 0.1 and $1 \mathrm{mM}$. On top of this, there is approximately $0.1 \mathrm{M}$ of sodium chloride present and the overall molar concentration of small molecules is approximately $0.2 \mathrm{M}$ (or $2 \mathrm{wt} \%$ ). And this does not even include the various proteins in the serum that is usually supplemented in $5-10 \%$ fractions to the cell media. Realistically, when nanoparticles are added to a biologically relevant liquid medium their surface physicochemical properties will change over time depending on their physical conditions such as temperature $\left(37^{\circ} \mathrm{C}\right.$, the incubation temperature), light, and some form of agitation. In fact, several research groups have investigated adsorption of proteins and small molecules on nanomaterials and their effects on biological activity (Chan et al., 2007;Dutta et al., 2007;Wang, 2005; Wiesner, 2006; Yang et al., 2006b). Adsorption chemistry and physics of small molecules and biomolecules onto metal oxides have traditionally been a research topic in the physical sciences (Campbell, 1997;Diebold, 2003;Freund et al., 1996;Hofer et al., 2001;Lavalley, 1996;Rajh et al., 2002) so expanding on such work should greatly aid in the process of assessing nanomaterial toxicology. For instance, Mrksich and Whitesides (1996) wrote a review which dealt with how cells interact with small molecules adsorbed onto surfaces. 
3.2.2. The cell-nanoparticle interface-Eventually, expanding the toxicity studies to mammals should be done but since it is practically impossible to test on a human subject it will be difficult to assess nanomaterials' effects on human beings with just animal studies alone. In addition, as mentioned previously, nanostructured materials will be in contact with some biologically relevant entity once it enters a biological system. This makes any biochemical assay or structural analysis irrelevant just on its own.

Biological effects of nanomaterials with a focus on toxicity have to be addressed since consumer products as well as medical tools increasingly utilize them one way or another (Maynard et al., 2006). Neuroscience has been linked to nanotechnology previously (Silva, 2006) so instead of repeating things from that particular review we would like to focus on biological effects of nanomaterials with a focus on toxicology and excerpts from recent advances that can potentially be beneficial to the neuroscience community. First, we would like to focus on several nanomaterials and show how researchers around the world have tried to assess their toxicity. Fig. 5 shows eight representative schemes of how a cellular organism can be affected by a nanoparticle: the cell—nanoparticle interface.

Reactive oxygen species (ROS) products whether it is inside or outside of the cell can be key factors in nanostructured materials toxicological effects (Nel et al., 2006). Event 1 represents a nanoparticle smaller than a cell (red particle) producing ROS which ultimately will affect cell membrane stability and cell survivability. If this nanoparticle is internalized, ROS production (event 2) (Nel et al., 2006), particle dissolution (event 3) (Borm et al., 2006), and mechanical damage to sub-cellular units (event 4) (Yamamoto et al., 2004) such as the nucleus will be very important events to monitor and analyze. In addition, different functional groups and surface electronics of the nanostructured materials will determine the level of interaction between the nanoparticles and their surroundings (event 5) (Karakoti et al., 2006; Kostarelos et al., 2007). Furthermore, overall size of the particle can play an important role since large particles can potentially induce permanent damage to the cell membrane while small particles can pass through the membrane and do harm inside the cell (event 6) (Yoshida et al., 2003).

Non-spherical particles, on the other hand, might have a different biological response compared to the spherical nanoparticles (event 7) (Geng et al., 2007). Dissolution characteristics of the nanomaterials (whether it is outside the cell or inside) can affect the cell in various ways (event 8) (Borm et al., 2006). Limiting the interaction between a nanoparticle and a cell to eight events is an over simplification and the details of actual phenomena that are happening at the interfaces are very difficult to understand. In addition, the size differences among a $1 \mathrm{~nm}$ small molecule, a $4 \mathrm{~nm}$ protein, and a $10 \mathrm{~nm}$ nanoparticle are huge as shown in Fig. 2. Interaction parameters between these three entities coupled with various other molecules, ions, and particles will make the system highly complex (Fig. 4) to account for in a simple manner so applying systems biology (Ideker et al., 2001; Kitano, 2002a,b) approach could be an interesting option as a longterm research project.

On top of these eight nanotoxicology events, nanomaterials interaction with microbial organisms (Moreau et al., 2007) will be an interesting aspect to consider since biologically contaminated nanostructured materials will have detrimental effects on their utilization in biomedical applications (Fig. 6). For instance, mycoplasmas (Razin, 1978; Razin et al., 1998) have a size range below few hundred nanometers and they have become a rising concern in mammalian cell cultures including stem cells (Chen and Chang, 2005; Cobo et al., 2005, 2007; Rottem and Barile, 1993; Simonetti et al., 2007; Ware et al., 2006). If such microbial organisms integrate themselves readily with engineered nanomaterials their toxic potential as a nanocomposite material could increase which makes probing and understanding nanomaterial's role in controlling and affecting cellular level biological processes (events 18 in Fig. 5) very important to investigate and understand. Toxicology arising from such nanobiocomposites will give new meaning to nanotoxicology and, in fact, will be key issues 
to consider for neuroscientists wanting to use nanotechnology with focuses on neuronal cell systems, brain implantations, and dementia research such as Alzheimer's disease since mycoplasma detection is not trivial and implications have been made on their possible role in human disease action including CNS diseases (Candler and Dale, 2004; Casserly et al., 2007; Daxboeck, 2006; Daxboeck et al., 2003, ${ }^{2005}$; Narita et al., 2005; Pellegrini et al., 1996; Tsiodras et al., 2005; Waites and Talkington, 2004).

3.2.3. Titanium dioxide $\left(\mathrm{TiO}_{2}\right)$ - Titania $\left(\mathrm{TiO}_{2}\right)$ has received much attention in materials sciences and engineering due to its optoelectronic properties (Hashimoto et al., 2005). For example, $\mathrm{TiO}_{2}$ has been utilized as photocatalysts for photochemical hydrogen production and for self-cleaning windows. In the cosmetic industry, titania is the main ingredient in many commercial sunscreens along side $\mathrm{ZnO}$ due to its property of $\mathrm{UV}$ absorption.

The phase mainly responsible for titania's photocatalytic properties is anatase. Other known phases are rutile and brookite. Evaluating and comparing $\mathrm{TiO}_{2}$ toxicology has been the theme of many research groups and the investigations involved assaying for size, content and ROS production. Recent efforts have been focused on engineered nanomaterial toxicology and here we represent few excerpts within the past several years. Yoshida et al. (2003) have reported that $\mathrm{LDH}$ (lactate dehydrogenase) assay revealed $\mathrm{TiO}_{2}$ to be the least toxic material from sub-100 $\mathrm{nm}$ up to $1 \mu \mathrm{m}$. According to their studies toxicology assessed using cell membrane damage assays, metal oxides are toxic in the following order: $\mathrm{TiO}_{2}<\mathrm{Al}_{2} \mathrm{O}_{3}<\mathrm{SiO}_{2}$ regardless of size under $1 \mu \mathrm{m}$. This study, however, does not probe different types of $\mathrm{TiO}_{2}$. For an overview study of cell toxicology in relation to $\mathrm{TiO}_{2}$ particle size and crystal phase, Sayes et al. (2006) and Warheit et al. (2006) have done studies with dermal fibroblasts and human lung epithelial cells as well as with rats which suggest that photoactivation of anatase $\mathrm{TiO}_{2}$ will increase cytotoxicity but concentrations over $100 \mathrm{mg} / \mathrm{mL}$ will be significant enough to cause any ill effects. Soto et al. $(2005,2007)$ have also done a correlation study between particle size, aggregation and toxicology using cellular experimental protocols. In these studies TEM is extensively used to analyze the particle sizes and the results suggest that $\mathrm{TiO}_{2}$ are much less cytotoxic compared to other types of nanomaterials such as carbon nanotubes and $\mathrm{SiO}_{2}$. In a unique synthesis, Suh et al. (2006b) have produced anatase phase $\mathrm{TiO}_{2}$ microspheres that have nanometer features and also showed that $\mathrm{TiO}_{2}$ is biocompatible. The cause for concern in $\mathrm{TiO}_{2}$ toxicity studies are in the cases where researchers showed genotoxicity (Turkez and Geyikoglu, 2007; Wang et al., 2007a) associated with titania and with particles that are nonspherical (Yamamoto et al., 2004). Table 1 summarizes $\mathrm{TiO}_{2}$ nanotoxicology in recent years with a minimum focus on in vivo inhalation toxicology and a focus on cellular level toxicity studies. Utilizing nanotechnology in neuroscience will likely not involve inhalation of particles compared to injection and installation of the nanostructured materials either as injectable devices or implantable machines and tools.

Prosthetic devices including neuroprosthetics require well-defined device characteristics such as mechanical and chemical properties. Titanium based materials have been the choice of many for implants. In a recent study, Palmieri et al. (2007) have investigated into comparing the effects of nano-sized synthetic anatase $\mathrm{TiO}_{2}$ (prepared via the sol-gel route surface) coated onto surfaces against osteoblast-like cells (MG63) for their role in gene regulation using microRNA (miRNA) microarray analyses. miRNAs are small 19-23 nucleotide noncoding RNAs and play a crucial role in the post-transcriptional regulatory process. miRNAs regulate the expression of other types of genes by repressing or cleaving translation of their messenger RNA targets and they have been shown to be an intricate part of neurobiologically important pathways (Kosik, 2006; Kosik and Krichevsky, 2005). The number of known miRNA's are limited to approximately 500, considering this and the shown roles of miRNA it may be an important molecular level screening method that has become available for any type of nanoscience-related neuroscience projects. Interestingly within the past two years, Gao and 
researchers have utilized nanotechnology to electrochemically detect miRNA at the pM to fM range (Fan et al., 2007; Gao and Yang, 2006) and the Corn group used nanoparticle amplified optical detection methods which allowed the detection lower limit to reach attomolar concentrations (Fang et al., 2006). Recent advances involving nanotechnology and miRNA will foster new and exciting interdisciplinary research linking biology and physical sciences.

3.2.4. Silicon dioxide $\left(\mathrm{SiO}_{2}\right)$ - In comparison to $\mathrm{TiO}_{2}$, silica $\left(\mathrm{SiO}_{2}\right)$ has been studied more widely due to an occupational lung disease called silicosis which is linked to crystalline phase silica (Brunner et al., 2006; Jovanovic et al., 2006). Unlike $\mathrm{TiO}_{2}$, however, research involving $\mathrm{SiO}_{2}$ in the field of nanotechnology deals mainly with amorphous phase silica (Bharali et al., 2005; Chowdhury and Akaike, 2005; Gemeinhart et al., 2005). Here we will introduce few good examples of $\mathrm{SiO}_{2}$ nanostructured materials with a focus on recent synthetic particles that have multifunctionality (see Section 4.2). $\mathrm{SiO}_{2}$ sub-50 nm silica nanoparticles incorporating a fluorophore and an MRI agent were synthesized and cell viability was checked with a one day colorimetric tetrazolium assay using monocyte cells which revealed the non-toxic nature of that particular multifunctional particle (Rieter et al., 2007a). Mesoporous $\mathrm{SiO}_{2}$ spheres have been prepared and utilized in several biological applications in the past few years including drug delivery studies (Slowing et al., 2007). In a recent anti-cancer drug delivery study done by UCLA (Lu et al., 2007b), approximately $130 \mathrm{~nm}$ amine group functionalized mesoporous $\mathrm{SiO}_{2}$ spheres were formed and surface modified with alkyl phosphate groups. Cytotoxicity tests on several different cancer cell lines (e.g. PANC-1, AsPC-1) revealed practically no toxicity unless the anti-cancer drug was loaded and subsequently released over time. In another protein, polymer functionalized $\mathrm{SiO}_{2}$, luminescent nanobeads of approximately $20 \mathrm{~nm}$ were tested for its cytotoxicity $(<6 \mathrm{~h}$ ) via apoptosis and necrosis assays (flow cytometry) (Bottini et al., 2007). Organically modified $20 \mathrm{~nm} \mathrm{SiO}_{2}$ with an incorporated hydrophobic photosensitizer (e.g. porphyrin) were tested for its toxicity levels with tumor cells and showed no apparent toxicity unless irradiated with light to product ROS (Ohulchanskyy et al., 2007). Generally, amorphous $\mathrm{SiO}_{2}$ nanoparticles are considered highly biocompatible and noncytotoxic unless engineered to be otherwise.

3.2.5. Iron oxide-Iron in the presence of an oxidant (e.g. air) will become iron oxide (i.e. rust). There are several phases of iron oxides which include Haematite $\left(\alpha-\mathrm{Fe}_{2} \mathrm{O}_{3}\right)$, Magnetite $\left(\mathrm{Fe}_{3} \mathrm{O}_{4}\right)$, Maghemite $\left(\gamma-\mathrm{Fe}_{2} \mathrm{O}_{3}\right), \beta-\mathrm{Fe}_{2} \mathrm{O}_{3}, \varepsilon-\mathrm{Fe}_{2} \mathrm{O}_{3}$, Wüstite $(\mathrm{FeO})$ (Cornell and Schwert-mann, 1996). Among them, magnetite $\left(\mathrm{Fe}_{3} \mathrm{O}_{4}\right)$ nanoparticles have been the subject of research for many years in hopes of using them for biomedical research (Bulte et al., 2001; Caruthers et al., 2007; Dunning et al., 2004; Gupta and Gupta, 2005; Mornet et al., 2004; Pankhurst et al., 2003; Simberg et al., 2007; Sykova and Jendelova, 2007; Thorek et al., 2006; Weissleder and Mahmood, 2001; Xu and Sun, 2007). Sub-10 $\mathrm{nm} \mathrm{Fe}_{3} \mathrm{O}_{4}$ nanoparticles have been particularly useful as a superparamagnetic MRI probe that can be made to target-specific cells and tissues inside the body. It is straightforward to synthesize iron oxides especially magnetite nanoparticles: iron salt, surfactant, base, solvent and heat. Compared to $\mathrm{TiO}_{2}$ and $\mathrm{SiO}_{2}$, iron oxides are partially soluble in acidic media containing chelating agents such as siderophores (Kraemer, 2004).

For this very reason, in vitro neurotoxicity of iron oxides was implicated by researchers from UCSD (Pisanic et al., 2007). In this study, iron oxide nanoparticles affected PC12 cells' ability to differentiate in response to nerve growth factors (NGF) in a concentration dependent manner. For instance, Western blotting revealed that growth associated protein GAP-43 level decreased dramatically when the NGF concentration went from 0.15 to $1.5 \mathrm{mM}$ then $15 \mathrm{mM}$ which alerted the researchers to re-evaluate their efforts in using iron oxide nanoparticles for neurobiological applications. Iron oxides are negatively charged in physiological $\mathrm{pH}$ conditions. This good example shows how surface chemistry and its electronic states control bioprocesses in a detrimental manner. Any use of nanotechnology in biological applications should accompany 
stringent biocompatibility studies of not only in short-term effects but also effects from chronic exposure. Case-by-case approach to probe nanotoxicology is a must especially when bioprocess control over neurological systems is strongly desired. Table 3 lists several good examples of research groups around the world that have researched into both in vitro and in vivo toxicology of iron oxides.

On a slightly different note, Ruoslahti and co-workers (Simberg et al., 2007) have utilized 50 $\mathrm{nm}$ iron oxide nanopaticles as tumor homing vehicles that has been conjugated to a tumor targeting peptide CREKA (Cys-Arg-Glu-Lys-Ala). CREKA allows the nanoparticle to recognize clotted plasma proteins and bind to vessel walls and tumor stroma. Interestingly, these nanoparticles accumulate in tumor vessels; induce blood clotting which increases binding sites for additional particles to home in to. This type of controlled and targeted toxicity is a new state-of-the-art use of iron oxide nanoparticles in comparison to their sole use as image contrast agents. It will be beneficial for the neuroscience community to bench mark such efforts from the cancer research community and follow the biological target based approaches and implement them to known targets in neurological disorders.

3.2.6. Cerium oxide: neuroprotecting agent- $-\mathrm{CeO}_{2}$ is a very potent oxidation catalyst which promotes chemical reactions such as $\mathrm{CO}$ oxidation in automobile catalytic converters (Guzman et al., 2005; Trovarelli, 1996). In the last few years, several works involving ceria nanoparticles on their ability to offer cellular level protection have been reported (Das et al., 2007; Niu et al., 2007; Schubert et al., 2006; Singh et al., 2006a). Nano-ceria nanoparticles prevented increases in reactive oxygen species (alternatively coined reactive oxygen intermediates) in vitro and in vivo. Light-induced degeneration of photoreceptor cells leading to vision loss was reduced. These findings suggest that therapeutics developed based on nano$\mathrm{CeO}_{2}$ may effectively decrease any ill effects arising from ROS related degeneration, diseases and ailments (Chen et al., 2006b). In an earlier study, radiation studies were done and it was found that normal cells pretreated with nano-ceria did not die where as untreated cancer cells did. The nature of these types of protective effect comes from the oxidation-reduction (redox) chemistry between $\mathrm{Ce}^{4+}$ and $\mathrm{Ce}^{3+}$ and the fact that the inorganic structure of ceria can tolerate defects via oxygen vacancies in $\mathrm{CeO}_{2-\chi}$ (Mogensen et al., 2000). Surface charge effects of nano-ceria were investigated in several different $\mathrm{pHs}$ and synthesis conditions. As expected, protein adsorption (e.g. BSA) increased as a function of zeta potential increase and negatively charged $\mathrm{CeO}_{2}$ internalized preferentially in cellular uptake experiments. Synthesis methods strongly affected the IEP of nano-ceria: microemulsion method gave 4.5 and hydrothermal method gave 9.5 (Patil et al., 2007). IEP differences arising from synthesis details being different might be a key issue when utilizing nanostructured materials for biological applications. Biological screening of cerium oxide with a focus in nanotoxicology has been conducted only within the last few years and we have summarized those efforts in Table 4.

3.2.7. Carbon materials-Among carbon-based materials, carbon nanotubes have been well utilized in recent biological applications. Excellent review papers already exist for CNT's (Dai, 2002; Dai et al., 2003; Harrison and Atala, 2007; Pagona and Tagmatarchis, 2006) and $\mathrm{C}_{60}$ fullerenes (Diederich and Gomez-Lopez, 1999; Fiorito et al., 2006; Hirsch, 1995; Jensen et al., 1996; Ke and Qiao, 2007; Prato, 1997; Satoh and Takayanag, 2006) so we will focus on new types of spherical and non-tubular forms of carbon that was developed for biological applications (Fig. 7). The first example is carbon nanohorns by Iijima and co-workers (Ajima et al., 2005; Isobe et al., 2006; Matsumura et al., 2007; Miyawaki et al., 2006; Murakami et al., 2004). Processed in a similar fashion as CNT's, researchers were able to synthesize high surface area carbon materials that have tube-like carbon sticking outward but in a spherical overall shape and are approximately $100 \mathrm{~nm}$ in size. Cytotoxic assays show practically no toxicity. The second one is carbon nanodots (sub-10 nm) which were strongly two-photon active and emit in the visible range (Cao et al., 2007). In vitro tests suggest that the carbon 
nanodots can be internalized into mammalian cells and fluorescent microscopy imaging was possible. A third recent class is (fluorescent) diamond nanoparticles (Fu et al., 2007; Yu et al., 2005) which were found to be noncytotoxic and were used as single-particle biomarkers on mammalian cells.

3.2.8. Zeolites and clays-Recent development in utilizing porous zeolite materials for biomedical application has focused on two main areas. One is in hemostatic agents which induces blood clotting upon treatment and the other in antibacterial agent development (Sakaguchi et al., 2005). Quikclot® (QC) developed by Z-Medica has been a key agent utilized by the military to reduce deaths in the field by blood loss. This agent is very effective but also induces local dehydration and causes in situ cauterization. Instead of zeolite based porous materials either mesoporous bioglass (Ostomel et al., 2006a,b) or clays (Baker et al., 2007) can be a highly effective blood clotting agent. Both of these materials, in fact, avoid causing burns to the user. A much more recent product, Quikclot Sport ${ }^{\circledR}$ Silver ${ }^{\mathrm{TM}}$, which incorporated silver in the matrix alleviated the negative factors in QC and Z-Medica now offers a burn-free, antibacterial dressing for external wounds (Z-Medica). This later examples clearly demonstrates how a single metal ion source can greatly affect the materials' overall interaction with biological systems such as the blood clotting cascade.

Tailoring inorganic nanostructures by their composition and surface electronics might further allow researchers to invent a porous system where one can control the rate of blood clotting by either engineering the isoelectric point (Ostomel et al., 2007; Sakaguchi et al., 2005) or by incorporating biologically relevant entities into the nanostructured base material (Ostomel et al., 2006c). In essence, there is no extensive mammalian toxicology study done on zeolites but their use as blood clotting agents and related clinical studies have proven that their use on animals and human beings are reasonable within the scope of allowed practices of medicine. We expect to see more work on blood clotting and antibacterial agents using zeolite and other types of porous metal oxides. Studying such controllable systems might offer insights into targeting internal head injuries and other types of internal wounds and clots and allow researchers to directly deal with such medical issues.

3.2.9. Metal and semiconductor nanoparticles-Utilization of metal and semiconductor nanoparticles in biomedical applications has been demonstrated very well by many research groups (Daniel and Astruc, 2004; Fu et al., 2005; Jun et al., 2006; Medintz et al., 2005; Michalet et al., 2005; Tang and Kotov, 2005). Reviews for these two classes of materials exist in multiples and we do not want to repeat what others have done. For metal nanoparticles such and $\mathrm{Au}$ and $\mathrm{Ag}$, however, we would like to introduce molecular imaging via (surface) plasmon resonance coupling (Campbell and Xia, 2007; Haes et al., 2004, $2005 \mathrm{a}, \mathrm{b})$.Aaron et al. have shown that $25-\mathrm{nm}$ gold nanoparticles when conjugated with antiEGF (epidermal growth factor) receptor monoclonal antibodies can be efficiently used as in vivo targeting agents for imaging cancer markers, specifically epidermal growth factor receptors. The Au nanoparticles results in a dramatic increase in signal contrast compared to other antibody-fluorescent dye targeting agents.

Semiconductor nanoparticles such as $\mathrm{CdSe} / \mathrm{ZnS}$ nanoparticles have been utilized heavily for bioimaging applications (Michalet et al., 2005). The biggest challenge with this type of material is the potential of high toxicological effect caused by heavy metal dissociation (Chang et al., 2006; Derfus et al., 2004; Kirchner et al., 2005; Sinani et al., 2003; Voura et al., 2004; Zhang et al., 2006). Many in vitro and in vivo toxicological studies were conducted and interesting studies have been done and in recent years the effect of nanoparticles on microbial species and in the environment has received notable attention (Adams et al., 2006; Bhattacharya and Gupta, 2005; Dreher, 2004; Guzman et al., 2006; Liu, 2006; Maynard and Kuempel, 2005; Wigginton et al., 2007). It is particularly interesting that certain microbial species interact extraordinarily 
with nanomaterials or in certain instances even synthesize nanostructured materials (Gericke and Pinches, 2006; He et al., 2007; Konishi et al., 2006, 2007; Marshall et al., 2006; Moreau et al., 2007; Shankar et al., 2003). Combining efforts from environmental and biological sciences not necessarily related to medicine could eventually help us understand how different biological systems react cooperatively or uncooperatively with certain types of nanostructured materials regardless of their overall size and content. Moreau et al. (2007), for instance, have shown that extracellular proteins from microbial species can promote biomineralization of metal-bearing nanoparticles and suggested that such an event can lead to limiting nanoparticulate dispersion in the environment.

\section{Nanomaterials for biomedical research: opportunities in neuroscience}

\subsection{Nanowires and patterned surfaces}

Patterned surfaces, particularly, created with PDMS (poly (dimethylsiloxane)) elastomer have been of high interest to many for cell attachment studies both for eukaryotic (Aizenberg et al., 1998; Chen et al., 1998, 2005; Kane et al., 1999; Mrksich and Whitesides, 1996; Takayama et al., 1999; Whitesides and Lamantia, 1995; Zhang et al., 1999) and prokaryotic (Weibel et al., 2007) systems (Fig. 8a). Whitesides and co-workers have shown that micro- and nanoscale patterns on flexible substrates can be excellent tools to study cell mechanics and function. In fact, multitudes of projects now involve the use of soft lithography techniques (based on cleanroom microtechnology used to make electronic materials and circuits) which allow facile creation of highly reproducible surface patterns and subsequent systematic analysis of biological systems. Jeon and co-workers at UC Irvine have successfully engineered lab-onchip systems (made out of PDMS and slide glass) which allow neuronal cell bodies to be spatially separated from the out-growing neurites and axons (Park et al., 2006; Taylor et al., 2005). Microtechnology have also been well utilized by Bhatia and co-workers at MIT to control cellular level microenvironments which allowed three-dimensional cell cultures and high-throughput screening of biomolecules such as extracellular matrix proteins possible (Albrecht et al., 2006; Flaim et al., 2005; Hui and Bhatia, 2007; Khetani and Bhatia, 2008; Underhill and Bhatia, 2007). Lithography techniques also allowed the development of lab-onchip devices (or platforms) which led to long-term low cell density (nano-liter volumes) postnatal rat primary hippocampal neuron cultures as demonstrated by Millet et al. (2007) at the University of Illinois. The June 2007 issue of Lab on a Chip journal published a special issue on 'Cell and Tissue Engineering in Microsystems' which covers a variety of research efforts involving cell biology investigation on microdevices and patterned surfaces (Bhatia and Chen, 2007) and with the advancement of single cell analysis techniques (Jo et al., 2007; Jurchen et al., 2005; Kruse and Sweedler, 2003; Monroe et al., 2005; Northen et al., 2007; Rubakhin et al., 2000, 2003; Rubakhin and Sweedler, 2007), long-term cell culture experiments with precisely controlled microenvironments can be done in a facile manner in conjunction with high resolution real-time analysis of cellular products.

Nanowires with sub-micron diameters have also been utilized to study cell biology. Yang and co-workers at UC Berkeley have recently reported that sub-100 nm (diameter) silicon nanowires ( $\mathrm{SiNW}$ ) can be integrated into live cells without causing detrimental affects (Kim et al., 2007c). Basically, they were allowed to grow mouse embryonic stem cells on the SiNW and also use them as nanoscale needles to deliver biological materials such as GFP (green fluorescent protein) plasmid (Fig. 8b) into cells. At almost the same time, Bertozzi and coworkers have reported the use of a modified nanosized AFM (atomic force microscopy) tip to favorably deliver fluorescent nanoparticles such as CdS (Chen et al., 2007)(Fig. 8c). The diameter of the AFM tip was sub-10 $\mathrm{nm}$ and it proved that length scales much smaller than the cell was very important for the survival and subsequent delivery of materials inside the cell. Making sub-micron patterns of biomolecules as well as functionalizing the sub-patterns with 
inorganic nanowires and nanopores which can incorporate biological materials will offer additional key functions to any device that may incorporate such sub-units. For neuroscience research, microdevices with sub-cellular (sub-micron) features, patterns, and functional surfaces can eventually aid in carrying out nanosurgeries to cells linked to the CNS and also in studying the interface that is created between neurons and neuronal implants in vitro and in vivo.

\subsection{Multifunctional nanoparticle}

Recent trends in nanoparticles engineered for biomedical applications involve nanoparticles having multiple components in the nanomaterial (Fig. 9). In most cases, as depicted in the schematic, a multifunctional nanoparticle system (MFNPS) would be comprised of four main components: a matrix which is few hundred nanometers in size or smaller, a magnetic domain (e.g. $\mathrm{Fe}_{3} \mathrm{O}_{4}$ ) for MR imaging, an optical probe (usually fluorescent such as FITC) for microscopy, and pores or functionality that allows the incorporation of a small molecule (i.e. therapeutic agent) or a biomolecule (i.e. antibody). MFNPSs can have four distinctive types. Type 1 is non-porous but spherical $\mathrm{SiO}_{2}$ based sub-100 nm nanoparticles with two or more components. Type 2 is sub-200 nm spherical nanoparticles that is either porous or can incorporate and, in time, release small molecules such as drug molecules. Type 3 is sub- $20 \mathrm{~nm}$ nanoparticles with functionalizable ligands or biomolecules stabilized (passivated) onto the nanoparticles and are, in most cases, first synthesized in organic conditions and then phase exchanged. Finally, type 4 is non-spherical nanoparticle systems that have multiple components such as fluorescent tags and antibodies. (Fig. 9) This last type 4 MFNPs will essentially have very different biological responses compared to spherical systems. According to a recent study by Discher and co-workers (Geng et al., 2007) showed that particle flow and subsequent delivery of drugs are affected by shape in vivo. Filament (non-spherical) type particles resided approximately ten times longer than spherical particles and due to their prolonged existence drug delivery was more effective as well. Cell uptake efficiencies also differed.

Multiple examples of MFNPS exist that have small molecule therapeutic agents incorporated (Josephson et al., 2002; Kim et al., 2006b, 2007a; Lee et al., 2004b, 2006c; Levy et al., 2002;

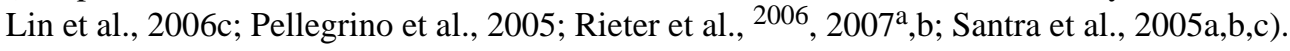
The overall theme for MFNPS is very straightforward but finding a balance between rationally designing the system and, at the same time, practically screening will be key issues in the development of MFNPS for biomedical application.

In contrast to inorganic based systems, biodegradable polymers such as poly(L-lactic acid) (PLLA), poly(lactide-co-glycolide) (PLGA), BSA (bovine serum albumin) have been in existence for a while now and is widely used for the controlled delivery of drugs and proteins in the form of microspheres or nanospheres (Giovagnoli et al., 2005; Ibrahim et al., 2005; Langer, 1990; Song et al., 1997; Suslick and Grinstaff, 1990; Wei et al., 2004, 2006; Yeo and Park, 2004). Based on these types of degradable polymeric systems, antibody conjugated magnetic PLGA nanoparticles were reported recently for the diagnosis and treatment of cancer (Yang et al., 2007). The drug molecule incorporated into this PLGA nanoparticle was doxorubicin (DOX) which is very similar in structure with minocycline (Choi et al., 2007)(Fig. 9) which has recently been shown to have potent anti-Alzheimer's disease effect. In fact, although not a multifunctional particle, Huperzine A was encapsulated in PLGA in its microspherical form and was used in the treatment of memory impaired rodents (Chu et al., 2007; Gao et al., 2007). Microemulsion methods have also been used to deliver pharmaceuticals, specifically metal chelators to treat CNS related diseases (Cui et al., 2005b). Veiseh et al. (2005) have reported that multifunctional nanoprobes which contained glioma cell targeting functions were also capable of being detected via MRI and fluorescent 
microscopy methods. This multifunctional nanoparticle is made up of iron oxide and poly (ethylene glycol) with dual functional groups.

With just single-component nanoparticles, researchers have used the nanoparticles to aid in their quest to find a cure for dementia related diseases such as Alzheimer's disease and Parkinson's disease. Nanostructured gold materials have been used to promote/suppress local protein aggregations such as $A \beta$ (Kogan et al., 2006). In an earlier study, silver nanoparticles were utilized to study the interaction between amyloid $\beta$-derived diffusible ligand (ADDL) and the anti-ADDL antibody (Haes et al., 2004, 2005a).

In summary, tailoring the size, contents, and surface electronic properties through chemistry and physical methods within sub-200 nm nanoparticles will be key factors in the quest of using MFNPS (multifunctional nanoparticles) for the treatment and diagnosis of brain related abnormalities. Many review papers (Cornford and Hyman, 1999; Liu et al., 2005a; Lockman et al., 2002; Roney et al., 2005) have been written in recent years that talk about size being a key issue in drug delivery to the brain past the blood—brain barrier (BBB). That is very true in cases where spherical morphologies are observed in the nanomaterials but it raises a big question about particles of different shapes such as carbon nanotubes (Geng et al., 2007). In addition, although not in the field of neuroscience, lessons learned from blood related research using inorganics (Baker et al., 2007; Boettcher et al., 2007; Ostomel et al., 2006a,b,c, 2007) might help to improve particle design, synthesis and final usage as therapeutic or diagnostic agents in CNS related disorders.

We would like to end this section by providing a table listing various multifunctional nanoparticles (shown in Fig. 9) that have been developed in the past several years. This table is aimed to give a straightforward component and characteristic analysis thus providing unfamiliar neuroscientists (or any other biologist) to pick and choose what they think might improve their current research. In majority of the cases, as outlined in Fig. 9, the particles are comprised of a matrix and two or more sub-components that can be detected using fluorescence microscopy or magnetic resonance imaging. The key structural differences arise from varying formulations among these three main contents but biological functions are more strongly affected by the surface chemistry which is not always straightforward to analyze. The ability to control the size and contents within a multifunctional nanoparticle system seems to have been explored to a much greater extent which focuses on bioimaging rather than actually using them to control specific biological functions. Expanding the state-of-the-art research represented in Table 5 to control bioprocesses involved in various biological systems and functions such as directing neuronal growth and influencing stem cell differentiation seems to be the next logical step in nanobiotechnology utilizing MFNPS.

\subsection{Nanoscale imaging}

Imaging techniques have improved dramatically over the years, especially the ones that involve nanometer level resolution. Electron microscopy (EM) have been well utilized in many science and engineering fields but such techniques involve the samples to be highly dehydrated since the imaging can only be done under vacuum (Allen et al., 2007; Graham and Orenstein, 2007; Kiseleva et al., 2007). Atomic force microscopy, however, has been the more samplefriendly technique for imaging nanoscale biological and bioinspired materials which is done under atmospheric pressure (Dufrene, 2008; Friedbacher et al., 1991; Hansma, 2001; Hansma et al., 1992, 1996, 1997). Another instrument that biologists and environmental scientists have increased usages of is the ESEM (environmental scanning electron microscope) which can analyze hydrated samples (Bogner et al., 2007; Muscariello et al., 2005; Priester et al., 2007) and is now frequently used to analyze biofilms. Fig. 10 shows characterization tools categorized by type of analysis based on composition (elemental), size (resolution) and type of biological sample analysis which can be linked to contents in Fig. 1. It is important to note that most of 
the high resolution instrumentation techniques require the samples to be under high vacuum which complicates the sample preparation process especially for biological and wet-samples; hence AFM is the method of choice when relatively unaltered (excluding the fixation process) sample imaging analysis is desirable. For instance, studying protein interactions on surfaces can be best done using AFM and when coupled with time and optical data, the dynamics of protein folding and unfolding can be imaged, tracked and analyzed. In fact, physical scientists have developed analysis platforms that couple together an AFM with a confocal microscope which is now commercially available (Blow, 2008).

Protein misfolding and formation of aggregations have been linked to several neurodegenerative diseases which include Parkinson's, Alzheimer's diseases and Down's syndrome (Bross and Gregersen, 2003). Research efforts focused on understanding the structural variables dictating the ultimate abnormalities linked with such diseases have been done using imaging techniques including AFM (Braga and Ricci, 2004). Suh and co-workers have recently shown that $\mathrm{A} \beta$ peptide agglomeration characteristics influence the proliferation and differentiation of murine adult neural stem cells (Heo et al., 2007). The nanoimaging technique which the researchers utilized was AFM as shown in Fig. 11a and d and under atmospheric pressure morphologically distinctive forms of $A \beta$ peptide are formed; oligomeric or fibrillar. Various other groups have utilized AFM to conduct morphological characterization studies related to amyloid beta peptide and other proteineous species linked to neurological disorders such as $\alpha$-synuclein and tau (Lyubchenko et al., 2006). Not only in biology but also synthetic inorganic nanomaterials can have distinctive morphologies as shown in Fig. 11b and e which are made up of essentially the same material (i.e. Ti and O). This is why associating structural factors to understand different outcomes in biological systems will be highly important when nanotechnology and biotechnology are adjoined together. For direct cell imaging, Lal et al. (1995) used AFM to image neurite outgrowth and cytoskeletal reorganization in realtime using rat fibroblast cells (NIH/3T3) and rat tumor cells (PC-12) in vitro. More recently, efforts of cell imaging using AFM have extended to other eukaryotic and prokaryotic species to reveal nanoscale features under ambient conditions (Dufrene, 2008; Kada et al., 2008).

Analyzing and understanding the toxic potentials of nanostructured beta amyloids vs. similar proteineous structures in microbial organisms (i.e. bacterial toxins) have been one of the latest developments in the efforts to understand the nature of structural and functional factors giving rise to unique but detrimental properties in the CNS (Fowler et al., 2007; Lashuel and Lansbury, 2006). Whether it is the fibrillar or oligomeric or porous (channel like) forms of $A \beta$ or $\alpha$ synuclein, the underling theme is that different nanostructures at different time-domains will affect neurogenesis in a dynamic and complex manner. As mentioned above, nanomaterials of metal oxides (Fig. 11b and e) can be engineered to mimic the structures of $A \beta$ (as shown in Fig. 11a and d) and have well-defined isoelectric points by utilizing constituent engineering via synthetic chemistry methods.

Biochemical and molecular biology analyses can be performed to further elucidate and understand the structural effects that different nanoparticles will have on living system (i.e. cells) at the sub-100 nm domain which is at a length scale where important cellular functions (i.e. transcription, translation) are carried out. However, as mentioned in Section 3.2, the level of understanding of association between cytotoxicity and structural and physicochemical properties of nanomaterials is still not well established. On top of this unresolved complexity, there are various examples and forms of protein aggregation and misfolding that occurs naturally that is linked with neurodegeneration so a step-wise and systemic (high) throughput approach (Shaw et al., 2008; Weissleder et al., 2005) will be helpful. Cellular level activities involving small ion and molecular trafficking (i.e. $\mathrm{Ca}^{2+}$ signaling and gene imaging in vivo) have received much attention as of late which focuses on nanometer level resolution and 
manipulation (Atanasijevic and Jasanoff, 2007; Atanasijevic et al., 2006; Palmer et al., 2004). As mentioned in Section 2.3, gene transcription has been imaged in the brain of mice after delivery of antisense nucleic acid decorated $15-20 \mathrm{~nm}$ superparamagnetic iron oxide nanoparticles (also fluorescent) in vivo using magnetic resonance imaging (Liu et al., 2007b; Masotti et al., 2008). Specific sequences for the antisense single-stranded phosphorothioatemodified oligodeoxynucleotides (sODNs) were complementary to $c$-fos and $\beta$-actin mRNA and avidinbiotin complexation method was crucial in the formation of the imaging probe. Coupling multiple analysis tools (Fig. 10) to establish a well-defined understanding of sub-100 $\mathrm{nm}$ activities associated with cell biology will be invaluable in the further development of nanobiotechnology.

\subsection{Gene delivery}

4.4.1. DNA based nanotechnology—DNA based nanotechnology, in many ways, has been one of the most heavily studied fields that involves the use and the creation of bioinspired materials for highly selective biosensing, nanoarchitecture engineering and nanoelectronics (Ito and Fukusaki, 2004; Lu and Liu, 2006, 2007; Seeman, 2005; Shamah et al., 2008;

Stoltenburg et al., 2007; Wernette et al., 2008). Biologically, nucleic acid delivery in vitro and in vivo has been well studied and lipid based gene delivery has become a common and essential methodology for neuroscientists and biologists. Transfection techniques, for mammalian cells, are primarily divided into non-viral and viral techniques and for many nanotech research groups investigating gene and drug delivery methodologies, the focus is on the non-viral particle based systems (Dobson, 2006; Labhasetwar, 2005; Li and Szoka, 2007) but increasing number of nanotech projects are investigating and manipulating viruses (Kovacs et al., 2007; Loo et al., 2007; Radloff et al., 2005; Sun et al., 2007).

For DNA delivery and utilization of DNA to study the dynamics of nanostructures, $\mathrm{Au}$ nanoparticles (Daniel and Astruc, 2004) and silica nanoparticles have been the choice of materials since there surface chemistries, physicochemical and optoelectronic properties are well established (Hench and West, 1990; Livage et al., 1988; Yan et al., 2007). Nucleic acid hybridization via base pairing (hydrogen bonding) and Au-thiol chemistry (Bain et al., 1989; Laibinis et al., 1991; Love et al., 2005), for the most part, offered a unique opportunity for investigating assembly of DNA functionalized gold nanoparticles which lead to the development of novel sensing technologies (Sassolas et al., 2008) for detecting small molecules (Liu and Lu, 2004b, 2006b; Liu et al., 2006), biomolecules (Cao et al., 2002; Hill et al., 2007; Lee et al., 2004a; Tansil and Gao, 2006) and metal ions (Liu and Lu, ${ }^{2003}$, 2004a, 2005, 2006a; Lu and Liu, 2007; Wernette et al., 2008) and nanoassembly/architecture projects (Mirkin, 2000; Park et al., 2004, 2008). Gene delivery using Au nanoparticles have well been demonstrated by Mirkin and co-workers on several occassions (Rosi et al., 2006; Seferos et al., 2007). Surface modified (multifunctional) silica nanoparticles have also been well utilized to deliver or detect DNAs (Bharali et al., 2005; Fuller et al., 2008; Gemeinhart et al., 2005; Klejbor et al., 2007; Kneuer et al., 2000a,b; Radu et al., 2004; Torney et al., 2007).

4.4.2. RNA interference-RNA interference (RNAi) and targeting the translation process which occurs in the cytosol, in rapid manner, paved the way to developing novel pathways to alter protein synthesis by the break down of mRNAs using small interfering RNAs (siRNAs) (Hannon, 2002). Along with siRNAs, microRNAs (miRNAs) are used by the genome of various organisms to carry out similar regulatory assignments which stops the translation process and recent research shows that miRNAs play critical roles in various neuronal pathways and stem cell biology (Hebert and De Strooper, 2007; Kosik, 2006; Kosik and Krichevsky, 2005). The use of chemistry and nanotechnology based tools in discovering new types of therapeutics based on non-viral carrier systems to deliver oligonucleotides into the cytosol to control the translation process have increased over the years (Baigude et al., 2007; Guo, 
2005; Heidel et al., 2007; Howard et al., 2006; Schiffelers et al., 2004; Yuan et al., 2006). In this section we would like to review some of the latest developments in the area of RNA interference and DNA delivery using synthetic nanomaterials from polymeric systems to inorganic systems (Fig. 12). The basic scheme, to highlight the state-of-the-art, is to penetrate the cell membrane, deliver binding agents, stop the target gene expression pathway but without damaging or killing the target cells.

Keller and researchers thoroughly investigated several different lipid based carrier systems (liposomal systems as mentioned in the paper) in relation to their protein downregulation efficiency and overall in vitro cell toxicity (Spagnou et al., 2004). Variety of commercially available lipid based nucleic acid delivery methods were investigated and compared for silencing the $\beta-$ Gal reporter gene in two cancer cell lines (HeLa and IGROV-1). The conclusion was that cationic lipid based delivery of plasmid DNA vs. siRNA have distinctive differences which warrant optimization of formulation for increased delivery efficiencies with low toxicities. Related research efforts involving the use of inorganic nanomaterials as gene delivery vehicles can readily utilize the nanotoxicology information reviewed (and tabulized) in this review in Section 3.

Rana and co-workers used a non-toxic and cationically charged poly(lysine) based dendrimer (spherical and oligomeric) nanoparticle with unsaturated hydrocarbon side chains (Baigude et al., 2007). The target gene was apoB and the mRNA expression silencing efficiency was, first, investigated in vitro using mouse liver cells (FL83B) and the results were comparable to Lipofectamine 2000 which is an industrial standard for gene delivery into cells. The in vivo silencing efficiency was highest at $1 \mathrm{mg} / \mathrm{kg}$ (reasonable dosage to be used in a therapeutic application) but did not increase past that concentration. Results of this study suggest that using both the cationically charged dendrimer and the chemically modified siRNA most efficiently silences the oligonucleotide.

Amine terminated or functionalized nanocarriers with PEGylated sub-units within the polymeric species were previously designed for complexation and delivery of siRNA to a human hepatoma cell line (HuH-7 cells) to knockdown transfected luciferage genes as well as the endogeneous Lamin A/C gene with excellent efficiencies (Itaka et al., 2004). Three amine variations were tested and compared; the dipropylene triamine moiety instilled supramolecular nanocarrier provided the best gene silencing ability. The other two were poly(L-lysine) and poly(3-dimethylamino)propyl aspartamide containing nanocarriers. The carrier with the dipropylene triamine has pKa values of 9.9 and 6.4 which allow facile siRNA complexation and sufficient buffering capabilities inside the endosome. In addition, the PEG unit within the dipropylene triamine nanocarrier allowed stable complexes to form with siRNAs even under $50 \%$ serum conditions and, in fact, the siRNA-nanocarrier complex even suppressed the endogeneous gene of Lamin A/C, a cytoskeletal protein abunduntly expressed in the cell. Kataoka and co-workers, furthermore, introduced a bioconjugate which covalently links siRNA with lactosylated PEG via an acid-labile linkage (size between 90-145 nm with approximately 36 PEG repeats) based on the fact that endosomes have a $\mathrm{pH}$ of about 5.5 and internalization of the conjugate will release the siRNA (Oishi et al., 2005, 2007). It is worth noting that PEGylation provides prolonged circulation time in vivo (Ogris et al., 1999) and has since emerged as one of the key functionalization tools for developing pharmaceuticals and nanobiocomposites for biomedical usages (Ballou et al., 2004; Brocchini et al., 2006; Harris and Chess, 2003; Kostiainen et al., 2007; Mishra et al., 2004; Petersen et al., 2002; Tang et al., 2003; Tu and Tirrell, 2004).

Inorganic based nanoparticles have also been utilized successfully for siRNA delivery and analysis. Bakalova and Ohba with fellow researchers utilized a synthetic inorganic core-shell and fluorescent nanoparticle made out of $\mathrm{CdSe} / \mathrm{ZnS}$ (quantum dots; QD) to multifunctionalize 
and screen for siRNA sequences. FRET (fluorescence resonance energy transfer) was the main tool for RNA analysis which was done after hybridizing the prepared QD-siRNA probe with Cy5 labeled target mRNA (isolated from K-562 leukemia cells) (Kubo et al., 2008). In an earlier study by Bhatia and co-workers, commercially available QDs that were PEGylated were further functionalized with tumor-homing peptides and siRNA and then used to silence gene (s) after targeting a specific cell (Derfus et al., 2007). Calcium phosphate nanoparticles (approximately $100 \mathrm{~nm}$ in size) were also effective in silencing the EGFP gene in HeLa cells in conjunction with siRNAs (Sokolova et al., 2007). In addition, gold nanoparticle (sized approximate $13 \mathrm{~nm}$ ) decorated with thiol-modified oligonucleotides (i.e. antisense and locked nucleic acid) were also shown to be very effective in entering the target cell and stopping a specific translational process in a non-toxic and controlled manner by the Mirkin group (Rosi et al., 2006; Seferos et al., 2007).

McKnight and co-workers have demonstrated a non-particle based system for RNA interference by using vertically aligned carbon nanofibers to deliver multiple genes (i.e. small hairpin RNA (shRNA) vector and YFP marker gene) which will silence the cyan fluorescent protein (CFP) synthesis in the presence of tetracycline in Chinese hamster ovary cells (CHOK1) (Mann et al., 2008). Previously, similar platform of materials were utilized to delivery DNA into living cells with good efficiency (McKnight et al., 2003; McKnight et al., 2004). This is very similar to the approach mentioned earlier in the review which highlights the work by Kim et al. (2007c) where GFP plasmid DNA is delivered using silicon nanowires.

RNA dumbbells or nanocircular RNAs (Fig. 12) consisting of 23 base pairs (firefly luciferase gene) and two 9-mer loops were designed and utilized as siRNA precursors after they were processed by the Dicer enzyme inside the cell (Abe et al., 2007). The stem-loop (design) combination allows the RNA dumbbells to be resistant to nucleases and provide a slow-acting RNAi profile. Design concept of this kind will allow the development of well-defined RNAi systems that will effectively silence gene expressions in a highly controllable and non-toxic manner.

\section{Conclusions}

Size means everything in linking nanotechnology together with biotechnology. Much biotechnology relies heavily on biomolecules such as proteins and DNA. Research in the field of neuroscience will definitely benefit with the advent of chemical and materials synthesis (e.g. multifunctional nanoparticle systems) that allows incorporation of these biomolecules to nanostructured inorganic and organic materials. The foremost areas are likely to involve bioimaging, biomedical-diagnostics, drug delivery, tissue engineering, and neuronal (network) systems studies. Most particularly, studies involving stem cell differentiation and transplantation, neural implants, targeted drug delivery with real-time monitoring capabilities, in vivo RNAi will prove very attractive. Multidisciplinary approaches will allow these sorts of projects to be successful research efforts and eventually lead to innovations that will ultimately help mankind. Close collaborations among researchers with different backgrounds will succeed best when nanostrutures are created and characterized by chemists and materials scientists and implementation of nanomaterials in specific biomedical applications are done by neuroscientists and clinicians. Most importantly, the roles of scientists trained and having experience working at the interface of biotechnology and nanotechnology will play increasingly important roles in the new wave of biomedical research and application. The scientific language and the way research is conducted, valued and evaluated between scientific disciplines have subtle differences which can slow down and even act as sources of deterrents in the road to a successful collaboration. Nanobiotechnology (or bionanotechnology) has advanced significantly now that synthesis and implication of applications need to be followed by practical and realistic usages. New advances, especially in neuroscience, will arise from 
systematic investigations starting from synthesis to application where the central efforts are probing and understanding events occurring at the nano-bio interface.

\title{
Acknowledgments
}

\begin{abstract}
We would like to thank Ms. Ah Ram Jang for her assistance in putting together the tables in Sections 4.2 and 3.2 and discussions related to the topic and Mr. Se Yun Kim for helpful discussions on several topics mentioned in this review paper. Electron microscope (EM) images (Figs. 1 and 11) were taken using FEI XL30 FE-SEM and FEI T20 TEM located in the California NanoSystems Institute (CNSI; now Elings Hall), UCSB. AFM images were taken at the Seoul National University (SNU) shared facilities. Single crystal X-ray diffraction on DHED was done at UIUC (Figs. 1 and 2). All illustrations were designed and created by Dr. Won Hyuk Suh with assistance from Ms. Hae Yeon Yi of the Graphic Design Program at UIUC. Financial support is from National Creative Research Initiative (CRI) Grant from Ministry of Education, Science and technology (MEST) and in part by BK 21 Human Life Sciences (Korea), NSF (CHE0315494, National Science Foundation, USA), NIH (HL 25934, National Institute of Health, USA), ONR (N00014-06-1-0145, Office of Naval Research, USA), NSF (DMR 02-33728, National Science Foundation, USA). Dr. Won Hyuk Suh would like to thank the Otis Williams Postdoctoral Fellowship in Bioengineering, UCSB (via Santa Barbara Fund) and the Drickamer Predoctoral Research Fellowship, UIUC for past, present, and future supports. Special thanks to Profs. Patricia Holden, Kenneth Kosik, Dennis Clegg, Herbert Waite, Matthew Tirrell, Norbert Reich, Dan Morse and Drs. Sherry Hikita, Brian Matsumoto, Min-Jeong Kye, Dong Soo Hwang, Na Xu, Kenneth Linberg, Shin-Sik Choi, Andrea Neals, and Ms. Allison Horst and Mr. John Priester for increasing the authors' understandings of the multiple nano-bio interfacial problems and research efforts they are involved in the UCSB campus. WHS also thanks the NIH sponsored CHOC/Burnham (now Scripps) human embryonic stem cell training course and the organizers, Dr. Philip Schwartz, Prof. Jean Loring, and the staff members.
\end{abstract}

\section{Abbreviations}

$3 \mathrm{~T} 3$

A-431 (or A431)

A549

$\mathrm{Ab}$

$\mathrm{A} \beta$

$\mathrm{AD}$

ADDL

AFM

AM

APP

AsPC-1

A*STAR

ATP

BAL

BBB

BD-AM

BEAS-2B

BET

$\beta$-Gal

bipy

BRL 3A derived from primary mouse embryonic fibroblast cells, 3-day transfer, inoculum $3 \times 10^{5}$ cells

human epithelial carcinoma cell line

human lung epithelial cell line

antibody

amyloid beta

Alzheimer's disease

amyloid $\beta$-derived diffusible ligand

atomic force microscopy

alveolar macrophages

amyloid precursor protein

human pancreatic cancer, epithelial cell line

Agency for Science Technology and Research

adenosine triphosphate

bronchoalveolar lavage

blood-brain barrier

primary alveolar macrophages from beagle dogs

human bronchial epithelial cell lines

Brunauer, Emmett and Teller

$\beta$-galactosidase

2,2'-Bipyridine

rat liver derived cell lines 


\begin{tabular}{|c|c|}
\hline BSA & bovine serum albumin \\
\hline $\mathrm{BV} 2$ (or BV-2) & murine brain microglia \\
\hline C57BL/6 & C57 black 6, most common inbred lab mouse \\
\hline CAT & catalase \\
\hline CBEN & Center for Biological and Environmental Nanotechnology \\
\hline CFP & cyan fluorescent protein \\
\hline $\mathrm{CFU}$ & colony forming unit \\
\hline CNS & central nervous system \\
\hline CNT & carbon nanotubes \\
\hline Colon-26 (or Colon 26) & murine rectum carcinoma cell line \\
\hline CREKA & Cys-Arg-Glu-Lys-Ala \\
\hline CRL8798 & normal breast epithelial cell line \\
\hline CRP & C-reactive protein \\
\hline DHED & dehydroevodiamine hydrochloride \\
\hline DLS & dynamic light scattering \\
\hline DMEM & Dulbecco's Modified Eagle’s Medium \\
\hline DMSO & dimethyl sulfoxide \\
\hline DNA & deoxyribonucleic acid \\
\hline DOX & doxorubicin \\
\hline $\mathrm{EC}$ & endothelial cell \\
\hline $\mathrm{EC}_{50}$ & half maximal effective concentration \\
\hline EGFP & enhanced GFP \\
\hline EM & electron microscopy \\
\hline ESEM & environmental SEM \\
\hline FITC & fluorescein isothiocyanate \\
\hline FRET & fluorescence resonance energy transfer \\
\hline GAP-43 & growth associated protein- 43 \\
\hline GAPDH & glyceraldehyde-3-phosphate dehydrogenase \\
\hline GFP & green fluorescent protein \\
\hline GPX (GPx or GSH-Px) & glutathione peroxidase \\
\hline GR & glutathione reductase \\
\hline GSH & glutathione \\
\hline H\&E staining & hematoxylin and eosin staining \\
\hline HA & hydroxyapatite \\
\hline HAEC & human aortic endothelial cell \\
\hline HEK293 & human embryonic kidney 293 cells \\
\hline
\end{tabular}




\begin{tabular}{|c|c|}
\hline HeLa & human cervical cancer cell line derived from Henrietta Lacks \\
\hline HER & human epidermal growth factor receptor \\
\hline hMSC & human mesenchymal stem cell \\
\hline HPRT & hypoxanthine-guanine phosphoribosyltransferase \\
\hline HRTEM & high resolution transmission electron microscope \\
\hline HT-1080 (or HT1080) & human fibrosarcoma cell line \\
\hline HT-22 (or HT22) & mouse hippocampal nerve cell line \\
\hline IACUC & Institutional Animal Care and Use Committees \\
\hline IBN & Institute of Bioengineering and Nanotechnology \\
\hline $\mathrm{ICON}$ & International Council on Nanotechnology \\
\hline ICP-MS & inductively coupled plasma mass spectrometry \\
\hline IEP & isoelectric point \\
\hline IMN & immuno-magnetic nanoparticle \\
\hline ISI & Institute for Scientific Information \\
\hline IUPAC & International Union of Pure and Applied Chemistry \\
\hline J774A.1 & murine macrophage \\
\hline Jurkat & human T lymphocyte cell line \\
\hline K-562 (or K562) & human myelogenous leukemia cell line \\
\hline L929 & murine fibroblast \\
\hline LBNL & Lawrence Berkeley National Laboratory \\
\hline LDH & lactate dehydrogenase \\
\hline $\mathrm{LD}_{50}$ & lethal dose for $50 \%$ of population \\
\hline LPO & lipid peroxidation \\
\hline $\mathrm{MCF}$ & mesocellular siliceous foam \\
\hline $\mathrm{MCF}-7$ & human breast carcinoma cell line \\
\hline MCM-41 & Mobil Catalytic Material number 41 \\
\hline MCP-1 & monocyte chemoattractant protein \\
\hline MDA & malondialdehyde \\
\hline MFNPS & multifunctional nanoparticle system \\
\hline MG63 & osteoblast-like cells \\
\hline miRNA & microRNA \\
\hline $\mathrm{MN}$ & micronuclei \\
\hline MOF & metal-organic framework \\
\hline MR & magnetic resonance \\
\hline MRC-9 & human lung fibroblast \\
\hline MRI & magnetic resonance imaging \\
\hline
\end{tabular}




\begin{tabular}{|c|c|}
\hline mRNA & messenger RNA \\
\hline MDA-MB-231 & human metastatic breast cancer cell \\
\hline MSDS & Materials Safety And Data Sheet \\
\hline MSTO & human mesothelioma \\
\hline MTT & $\begin{array}{l}\text { (3-(4,5-dimethylthiazol-2-yl)-2,5-diphenyltetrazolium bromide) } \\
\text { assay }\end{array}$ \\
\hline MWCNT & multi-walled carbon nanotube \\
\hline N/A & not available \\
\hline NCI & National Cancer Institute \\
\hline $\mathrm{NCL}$ & Nanotechnology Characterization Laboratory \\
\hline NGF & nerve growth factor \\
\hline $\mathrm{NIH}$ & National Institute of Health \\
\hline OECD & Organisation for Economic Co-operation and Development \\
\hline ORMOSIL & organically modified silica or silicate \\
\hline PAA & poly(aspartic acid) \\
\hline PANC-1 & human pancreatic carcinoma cell line \\
\hline PBS & phosphate buffer saline \\
\hline $\mathrm{PC} 12$ & $\begin{array}{l}\text { cancer cell line derived from a pheochromocytoma of the rat } \\
\text { adrenal medulla }\end{array}$ \\
\hline PDMS & poly(dimethylsiloxane) \\
\hline PEG & polyethylene glycol \\
\hline PEI & polyethyleneimine \\
\hline PLGA & poly(lactide-co-glycolide) \\
\hline PLLA & poly(L-lactic acid) \\
\hline PM & particulate matter \\
\hline $\mathrm{ppb}$ & parts per billion \\
\hline ppm & parts per million \\
\hline QC & Quikclot@ \\
\hline QD & quantum dot \\
\hline RAW164 & murine macrophage cell line \\
\hline RAW 264.7 & mouse leukemia macrophage cell line \\
\hline $\mathrm{RBC}$ & red blood cell \\
\hline RIF-1 & murine fibroblastic sarcoma cell line \\
\hline RNA & ribonucleic acid \\
\hline RNAi & RNA interference \\
\hline ROS & reactive oxygen species \\
\hline SBA-15 & Santa Barbara Amorphous 15 \\
\hline
\end{tabular}




\begin{tabular}{|c|c|}
\hline SBF & simulated body fluid \\
\hline SCE & sister-chromatid exchange \\
\hline SEM & scanning electron microscope \\
\hline SH-SY5Y & a third generation human neuroblastoma derived from SH-SY5 \\
\hline SiNW & silicon nanowires \\
\hline siRNA & small interfering RNA \\
\hline SMMC-7721 & human hepatoma (liver cancer) cell line \\
\hline SOD & superoxide dismutase \\
\hline SPIO & superparamagnetic inorganic or iron oxides \\
\hline SPION & superparamagnetic inorganic or iron oxide nanoparticle \\
\hline SRB & sulforhodamine B assay \\
\hline SWCNT & single-walled carbon nanotube \\
\hline TEM & transmission electron microscope \\
\hline TEOS & tetraethyl orthosilicate \\
\hline THB-1 & human alveolar macrophage \\
\hline THP-1 (or THP1) & human acute monocytic leukemia cell line \\
\hline TNF- $\alpha$ & tumor necrosis factor-alpha \\
\hline TUNEL & $\begin{array}{l}\text { terminal uridine deoxynucleotidyl transferase dUTP nick end } \\
\text { labeling }\end{array}$ \\
\hline U297 & human lymphoblast \\
\hline UF & ultrafine \\
\hline USPIO & ultrasmall superparamagnetic iron oxide \\
\hline UV & ultraviolet \\
\hline VMD & visual molecular dynamics \\
\hline WIL2-NS & human B-cell lymphoblastoid cell line \\
\hline WSIO & water-soluble superparamagnetic iron oxides \\
\hline WST-1 & $\begin{array}{l}\text { water-soluble tetrazolium number 1, (2-(4-iodophenyl)-3-(4- } \\
\text { nitrophenyl)-5-(2,4-disulfophenyl)-2H-tetrazolium) assay }\end{array}$ \\
\hline WT & wild type \\
\hline XPS & X-ray photoelectron spectroscopy \\
\hline XTT & $\begin{array}{l}\text { (2,3-bis-(2-methoxy-4-nitro-5-sulfophenyl)-2H-tetrazolium-5- } \\
\text { carboxanilide) }\end{array}$ \\
\hline YFP & yellow fluorescent protein \\
\hline
\end{tabular}

\section{References}

Aaron J, Nitin N, Travis K, Kumar S, Collier T, Park SY, Jose-Yacaman M, Coghlan L, Follen M, Richards-Kortum R, Sokolov K. Plasmon resonance coupling of metal nanoparticles for molecular imaging of carcinogenesis in vivo. J. Biomed. Opt 2007;12:034007. [PubMed: 17614715]

Prog Neurobiol. Author manuscript; available in PMC 2010 February 1. 
Abe N, Abe H, Ito Y. Dumbbell-shaped nanocircular RNAs for RNA interference. J. Am. Chem. Soc 2007;129:15108-15109. [PubMed: 18001025]

Adams LK, Lyon DY, Alvarez PJJ. Comparative eco-toxicity of nanoscale $\mathrm{TiO}_{2}, \mathrm{SiO}_{2}$, and $\mathrm{ZnO}$ water suspensions. Water Res 2006;40:3527-3532. [PubMed: 17011015]

Afaq F, Abidi P, Matin R, Rahman Q. Activation of alveolar macrophages and peripheral red blood cells in rats exposed to fibers/particles. Toxicol. Lett 1998a;99:175-182. [PubMed: 9862283]

Afaq F, Abidi P, Matin R, Rahman Q. Cytotoxicity, pro-oxidant effects and antioxidant depletion in rat lung alveolar macrophages exposed to ultrafine titanium dioxide. J. Appl. Toxicol 1998b;18:307-312. [PubMed: 9804429]

Ahn SH, Jeon SH, Tsuruo T, Shim CK, Chung SJ. Pharmacokinetic characterization of dehydroevodiamine in the rat brain. J. Pharmacol. Sci 2004;93:283-292.

Aizenberg J, Black AJ, Whitesides GM. Controlling local disorder in self-assembled monolayers by patterning the topography of their metallic supports. Nature 1998;394:868-871.

Ajima K, Yudasaka M, Murakami T, Maigne A, Shiba K, Iijima S. Carbon nanohorns as anticancer drug carriers. Mol. Pharmaceutics 2005;2:475-480.

Akerman ME, Chan WCW, Laakkonen P, Bhatia SN, Ruoslahti E. Nanocrystal targeting in vivo. Proc. Natl. Acad. Sci. U.S.A 2002;99:12617-12621. [PubMed: 12235356]

Alam HB, Burris D, DaCorta JA, Rhee P. Hemorrhage control in the battlefield: role of new hemostatic agents. Milit. Med 2005;170:63-69.

Albrecht DR, Underhill GH, Wassermann TB, Sah RL, Bhatia SN. Probing the role of multicellular organization in three-dimensional microenvironments. Nat. Methods 2006;3:369-375. [PubMed: 16628207]

Alfredsson V, Keung M, Monnier A, Stucky GD, Unger KK, Schuth F. High-resolution transmission electron-microscopy of mesoporous MCM-41 type materials. J. Chem. Soc. -Chem. Commun 1994:921-922.

Allen TD, Rutherford SA, Murray S, Sanderson HS, Gardiner F, Kiseleva E, Goldberg MW, Drummond SP. A protocol for isolating Xenopus oocyte nuclear envelope for visualization and characterization by scanning electron microscopy (SEM) or transmission electron microscopy (TEM). Nat. Protoc 2007;2:1166-1172. [PubMed: 17546011]

Allen TM, Cullis PR. Drug delivery systems: entering the mainstream. Science 2004;303:1818-1822. [PubMed: 15031496]

Arap W, Pasqualini R, Ruoslahti E. Cancer treatment by targeted drug delivery to tumor vasculature in a mouse model. Science 1998;279:377-380. [PubMed: 9430587]

Arbab AS, Bashaw LA, Miller BR, Jordan EK, Bulte JWM, Frank JA. Intracytoplasmic tagging of cells with ferumoxides and transfection agent for cellular magnetic resonance imaging after cell transplantation: methods and techniques. Transplantation 2003;76:1123-1130. [PubMed: 14557764]

Atanasijevic T, Jasanoff A. Preparation of iron oxide-based calcium sensors for MRI. Nat. Protoc 2007;2:2582-2589. [PubMed: 17948001]

Atanasijevic T, Shusteff M, Fam P, Jasanoff A. Calcium-sensitive MRI contrast agents based on superparamagnetic iron oxide nanoparticles and calmodulin. Proc. Natl. Acad. Sci. U.S.A 2006;103:14707-14712. [PubMed: 17003117]

Baigude H, McCarroll J, Yang CS, Swain PM, Rana TM. Design and creation of new nanomaterials for therapeutic RNAi. ACS Chem. Biol 2007;2:237-241. [PubMed: 17432823]

Bain CD, Troughton EB, Tao YT, Evall J, Whitesides GM, Nuzzo RG. Formation of monolayer films by the spontaneous assembly of organic thiols from solution onto gold. J. Am. Chem. Soc 1989;111:321-335.

Baker SE, Sawvel AM, Zheng N, Stucky GD. Controlling bioprocesses with inorganic surfaces: layered clay hemostatic agents. Chem. Mater 2007;19:4390-4392.

Baker SE, Sawvel AM, Fan J, Shi Q, Strandwitz NC, Stucky GD. Blood clot initiation by mesocellular foams: dependence on nanopore size and enzyme immobilization. Langmuir 2008;24:14254-14260. [PubMed: 19053630]

Balbus JM, Maynard AD, Colvin VL, Castranova V, Daston GP, Denison RA, Dreher KL, Goering PL, Goldberg AM, Kulinowski KM, Monteiro-Riviere NA, Oberdorster G, Omenn GS, Pinkerton KE, Ramos KS, Rest KM, Sass JB, Silbergeld EK, Wong BA. Meeting report: hazard assessment for 
nanoparticles—report from an interdisciplinary workshop. Environ. Health Perspect 2007;115:16541659. [PubMed: 18007999]

Ballou B, Lagerholm BC, Ernst LA, Bruchez MP, Waggoner AS. Non-invasive imaging of quantum dots in mice. Bioconj. Chem 2004;15:79-86.

Barone PW, Baik S, Heller DA, Strano MS. Near-infrared optical sensors based on single-walled carbon nanotubes. Nat. Mater 2005;4:86-92. [PubMed: 15592477]

Beck JS, Vartuli JC, Roth WJ, Leonowicz ME, Kresge CT, Schmitt KD, Chu CTW, Olson DH, Sheppard EW, McCullen SB, Higgins JB, Schlenker JL. A new family of mesoporous molecular-sieves prepared with liquid-crystal templates. J. Am. Chem. Soc 1992;114:10834-10843.

Bergna, HE. Colloid Chemistry of Silica. Vol. vol. 234. American Chemical Society; 1994. Colloid chemistry of silica. An overview. DuPont, Wilmington, DE, USA. Advances in Chemistry Series; $p$. 1-47.CODEN: ADCSAJ, ISSN: 0065-2393

Manufactured Nanoparticle Health and Safety Disclosure - Berkeley Ordanance. 2006. www.calcupa.net/programs/business/Berkeley_Ordinance.pdf

Berman HM, Westbrook J, Feng Z, Gilliland G, Bhat TN, Weissig H, Shindyalov IN, Bourne PE. The protein data bank. Nucleic Acids Res 2000;28:235-242. [PubMed: 10592235]

Bharali DJ, Klejbor I, Stachowiak EK, Dutta P, Roy I, Kaur N, Bergey EJ, Prasad PN, Stachowiak MK. Organically modified silica nanoparticles: a nonviral vector for in vivo gene delivery and expression in the brain. Proc. Natl. Acad. Sci. U.S.A 2005;102:11539-11544. [PubMed: 16051701]

Bhatia SN, Chen C. Special issue on cell and tissue engineering in microsystems. Lab Chip 2007;7:6661666.

Bhattacharya D, Gupta RK. Nanotechnology and potential of microorganisms. Crit. Rev. Biotechnol 2005;25:199-204. [PubMed: 16419617]

Blow N. Nanotechnology: could it be a small world after all? Nature 2008;452:901-906. [PubMed: 18421356]

Blumen SR, Cheng K, Ramos-Nino ME, Taatjes DJ, Weiss DJ, Landry CC, Mossman BT. Unique uptake of acid-prepared mesoporous spheres by lung epithelial and mesothelioma cells. Am. J. Respir. Cell Mol. Biol 2007;36:333-342. [PubMed: 17038662]

Boettcher SW, Fan J, Tsung CK, Shi QH, Stucky GD. Harnessing the sol—gel process for the assembly of non-silicate mesostructured oxide materials. Acc. Chem. Res 2007;40:784-792. [PubMed: 17461540]

Bogner A, Jouneau PH, Thollet G, Basset D, Gauthier C. A history of scanning electron microscopy developments: towards “wet-STEM” imaging. Micron 2007;38:390-401. [PubMed: 16990007]

Borm P, Klaessig FC, Landry TD, Moudgil B, Pauluhn J, Thomas K, Trottier R, Wood S. Research strategies for safety evaluation of nanomaterials. Part V. Role of dissolution in biological fate and effects of nanoscale particles. Toxicol. Sci 2006;90:23-32. [PubMed: 16396841]

Borm PJA, Kreyling W. Toxicological hazards of inhaled nanoparticles-potential implications for drug delivery. J. Nanosci. Nanotech 2004;4:521-531.

Bottini M, Cerignoli F, Mills DM, D’Annibale F, Leone M, Rosato N, Magrini A, Pellecchia M, Bergamaschi A, Mustelin T. Luminescent silica nanobeads: characterization and evaluation as efficient cytoplasmatic transporters for T-lymphocytes. J. Am. Chem. Soc 2007;129:7814-7823. [PubMed: 17542582]

Bourrinet P, Bengele HH, Bonnemain B, Dencausse A, Idee JM, Jacobs PM, Lewis JM. Preclinical safety and pharmacokinetic profile of ferumoxtran-10, an ultrasmall superparamagnetic iron oxide magnetic resonance contrast agent. Invest. Radiol 2006;41:313-324. [PubMed: 16481915]

Braga, PC.; Ricci, D. Atomic Force Microscopy: Biomedical Methods and Applications. Humana Press; Totowa, NJ: 2004.

Brocchini S, Balan S, Godwin A, Choi JW, Zloh M, Shaunak S. PEGylation of native disulfide bonds in proteins. Nat. Protoc 2006;1:2241-2252. [PubMed: 17406463]

Bross, P.; Gregersen, N. Protein Misfolding and Disease: Principles and Protocols. Humana Press; Totowa, NJ: 2003.

Brunner TJ, Wick P, Manser P, Spohn P, Grass RN, Limbach LK, Bruinink A, Stark WJ. In vitro cytotoxicity of oxide nanoparticles: comparison to asbestos, silica, and the effect of particle solubility. Environ. Sci. Tech 2006;40:4374-4381. 
Bulte JWM, Douglas T, Witwer B, Zhang SC, Strable E, Lewis BK, Zywicke H, Miller B, van Gelderen P, Moskowitz BM, Duncan ID, Frank JA. Magnetodendrimers allow endosomal magnetic labeling and in vivo tracking of stem cells. Nat. Biotechnol 2001;19:1141-1147. [PubMed: 11731783]

Burghard M. Carbon nanotubes by quantitative solid-state conversion of an organometallic precursor. Angew. Chem. Int. Ed 2003;42:5929-5930.

Campbell CT. Ultrathin metal films and particles on oxide surfaces: structural, electronic and chemisorptive properties. Surf. Sci. Rep 1997;27:1-111.

Campbell DJ, Olson JA, Calderon CE, Doolan PW, Mengelt EA, Ellis AB, Lisensky GC. Chemistry with refrigerator magnets: from modeling of nanoscale characterization to composite fabrication. J. Chem. Educ 1999;76:1205-1211.

Campbell DJ, Xia Y. Plasmons: why should we care? J. Chem. Educ 2007;84:91-96.

Candler PM, Dale RC. Three cases of central nervous system complications associated with Mycoplasma pneumoniae. Pediatr. Neurol 2004;31:133-138. [PubMed: 15301835]

Cao L, Wang X, Meziani MJ, Lu FS, Wang HF, Luo PJG, Lin Y, Harruff BA, Veca LM, Murray D, Xie SY, Sun YP. Carbon dots for multiphoton bioimaging. J. Am. Chem. Soc 2007;129:11318-11319. [PubMed: 17722926]

Cao YWC, Jin RC, Mirkin CA. Nanoparticles with Raman spectroscopic fingerprints for DNA and RNA detection. Science 2002;297:1536-1540. [PubMed: 12202825]

Carrado KA, Macha SM, Tiede DM. Effects of surface functionalization and organo-tailoring of synthetic layer silicates on the immobilization of cytochrome c. Chem. Mater 2004;16:2559-2566.

Carrero-Sanchez JC, Elias AL, Mancilla R, Arrellin G, Terrones H, Laclette JP, Terrones M. Biocompatibility and toxicological studies of carbon nanotubes doped with nitrogen. Nano Lett 2006;6:1609-1616. [PubMed: 16895344]

Caruthers SD, Wickline SA, Lanza GM. Nanotechnological applications in medicine. Curr. Opin. Biotechnol 2007;18:26-30. [PubMed: 17254762]

Casserly G, Barry T, Tourtellotte WW, Hogan EL. Absence of mycoplasma-specific DNA sequence in brain, blood and CSF of patients with multiple sclerosis (MS): a study by PCR and real-time PCR. J. Neurol. Sci 2007;253:48-52. [PubMed: 17234214]

Cengelli F, Maysinger D, Tschudi-Monnet F, Montet X, Corot C, Petri-Fink A, Hofmann H, JuilleratJeanneret L. Interaction of functionalized superparamagnetic iron oxide nanoparticles with brain structures. J. Pharmacol. Exp. Ther 2006;318:108-116. [PubMed: 16608917]

Chai GS, Yoon SB, Yu JS, Choi JH, Sung YE. Ordered porous carbons with tunable pore sizes as catalyst supports in direct methanol fuel cell. J. Phys. Chem. B 2004;108:7074-7079.

Chan KC, Patri AK, Veenstra TD, McNeil SE, Issaq HJ. Analysis of fullerene-based nanomaterial in serum matrix by CE. Electrophoresis 2007;28:1518-1524. [PubMed: 17447247]

Chang E, Thekkek N, Yu WW, Colvin VL, Drezek R. Evaluation of quantum dot cytotoxicity based on intracellular uptake. Small 2006;2:1412-1417. [PubMed: 17192996]

Chang JS, Chang KLB, Hwang DF, Kong ZL. In vitro cytotoxicitiy of silica nanoparticles at high concentrations strongly depends on the metabolic activity type of the cell line. Environ. Sci. Tech 2007;41:2064-2068.

Charache P, Macleod CM, White P. Effects of silicate polymers on erythrocytes in presence and absence of complement. J. Gen. Physiol 1962;45:1117-1143. [PubMed: 13878239]

Chen CS, Jiang XY, Whitesides GM. Microengineering the environment of mammalian cells in culture. MRS Bull 2005;30:194-201.

Chen CS, Mrksich M, Huang S, Whitesides GM, Ingber DE. Micropatterned surfaces for control of cell shape, position, and function. Biotechnol. Prog 1998;14:356-363. [PubMed: 9622515]

Chen HW, Su SF, Chien CT, Lin WH, Yu SL, Chou CC, Chen JJW, Yang PC. Titanium dioxide nanoparticles induce emphysema-like lung injury in mice. FASEB J 2006a;20:2393-2395. [PubMed: 17023518]

Chen JP, Patil S, Seal S, McGinnis JF. Rare earth nanoparticles prevent retinal degeneration induced by intracellular peroxides. Nat. Nanotechnol 2006b;1:142-150. [PubMed: 18654167]

Chen X, Kis A, Zettl A, Bertozzi CR. A cell nanoinjector based on carbon nanotubes. Proc. Natl. Acad. Sci. U.S.A 2007;104:8218-8222. [PubMed: 17485677] 
Chen XC, Chang LJ. Mycoplasma-mediated alterations of in vitro generation and functions of human dendritic cells. J. Biomed. Sci 2005;12:31-46. [PubMed: 15864737]

Choi JS, Jun YW, Yeon SI, Kim HC, Shin JS, Cheon J. Biocompatible heterostructured nanoparticles for multimodal biological detection. J. Am. Chem. Soc 2006;128:15982-15983. [PubMed: 17165720]

Choi Y, Kim H-S, Shin KY, Kim E-M, Kim M, Kim H-S, Park CH, Jeong YH, Yoo J, Lee J-P, Chang K-A, Kim S, Suh Y-H. Minocycline attenuates neuronal cell death and improves cognitive impairment in Alzheimer's disease models. Neuropsychopharmacology 2007;32:2393-2404. [PubMed: 17406652]

Chowdhury EH, Akaike T. Bio-functional inorganic materials: an attractive branch of gene-based nanomedicine delivery for 21st century. Curr. Gene Ther 2005;5:669-676. [PubMed: 16457655]

Chu DF, Tian JW, Liu WH, Li Z, Li YX. Poly(lactic-co-glycolic acid) microspheres for the controlled release of huperzine A: in vitro and in vivo studies and the application in the treatment of the impaired memory of mice. Chem. Pharm. Bull 2007;55:625-628. [PubMed: 17409558]

Chung TH, Wu SH, Yao M, Lu CW, Lin YS, Hung Y, Mou CY, Chen YC, Huang DM. The effect of surface charge on the uptake and biological function of mesoporous silica nanoparticles 3T3-L1 cells and human mesenchymal stem cells. Biomaterials 2007;28:2959-2966. [PubMed: 17397919]

Cobo F, Cortes JL, Cabrera C, Nieto A, Concha A. Microbiological contamination in stem cell cultures. Cell Biol. Int 2007;31:991-995. [PubMed: 17452110]

Cobo F, Stacey GN, Hunt C, Cabrera C, Nieto A, Montes R, Cortes JL, Catalina P, Barnie A, Concha A. Microbiological control in stem cell banks: approaches to standardisation. Appl. Microbiol. Biotech 2005;68:456-466.

Colvin VL. The potential environmental impact of engineered nanomaterials. Nat. Biotechnol 2003;21:1166-1170. [PubMed: 14520401]

Corma A. From microporous to mesoporous molecular sieve materials and their use in catalysis. Chem. Rev 1997;97:2373-2419. [PubMed: 11848903]

Cornell, RM.; Schwertmann, U. The Iron Oxides: Structure, Properties, Reactions, Occurrence and Uses. VCH, Weinheim; New York: 1996.

Cornford EM, Hyman S. Blood-brain barrier permeability to small and large molecules. Adv. Drug Deliv. Rev 1999;36:145-163. [PubMed: 10837713]

Cui DX, Tian FR, Ozkan CS, Wang M, Gao HJ. Effect of single wall carbon nanotubes on human HEK293 cells. Toxicol. Lett 2005a;155:73-85. [PubMed: 15585362]

Cui ZR, Lockman PR, Atwood CS, Hsu CH, Gupte A, Allen DD, Mumper RJ. Novel D-penicillamine carrying nanoparticles for metal chelation therapy in Alzheimer's and other CNS diseases. Eur. J. Pharm. Biopharm 2005b;59:263-272. [PubMed: 15661498]

Cushing BL, Kolesnichenko VL, O’Connor CJ. Recent advances in the liquid-phase syntheses of inorganic nanoparticles. Chem. Rev 2004;104:3893-3946. [PubMed: 15352782]

Center for Biological and Environmental Nanotechnology (CBEN). http://cben.rice.edu/

Dai HJ. Carbon nanotubes: synthesis, integration, and properties. Acc. Chem. Res 2002;35:1035-1044. [PubMed: 12484791]

Dai LM, He PG, Li SN. Functionalized surfaces based on polymers and carbon nanotubes for some biomedical and optoelectronic applications. Nanotechnology 2003;14:1081-1097.

Daniel MC, Astruc D. Gold nanoparticles: assembly, supramolecular chemistry, quantum-size-related properties, and applications toward biology, catalysis, and nanotechnology. Chem. Rev 2004;104:293-346. [PubMed: 14719978]

Das M, Patil S, Bhargava N, Kang JF, Riedel LM, Seal S, Hickman JJ. Auto-catalytic ceria nanoparticles offer neuroprotection to adult rat spinal cord neurons. Biomaterials 2007;28:1918-1925. [PubMed: 17222903]

Daxboeck F. Mycoplasma pneumoniae central nervous system infections. Curr. Opin. Neurol 2006;19:374-378. [PubMed: 16914976]

Daxboeck F, Khanakah G, Bauer C, Stadler M, Hofmann H, Stanek G. Detection of Mycoplasma pneumoniae in serum specimens from patients with mycoplasma pneumonia by PCR. Int. J. Med. Microbiol 2005;295:279-285. [PubMed: 16128402] 
Daxboeck F, Krause R, Wenisch C. Laboratory diagnosis of Mycoplasma pneumoniae infection. Clin. Microbiol. Infect 2003;9:263-273. [PubMed: 12667235]

Decker M. Novel inhibitors of acetyl- and butyrylcholinesterase derived from the alkaloids dehydroevodiamine and rutaecarpine. Eur. J. Med. Chem 2005;40:305-313. [PubMed: 15725500]

Delatte NJ. Lessons from Roman cement and concrete. J. Prof. Issues Eng. Educ. Pract 2001;127:109115.

Derfus AM, Chan WCW, Bhatia SN. Probing the cytotoxicity of semiconductor quantum dots. Nano Lett 2004;4:11-18.

Derfus AM, Chen AA, Min DH, Ruoslahti E, Bhatia SN. Targeted quantum dot conjugates for siRNA delivery. Bioconj. Chem 2007;18:1391-1396.

Diebold U. The surface science of titanium dioxide. Surf. Sci. Rep 2003;48:53-229.

Diederich F, Gomez-Lopez M. Supramolecular fullerene chemistry. Chem. Soc. Rev 1999;28:263-277.

Dobrovolskaia MA, McNeil SE. Immunological properties of engineered nanomaterials. Nat. Nanotechnol 2007;2:469-478. [PubMed: 18654343]

Dobson J. Gene therapy progress and prospects: magnetic nanoparticle-based gene delivery. Gene Ther 2006;13:283-287. [PubMed: 16462855]

Donaldson K, Aitken R, Tran L, Stone V, Duffin R, Forrest G, Alexander A. Carbon nanotubes: a review of their properties in relation to pulmonary toxicology and workplace safety. Toxicol. Sci 2006;92:522. [PubMed: 16484287]

Dosa PI, Erben C, Iyer VS, Vollhardt KPC, Wasser IM. Metal encapsulating carbon nanostructures from oligoalkyne metal complexes. J. Am. Chem. Soc 1999;121:10430-10431.

Dreher KL. Health and environmental impact of nanotechnology: toxicological assessment of manufactured nanoparticles. Toxicol. Sci 2004;77:3-5. [PubMed: 14756123]

Dufrene YF. Atomic force microscopy and chemical force microscopy of microbial cells. Nat. Protoc 2008;3:1132-1138. [PubMed: 18600218]

Dumortier H, Lacotte S, Pastorin G, Marega R, Wu W, Bonifazi D, Briand JP, Prato M, Muller S, Bianco A. Functionalized carbon nanotubes are noncytotoxic and preserve the functionality of primary immune cells. Nano Lett 2006;6:1522-1528. [PubMed: 16834443]

Dunning MD, Kettunen MI, Constant CF, Franklin RJM, Brindle KM. Magnetic resonance imaging of functional Schwann cell transplants labelled with magnetic microspheres. Neuroimage 2006;31:172-180. [PubMed: 16442816]

Dunning MD, Lakatos A, Loizou L, Kettunen M, ffrench-Constant C, Brindle KM, Franklin RJM. Superparamagnetic iron oxide-labeled Schwann cells and olfactory ensheathing cells can be traced in vivo by magnetic resonance imaging and retain functional properties after transplantation into the CNS. J. Neurosci 2004;24:9799-9810. [PubMed: 15525765]

Dutta D, Sundaram SK, Teeguarden JG, Riley BJ, Fifield LS, Jacobs JM, Addleman SR, Kaysen GA, Moudgil BM, Weber TJ. Adsorbed proteins influence the biological activity and molecular targeting of nanomaterials. Toxicol. Sci 2007;100:303-315. [PubMed: 17709331]

Eddaoudi M, Moler DB, Li HL, Chen BL, Reineke TM, O'Keeffe M, Yaghi OM. Modular chemistry: secondary building units as a basis for the design of highly porous and robust metal-organic carboxylate frameworks. Acc. Chem. Res 2001;34:319-330. [PubMed: 11308306]

Edwards PP, Thomas JM. Gold in a metallic divided state—from Faraday to present-day nanoscience. Angew. Chem. Int. Ed 2007;46:5480-5486.

El Hamaoui B, Zhi LJ, Wu JS, Kolb U, Mullen K. Uniform carbon and carbon/cobalt nanostructures by solid-state thermolysis of polyphenylene dendrimer/cobalt complexes. Adv. Mater 2005; 17:29572960.

Ellis-Behnke RG, Liang YX, You SW, Tay DKC, Zhang SG, So KF, Schneider GE. Nano neuro knitting: peptide nanofiber scaffold for brain repair and axon regeneration with functional return of vision. Proc. Natl. Acad. Sci. U.S.A 2006;103:5054-5059. [PubMed: 16549776]

Faber C, Zahneisen B, Tippmann F, Schroeder A, Fahrenholz F. Gradient-Echo and CRAZED imaging for minute detection of Alzheimer plaques in an APPV717I x ADAM10- $d n$ mouse model. Mag. Reson. Med 2007;57:696-703. 
Fall M, Guerbet M, Park B, Gouriou F, Dionnet F, Morin J-P. Evaluation of cerium oxide and cerium oxide based fuel additive safety on organotypic cultures of lung slices. Nanotoxicology 2007;1:227234.

Fan Y, Chen XT, Trigg AD, Tung CH, Kong JM, Gao ZQ. Detection of microRNAs using target-guided formation of conducting polymer nanowires in nanogaps. J. Am. Chem. Soc 2007;129:5437-5443. [PubMed: 17411036]

Fang SP, Lee HJ, Wark AW, Corn RM. Attomole microarray detection of microRNAs by nanoparticleamplified SPR imaging measurements of surface polyadenylation reactions. J. Am. Chem. Soc 2006;128:14044-14046. [PubMed: 17061884]

Faraday M. The Bakerian lecture: experimental relations of gold (and other metals) to light. Philos. Trans. R. Soc. Lond. Ser 1847;147:145-181.

Fiorito S, Serafino A, Andreola F, Togna A, Togna G. Toxicity and biocompatibility of carbon nanoparticies. J. Nanosci. Nanotech 2006;6:591-599.

Fischer TH, Thatte HS, Nichols TC, Bender-Neal DE, Bellinger DA, Vournakis JN. Synergistic platelet integrin signaling and factor XII activation in poly-N-acetyl glucosamine fiber-mediated hemostasis. Biomaterials 2005;26:5433-5443. [PubMed: 15860200]

Flaim CJ, Chien S, Bhatia SN. An extracellular matrix microarray for probing cellular differentiation. Nat. Methods 2005;2:119-125. [PubMed: 15782209]

Fowler DM, Koulov AV, Balch WE, Kelly JW. Functional amyloid-from bacteria to humans. Trends Biochem. Sci 2007;32:217-224. [PubMed: 17412596]

Freund HJ, Kuhlenbeck H, Staemmler V. Oxide surfaces. Rep. Prog. Phys 1996;59:283-347.

Friedbacher G, Hansma PK, Ramli E, Stucky GD. Imaging powders with the atomic force microscope —from biominerals to commercial materials. Science 1991;253:1261-1263. [PubMed: 17831444]

$\mathrm{Fu} \mathrm{AH}, \mathrm{Gu}$ WW, Larabell C, Alivisatos AP. Semiconductor nanocrystals for biological imaging. Curr. Opin. Neurobiol 2005;15:568-575. [PubMed: 16150591]

Fu CC, Lee HY, Chen K, Lim TS, Wu HY, Lin PK, Wei PK, Tsao PH, Chang HC, Fann W. Characterization and application of single fluorescent nanodiamonds as cellular biomarkers. Proc. Natl. Acad. Sci. U.S.A 2007;104:727-732. [PubMed: 17213326]

Fuller JE, Zugates GT, Ferreira LS, Ow HS, Nguyen NN, Wiesner UB, Langer RS. Intracellular delivery of core-shell fluorescent silica nanoparticles. Biomaterials 2008;29:1526-1532. [PubMed: 18096220]

Gao P, Xu H, Ding PT, Gao QZ, Sun JY, Chen DW. Controlled release of huperzine A from biodegradable microspheres: in vitro and in vivo studies. Int. J. Pharm 2007;330:1-5. [PubMed: 16987624]

Gao ZQ, Yang ZC. Detection of microRNAs using electrocatalytic nanoparticle tags. Anal. Chem 2006;78:1470-1477. [PubMed: 16503596]

Garibaldi S, Brunelli C, Bavastrello V, Ghigliotti G, Nicolini C. Carbon nanotube biocompatibility with cardiac muscle cells. Nanotechnology 2006;17:391-397.

Garnett MC, Kallinteri P. Nanomedicines and nanotoxicology: some physiological principles. Occup. Med. (Oxford) 2006;56:307-311.

Gemeinhart RA, Luo D, Saltzman WM. Cellular fate of a modular DNA delivery system mediated by silica nanoparticles. Biotechnol. Prog 2005;21:532-537. [PubMed: 15801794]

Geng Y, Dalhaimer P, Cai S, Tsai R, Tewari M, Minko T, Discher DE. Shape effects of filaments versus spherical particles in flow and drug delivery. Nat. Nanotechnol 2007;2:249-255. [PubMed: 18654271]

Gericke M, Pinches A. Biological synthesis of metal nanoparticles. Hydrometallurgy 2006;83:132-140.

Giovagnoli S, Luca G, Casaburi I, Blasi P, Macchiarulo G, Ricci M, Calvitti M, Basta G, Calafiore R, Rossi C. Long-term delivery of superoxide dismutase and catalase entrapped in poly(lactide-coglycolide) microspheres: in vitro effects on isolated neonatal porcine pancreatic cell clusters. J. Control. Release 2005;107:65-77. [PubMed: 15993507]

Gojova A, Guo B, Kota RS, Rutledge JC, Kennedy IM, Barakat AI. Induction of inflammation in vascular endothelial cells by metal oxide nanoparticles: effect of particle composition. Environ. Health Perspect 2007;115:403-409. [PubMed: 17431490] 
Graham L, Orenstein JM. Processing tissue and cells for transmission electron microscopy in diagnostic pathology and research. Nat. Protoc 2007;2:2439-2450. [PubMed: 17947985]

Gref R, Minamitake Y, Peracchia MT, Trubetskoy V, Torchilin V, Langer R. Biodegradable longcirculating polymeric nanospheres. Science 1994;263:1600-1603. [PubMed: 8128245]

Guo PX. RNA nanotechnology: engineering, assembly and applications in detection, gene delivery and therapy. J. Nanosci. Nanotech 2005;5:1964-1982.

Gupta AK, Gupta M. Synthesis and surface engineering of iron oxide nanoparticles for biomedical applications. Biomaterials 2005;26:3995-4021. [PubMed: 15626447]

Gurr J-R, Wang ASS, Chen C-H, Jan K-Y. Ultrafine titanium dioxide particles in the absence of photoactivation can induce oxidative damage to human bronchial epithelial cells. Toxicology 2005;213:66-73. [PubMed: 15970370]

Guzman J, Carrettin S, Corma A. Spectroscopic evidence for the supply of reactive oxygen during CO oxidation catalyzed by gold supported on nanocrystalline $\mathrm{CeO}_{2}$. J. Am. Chem. Soc 2005;127:32863287. [PubMed: 15755139]

Guzman KAD, Taylor MR, Banfield JF. Environmental risks of nanotechnology: national nanotechnology initiative funding, 2000-2004. Environ. Sci. Tech 2006;40:1401-1407.

Haes AJ, Chang L, Klein WL, Van Duyne RP. Detection of a biomarker for Alzheimer's disease from synthetic and clinical samples using a nanoscale optical biosensor. J. Am. Chem. Soc 2005a; 127:2264-2271. [PubMed: 15713105]

Haes AJ, Hall WP, Chang L, Klein WL, Van Duyne RP. A localized surface plasmon resonance biosensor: first steps toward an assay for Alzheimer's disease. Nano Lett 2004;4:1029-1034.

Haes AJ, Haynes CL, McFarland AD, Schatz GC, Van Duyne RR, Zou SL. Plasmonic materials for surface-enhanced sensing and spectroscopy. MRS Bull 2005b;30:368-375.

Han Y, Lee SS, Ying JY. Spherical siliceous mesocellular foam particles for high-speed size exclusion chromatography. Chem. Mater 2007;19:2292-2298.

Han YJ, Stucky GD, Butler A. Mesoporous silicate sequestration and release of proteins. J. Am. Chem. Soc 1999;121:9897-9898.

Han YJ, Watson JT, Stucky GD, Butler A. Catalytic activity of mesoporous silicate-immobilized chloroperoxidase. J. Mol. Catal. B: Enzym 2002;17:1-8.

Handy RD, Shaw BJ. Toxic effects of nanoparticles and nanomaterials: implications for public health, risk assessment and the public perception of nanotechnology. Health Risk Soc 2007;9:125-144.

Hannon GJ. RNA interference. Nature 2002;418:244-251. [PubMed: 12110901]

Hansma HG. Surface biology of DNA by atomic force microscopy. Annu. Rev. Phys. Chem 2001;52:7192. [PubMed: 11326059]

Hansma HG, Kim KJ, Laney DE, Garcia RA, Argaman M, Allen MJ, Parsons SM. Properties of biomolecules measured from atomic force microscope images: a review. J. Struct. Biol 1997;119:99-108. [PubMed: 9245749]

Hansma HG, Revenko I, Kim K, Laney DE. Atomic force microscopy of long and short double-stranded, single-stranded and triple-stranded nucleic acids. Nucleic Acids Res 1996;24:713-720. [PubMed: 8604315]

Hansma HG, Vesenka J, Siegerist C, Kelderman G, Morrett H, Sinsheimer RL, Elings V, Bustamante C, Hansma PK. Reproducible imaging and dissection of plasmid DNA under liquid with the atomic force microscope. Science 1992;256:1180-1184. [PubMed: 1589799]

Hardman R. A toxicologic review of quantum dots: toxicity depends on physicochemical and environmental factors. Environ. Health Perspect 2006;114:165-172. [PubMed: 16451849]

Harris JM, Chess RB. Effect of pegylation on pharmaceuticals. Nat. Rev. Drug Discov 2003;2:214-221. [PubMed: 12612647]

Harrison BS, Atala A. Carbon nanotube applications for tissue engineering. Biomaterials 2007;28:344353. [PubMed: 16934866]

Hashimoto K, Irie H, Fujishima $\mathrm{A} \mathrm{TiO}_{2}$ photocatalysis: a historical overview and future prospects. Jpn. J. Appl. Phys. Part 1: Regul. Pap. Brief Commun. Rev. Pap 2005;44:8269-8285.

Hayashi T, Hirono S, Tomita M, Umemura S. Magnetic thin films of cobalt nanocrystals encapsulated in graphite-like carbon. Nature 1996;381:772-774. 
He SY, Guo ZR, Zhang Y, Zhang S, Gu JWN. Biosynthesis of gold nanoparticles using the bacteria Rhodopseudomonas capsulata. Mater. Lett 2007;61:3984-3987.

Hebert SS, De Strooper B. miRNAs in neurodegeneration. Science 2007;317:1179-1180. [PubMed: 17761871]

Heidel JD, Yu ZP, Liu JYC, Rele SM, Liang YC, Zeidan RK, Kornbrust DJ, Davis ME. Administration in non-human primates of escalating intravenous doses of targeted nanoparticles containing ribonucleotide reductase subunit M2 siRNA. Proc. Natl. Acad. Sci. U.S.A 2007;104:5715-5721. [PubMed: 17379663]

Heller DA, Baik S, Eurell TE, Strano MS. Single-walled carbon nanotube spectroscopy in live cells: towards long-term labels and optical sensors. Adv. Mater 2005;17:2793-2799.

Heller DA, Jeng ES, Yeung TK, Martinez BM, Moll AE, Gastala JB, Strano MS. Optical detection of DNA conformational polymorphism on single-walled carbon nanotubes. Science 2006;311:508511. [PubMed: 16439657]

Hench LL, West JK. The sol—gel process. Chem. Rev 1990;90:33-72.

Heo C, Chang KA, Choi HS, Kim HS, Kim S, Liew H, Kim JA, Yu E, Ma J, Suh YH. Effects of the monomeric, oligomeric, and fibrillar $\mathrm{A} \beta_{42}$ peptides on the proliferation and differentiation of adult neural stem cells from subventricular zone. J. Neurochem 2007;102:493-500. [PubMed: 17403034]

Hext PM, Tomenson JA, Thompson P. Titanium dioxide: inhalation toxicology and epidemiology. Ann. Occup. Hyg 2005;49:461-472. [PubMed: 15790613]

Hill HD, Vega RA, Mirkin CA. Nonenzymatic detection of bacterial genomic DNA using the bio bar code assay. Anal. Chem 2007;79:9218-9223. [PubMed: 17927207]

Hirsch A. Addition-reactions of buckminsterfullerene $\left(C_{60}\right)$. Synthesis 1995:895-913.

Hodes G. When small is different: some recent advances in concepts and applications of nanoscale phenomena. Adv. Mater 2007;19:639-655.

Hofer R, Textor M, Spencer ND. Alkyl phosphate monolayers, self-assembled from aqueous solution onto metal oxide surfaces. Langmuir 2001;17:4014-4020.

Howard KA, Rahbek UL, Liu XD, Damgaard CK, Glud SZ, Andersen MO, Hovgaard MB, Schmitz A, Nyengaard JR, Besenbacher F, Kjems J. RNA interference in vitro and in vivo using a chitosan/ siRNA nanoparticle system. Mol. Ther 2006;14:476-484. [PubMed: 16829204]

Hu JT, Odom TW, Lieber CM. Chemistry and physics in one dimension: synthesis and properties of nanowires and nanotubes. Acc. Chem. Res 1999;32:435-445.

Huber DL. Synthesis, properties, and applications of iron nanoparticles. Small 2005;1:482-501. [PubMed: 17193474]

Huh YM, Jun YW, Song HT, Kim S, Choi JS, Lee JH, Yoon S, Kim KS, Shin JS, Suh JS, Cheon J. In vivo magnetic resonance detection of cancer by using multifunctional magnetic nanocrystals. J. Am. Chem. Soc 2005;127:12387-12391. [PubMed: 16131220]

Hui EE, Bhatia SN. Micromechanical control of cell—cell interactions. Proc. Natl. Acad. Sci. U.S.A 2007;104:5722-5726. [PubMed: 17389399]

Humphrey W, Dalke A, Schulten K. VMD: visual molecular dynamics. J. Mol. Graph 1996;14:33-38. [PubMed: 8744570]

Huo QS, Margolese DI, Ciesla U, Feng PY, Gier TE, Sieger P, Leon R, Petroff PM, Schuth F, Stucky GD. Generalized synthesis of periodic surfactant inorganic composite-materials. Nature 1994;368:317-321.

Hussain SM, Hess KL, Gearhart JM, Geiss KT, Schlager JJ. In vitro toxicity of nanoparticles in BRL 3A rat liver cells. Toxicol. In Vitro 2005;19:975-983. [PubMed: 16125895]

Hyeon T. Chemical synthesis of magnetic nanoparticles. Chem. Commun 2003:927-934.

International Council on Nanotechnology. [(accessed April 2007)]. http://icon.rice.edu

Intercampus Effort to Study Nanotoxicology. [(accessed July 2007)]. http://www.bren.ucsb.edu/news/press/nanotoxicology.htm

Institute of Bioengineering and Nanotechnology (IBN). [(accessed April 2007)]. http://www.ibn.a-star.edu.sg/ 
Ibrahim MA, Ismail A, Fetouh MI, Gopferich A. Stability of insulin during the erosion of poly(lactic acid) and poly(lactic-co-glycolic acid) microspheres. J. Control. Release 2005;106:241-252. [PubMed: 15970349]

Ideker T, Galitski T, Hood L. A new approach to decoding life: systems biology. Annu. Rev. Genomics Hum. Genet 2001;2:343-372. [PubMed: 11701654]

Iijima S. Helical microtubules of graphitic carbon. Nature 1991;354:56-58.

Iijima S, Yudasaka M, Yamada R, Bandow S, Suenaga K, Kokai F, Takahashi K. Nano-aggregates of single-walled graphitic carbon nano-horns. Chem. Phys. Lett 1999;309:165-170.

Ishiyama M, Tominaga H, Shiga M, Sasamoto K, Ohkura Y, Ueno K. A combined assay of cell viability and in vitro cytotoxicity with a highly watersoluble tetrazolium salt, neutral red and crystal violet. Biol. Pharmac. Bull 1996;19:1518-1520.

Isobe H, Tanaka T, Maeda R, Noiri E, Solin N, Yudasaka M, Iijima S, Nakamura E. Preparation, purification, characterization, and cytotoxicity assessment of water-soluble, transition-metal-free carbon nanotube aggregates. Angew. Chem. Int. Ed 2006;45:6676-6680.

Itaka K, Kanayama N, Nishiyama N, Jang WD, Yamasaki Y, Nakamura K, Kawaguchi H, Kataoka K. Supramolecular nanocarrier of siRNA from PEG-based block catiomer carrying diamine side chain with distinctive $\mathrm{pK}$ (a) directed to enhance intracellular gene silencing. J. Am. Chem. Soc 2004;126:13612-13613. [PubMed: 15493907]

Ito Y, Fukusaki E. DNA as a 'nanomaterial'. J. Mol. Catal. B: Enzym 2004;28:155-166.

Iyer VS, Vollhardt KPC, Wilhelm R. Near-quantitative solid-state synthesis of carbon nanotubes from homogeneous diphenylethynecobalt and -nickel complexes. Angew. Chem. Int. Ed 2003;42:43794383.

Jan E, Kotov NA. Successful differentiation of mouse neural stem cells on layer-by-layer assembled single-walled carbon nanotube composite. Nano Lett 2007;7:1123-1128. [PubMed: 17451277]

Jeng ES, Moll AE, Roy AC, Gastala JB, Strano MS. Detection of DNA hybridization using the nearinfrared band-gap fluorescence of single-walled carbon nanotubes. Nano Lett 2006;6:371-375. [PubMed: 16522025]

Jensen AW, Wilson SR, Schuster DI. Biological applications of fullerenes. Bioorg. Med. Chem 1996;4:767-779. [PubMed: 8818226]

Jeong U, Teng XW, Wang Y, Yang H, Xia YN. Superparamagnetic colloids: controlled synthesis and niche applications. Adv. Mater 2007;19:33-60.

Jia G, Wang HF, Yan L, Wang X, Pei RJ, Yan T, Zhao YL, Guo XB. Cytotoxicity of carbon nanomaterials: single-wall nanotube, multi-wall nanotube, and fullerene. Environ. Sci. Tech 2005;39:1378-1383.

Jiao J, Seraphin S, Wang XK, Withers JC. Preparation and properties of ferromagnetic carbon-coated Fe, Co, and Ni nanoparticles. J. Appl. Phys 1996;80:103-108.

Jo K, Heien ML, Thompson LB, Zhong M, Nuzzo RG, Sweedler JV. Mass spectrometric imaging of peptide release from neuronal cells within microfluidic devices. Lab Chip 2007;7:1454-1460. [PubMed: 17960271]

Josephson L, Kircher MF, Mahmood U, Tang Y, Weissleder R. Nearinfrared fluorescent nanoparticles as combined MR/optical imaging probes. Bioconj. Chem 2002;13:554-560.

Jovanovic AV, Flint JA, Varshney M, Morey TE, Dennis DM, Duran RS. Surface modification of silica core—shell nanocapsules: biomedical implications. Biomacromolecules 2006;7:945-949. [PubMed: 16529435]

Jun YW, Huh YM, Choi JS, Lee JH, Song HT, Kim S, Yoon S, Kim KS, Shin JS, Suh JS, Cheon J. Nanoscale size effect of magnetic nanocrystals and their utilization for cancer diagnosis via magnetic resonance imaging. J. Am. Chem. Soc 2005;127:5732-5733. [PubMed: 15839639]

Jun YW, Jang JT, Cheon J. Nanocrystals and their biomedical applications. Bull. Korean Chem. Soc 2006;27:961-971.

Jurchen JC, Rubakhin SS, Sweedler JV. MALDI-MS imaging of features smaller than the size of the laser beam. J. Am. Soc. Mass Spectrom 2005;16:1654-1659. [PubMed: 16095912]

Kada G, Kienberger F, Hinterdorfer P. Atomic force microscopy in bionanotechnology. Nano Today 2008;3:12-19. 
Kale SN, Arora S, Bhayani KR, Paknikar KM, Jani M, Wagh UV, Kulkarni SD, Ogale SB. Cerium doping and stoichiometry control for biomedical use of $\mathrm{La}_{0.7} \mathrm{Sr}_{0.3} \mathrm{MnO}_{3}$ nanoparticles: microwave absorption and cytotoxicity study. Nanomed. Nanotechnol. Biol. Med 2006;2:217-221.

Kam NWS, Jessop TC, Wender PA, Dai HJ. Nanotube molecular transporters: internalization of carbon nanotube-protein conjugates into mammalian cells. J. Am. Chem. Soc 2004;126:6850-6851. [PubMed: 15174838]

Kane RS, Takayama S, Ostuni E, Ingber DE, Whitesides GM. Patterning proteins and cells using soft lithography. Biomaterials 1999;20:2363-2376. [PubMed: 10614942]

Karakoti AS, Hench LL, Seal S. The potential toxicity of nanomaterials-the role of surfaces. J. Min. Met. Mater. Soc 2006;58:77-82.

Karlsson N, Cassel G, Fangmark I, Bergman F. A comparative-study of the acute inhalation toxicity of smoke from $\mathrm{TiO}_{2}$-hexachloroethane and $\mathrm{Zn}$-hexachloroethane pyrotechnic mixtures. Arch. Toxicol 1986;59:160-166. [PubMed: 3813883]

Ke PC, Qiao R. Carbon nanomaterials in biological systems. J. Phys.: Condes. Matter 2007:19.

Khetani SR, Bhatia SN. Microscale culture of human liver cells for drug development. Nat. Biotechnol 2008;26:120-126. [PubMed: 18026090]

Kim J, Grate JW, Wang P. Nanostructures for enzyme stabilization. Chem. Eng. Sci 2006a;61:10171026.

Kim J, Lee JE, Lee J, Yu JH, Kim BC, An K, Hwang Y, Shin CH, Park JG, Kim J, Hyeon T. Magnetic fluorescent delivery vehicle using uniform mesoporous silica spheres embedded with monodisperse magnetic and semiconductor nanocrystals. J. Am. Chem. Soc 2006b;128:688-689. [PubMed: 16417336]

Kim JK, Lee WK, Lee EJ, Cho YJ, Lee KH, Kim HS, Chung Y, Kim KA, Lim Y. Mechanism of silicaand titanium dioxide-induced cytotoxicity in alveolar macrophages. J. Toxicol. Environ. Health A 1999;58:437-450. [PubMed: 10616192]

Kim JS, Rieter WJ, Taylor KML, An H, Lin W, Lin W. Self-assembled hybrid nanoparticles for cancerspecific multimodal imaging. J. Am. Chem. Soc 2007a;129:8962-8963. [PubMed: 17602632]

Kim MI, Kim J, Lee J, Jia H, Bin Na H, Youn JK, Kwak JH, Dohnalkova A, Grate JW, Wang P, Hyeon T, Park HG, Chang HN. Crosslinked enzyme aggregates in hierarchically-ordered mesoporous silica: a simple and effective method for enzyme stabilization. Biotechnol. Bioeng 2007b;96:210218. [PubMed: 16986168]

Kim SW, Son SU, Lee SI, Hyeon T, Chung YK. Cobalt on mesoporous silica: the first heterogeneous Pauson-Khand catalyst. J. Am. Chem. Soc 2000;122:1550-1551.

Kim W, Ng JK, Kunitake ME, Conklin BR, Yang PD. Interfacing silicon nanowires with mammalian cells. J. Am. Chem. Soc 2007c;129:7228-7229. [PubMed: 17516647]

Kimura Y, Shibasaki S, Morisato K, Ishizuka N, Minakuchi H, Nakanishi K, Matsuo M, Amachi T, Ueda M, Ueda K. Microanalysis for MDR1 ATPase by high-performance liquid chromatography with a titanium dioxide column. Anal. Biochem 2004;326:262-266. [PubMed: 15003566]

Kirchner C, Liedl T, Kudera S, Pellegrino T, Javier AM, Gaub HE, Stolzle S, Fertig N, Parak WJ. Cytotoxicity of colloidal CdSe and CdSe/ZnS nanoparticles. Nano Lett 2005;5:331-338. [PubMed: 15794621]

Kiseleva E, Allen TD, Rutherford SA, Murray S, Morozova K, Gardiner F, Goldberg MW, Drummond SP. A protocol for isolation and visualization of yeast nuclei by scanning electron microscopy (SEM). Nat. Protoc 2007;2:1943-1953. [PubMed: 17703206]

Kitano H. Computational systems biology. Nature 2002a;420:206-210. [PubMed: 12432404]

Kitano H. Systems biology: a brief overview. Science 2002b;295:1662-1664. [PubMed: 11872829]

Klein J. Probing the interactions of proteins and nanoparticles. Proc. Natl. Acad. Sci. U.S.A 2007;104:2029-2030. [PubMed: 17284585]

Klejbor I, Stachowiak EK, Bharali DJ, Roy I, Spodnik I, Morys J, Bergey EJ, Prasad PN, Stachowiak MK. ORMOSIL nanoparticles as a non-viral gene delivery vector for modeling polyglutamine induced brain pathology. J. Neurosci. Methods 2007;165:230-243. [PubMed: 17655935]

Kneuer C, Sameti M, Bakowsky U, Schiestel T, Schirra H, Schmidt H, Lehr CM. A nonviral DNA delivery system based on surface modified silica-nanoparticles can efficiently transfect cells in vitro. Bioconj. Chem 2000a;11:926-932. 
Kneuer C, Sameti M, Haltner EG, Schiestel T, Schirra H, Schmidt H, Lehr CM. Silica nanoparticles modified with aminosilanes as carriers for plasmid DNA. Int. J. Pharm 2000b;196:257-261. [PubMed: 10699731]

Kogan MJ, Bastus NG, Amigo R, Grillo-Bosch D, Araya E, Turiel A, Labarta A, Giralt E, Puntes VF. Nanoparticle-mediated local and remote manipulation of protein aggregation. Nano Lett 2006;6:110-115. [PubMed: 16402797]

Kong GKW, Adams JJ, Harris HH, Boas JF, Curtain CC, Galatis D, Masters CL, Barnham KJ, McKinstry WJ, Cappai R, Parker MW. Structural studies of the Alzheimer's amyloid precursor protein copperbinding domain reveal how it binds copper ions. J. Mol. Biol 2007;367:148-161. [PubMed: 17239395]

Konishi Y, Ohno K, Saitoh N, Nomura T, Nagamine S, Hishida H, Takahashi Y, Uruga T. Bioreductive deposition of platinum nanoparticles on the bacterium Shewanella algae. J. Biotechnol 2007;128:648-653. [PubMed: 17182148]

Konishi Y, Tsukiyama T, Ohno K, Saitoh N, Nomura T, Nagamine S. Intracellular recovery of gold by microbial reduction of $\mathrm{AuCl}_{4}{ }^{-}$ions using the anaerobic bacterium Shewanella algae. Hydrometallurgy 2006;81:24-29.

Kosik KS. The neuronal microRNA system. Nat. Rev. Neurosci 2006;7:911-920. [PubMed: 17115073]

Kosik KS, Krichevsky AM. The elegance of the microRNAs: a neuronal perspective. Neuron 2005;47:779-782. [PubMed: 16157272]

Kostarelos K, Lacerda L, Pastorin G, Wu W, Wieckowski S, Luangsivilay J, Godefroy S, Pantarotto D, Briand JP, Muller S, Prato M, Bianco A. Cellular uptake of functionalized carbon nanotubes is independent of functional group and cell type. Nat. Nanotechnol 2007;2:108-113. [PubMed: 18654229]

Kostiainen MA, Szilvay GR, Lehtinen J, Smith DK, Linder MB, Urtti A, Ikkala O. Precisely defined protein-polymer conjugates: construction of synthetic DNA binding domains on proteins by using multivalent dendrons. ACS Nano 2007;1:103-113. [PubMed: 19206526]

Kovacs EW, Hooker JM, Romanini DW, Holder PG, Berry KE, Francis MB. Dual-surface-modified bacteriophage MS2 as an ideal scaffold for a viral capsid-based drug delivery system. Bioconj. Chem 2007;18:1140-1147.

Kraemer SM. Iron oxide dissolution and solubility in the presence of siderophores. Aquat. Sci 2004;66:318.

Kroto HW, Heath JR, O’Brien SC, Curl RF, Smalley RE. C60: Buckminsterfullerene. Nature 1985;318:162-163.

Kruse R, Sweedler JV. Spatial profiling invertebrate ganglia using MALDI MS. J. Am. Soc. Mass Spectrom 2003;14:752-759. [PubMed: 12837597]

Kubo T, Zhelev Z, Ohba H, Bakalova R. Chemically modified symmetric and asymmetric duplex RNAs: an enhanced stability to nuclease degradation and gene silencing effect. Biochem. Biophys. Res. Commun 2008;365:54-61. [PubMed: 17971296]

Labhasetwar V. Nanotechnology for drug and gene therapy: the importance of understanding molecular mechanisms of delivery. Curr. Opin. Biotechnol 2005;16:674-680. [PubMed: 16263259]

Laibinis PE, Whitesides GM, Allara DL, Tao YT, Parikh AN, Nuzzo RG. Comparison of the structures and wetting properties of self-assembled monolayers of normal-alkanethiols on the coinage metalsurfaces, Cu, Ag, Au. J. Am. Chem. Soc 1991;113:7152-7167.

Lal R, Drake B, Blumberg D, Saner DR, Hansma PK, Feinstein SC. Imaging real-time neurite outgrowth and cytoskeletal reorganization with an atomic-force microscope. Am. J. Physiol. Cell. Physiol 1995;38:C275-C285.

Lam CW, James JT, McCluskey R, Arepalli S, Hunter RL. A review of carbon nanotube toxicity and assessment of potential occupational and environmental health risks. Crit. Rev. Toxicol 2006;36:189-217. [PubMed: 16686422]

Lam CW, James JT, McCluskey R, Hunter RL. Pulmonary toxicity of single-wall carbon nanotubes in mice 7 and 90 days after intratracheal instillation. Toxicol. Sci 2004;77:126-134. [PubMed: 14514958]

Langer R. New methods of drug delivery. Science 1990;249:1527-1533. [PubMed: 2218494] 
Lashuel HA, Lansbury PT. Are amyloid diseases caused by protein aggregates that mimic bacterial poreforming toxins? Q. Rev. Biophys 2006;39:167-201. [PubMed: 16978447]

Lavalley JC. Infrared spectrometric studies of the surface basicity of metal oxides and zeolites using adsorbed probe molecules. Catal. Today 1996;27:377-401.

Lee IS, Lee N, Park J, Kim BH, Yi YW, Kim T, Kim TK, Lee IH, Paik SR, Hyeon T. Ni/NiO core/shell nanoparticles for selective binding and magnetic separation of histidine-tagged proteins. J. Am. Chem. Soc 2006a;128:10658-10659. [PubMed: 16910642]

Lee J, Kim J, Hyeon T. Recent progress in the synthesis of porous carbon materials. Adv. Mater 2006b; 18:2073-2094.

Lee JH, Jun YW, Yeon SI, Shin JS, Cheon J. Dual-mode nanoparticle probes for high-performance magnetic resonance and fluorescence imaging of neuroblastoma. Angew. Chem. Int. Ed 2006c; 45:8160-8162.

Lee KB, Kim EY, Mirkin CA, Wolinsky SM. The use of nanoarrays for highly sensitive and selective detection of human immunodeficiency virus type 1 in plasma. Nano Lett 2004a;4:1869-1872.

Lee KB, Park S, Mirkin CA. Multicomponent magnetic nanorods for biomolecular separations. Angew. Chem. Int. Ed 2004b;43:3048-3050.

Lee S-M, Cho S-N, Cheon J. Anisotropic shape control of colloidal inorganic nanocrystals. Adv. Mater 2003;15:441-444.

Lei ZB, Xiao Y, Dang LQ, Lu M, You WS. Fabrication of ultra-large mesoporous carbon with tunable pore size by monodisperse silica particles derived from seed growth process. Micropor. Mesopor. Mater 2006;96:127-134.

Levy L, Sahoo Y, Kim KS, Bergey EJ, Prasad PN. Nanochemistry: synthesis and characterization of multifunctional nanoclinics for biological applications. Chem. Mater 2002;14:3715-3721.

Li WJ, Szoka FC. Lipid-based nanoparticles for nucleic acid delivery. Pharmac. Res 2007;24:438-449.

Liang S, Wang YX, Yu JF, Zhang CF, Xia JY, Yin DZ. Surface modified superparamagnetic iron oxide nanoparticles: as a new carrier for bio-magnetically targeted therapy. J. Mater. Sci. Mater. Med 2007;18:2297-2302. [PubMed: 17562137]

Limbach LK, Li Y, Grass RN, Brunner TJ, Hintermann MA, Muller M, Gunther D, Stark WJ. Oxide nanoparticle uptake in human lung fibroblasts: effects of particle size, agglomeration, and diffusion at low concentrations. Environ. Sci. Technol 2005;39:9370-9376. [PubMed: 16382966]

Lin WS, Huang YW, Zhou XD, Ma YF. In vitro toxicity of silica nanoparticles in human lung cancer cells. Toxicol. Appl. Pharmacol 2006a;217:252-259. [PubMed: 17112558]

Lin WS, Huang YW, Zhou XD, Ma YF. Toxicity of cerium oxide nanoparticles in human lung cancer cells. Int. J. Toxicol 2006b;25:451-457. [PubMed: 17132603]

Lin YS, Wu SH, Hung Y, Chou YH, Chang C, Lin ML, Tsai CP, Mou CY. Multifunctional composite nanoparticles: magnetic, luminescent, and mesoporous. Chem. Mater 2006c;18:5170-5172.

Linnainmaa K, Kivipensas P, Vainio H. Toxicity and cytogenetic studies of ultrafine titanium dioxide in cultured rat liver epithelial cells. Toxicol. In Vitro 1997;11:329-335.

Liopo AV, Stewart MP, Hudson J, Tour JM, Pappas TC. Biocompatibility of native and functionalized single-walled carbon nanotubes for neuronal interface. J. Nanosci. Nanotech 2006;6:1365-1374.

Liu CH, Huang SN, Cui JK, Kim YR, Farrar CT, Moskowitz MA, Rosen BR, Liu PK. MR contrast probes that trace gene transcripts for cerebral ischemia in live animals. FASEB J 2007a;21:3004-3015. [PubMed: 17478745]

Liu CH, Kim YR, Ren JQ, Eichler F, Rosen BR, Liu PK. Imaging cerebral gene transcripts in live animals. J. Neurosci 2007b;27:713-722. [PubMed: 17234603]

Liu G, Garrett MR, Men P, Zhu XW, Perry G, Smith MA. Nanoparticle and other metal chelation therapeutics in Alzheimer disease. Biochim. Biophys. Acta: Mol. Basis Dis 2005a;1741:246-252.

Liu J, Lu Y. Stimuli-responsive disassembly of nanoparticle aggregates for light-up colorimetric sensing. J. Am. Chem. Soc 2005;127:12677-12683. [PubMed: 16144417]

Liu J, Lu Y. Preparation of aptamer-linked gold nanoparticle purple aggregates for colorimetric sensing of analytes. Nat. Protoc 2006a;1:246-252. [PubMed: 17406240]

Liu JW, Lu Y. A colorimetric lead biosensor using DNAzyme-directed assembly of gold nanoparticles. J. Am. Chem. Soc 2003;125:6642-6643. [PubMed: 12769568] 
Liu JW, Lu Y. Accelerated color change of gold nanoparticles assembled by DNAzymes for simple and fast colorimetric $\mathrm{Pb}^{2+}$ detection. J. Am. Chem. Soc 2004a;126:12298-12305. [PubMed: 15453763]

Liu JW, Lu Y. Adenosine-dependent assembly of aptazyme-functionalized gold nanoparticles and its application as a colorimetric biosensor. Anal. Chem 2004b;76:1627-1632. [PubMed: 15018560]

Liu JW, Lu Y. Fast colorimetric sensing of adenosine and cocaine based on a general sensor design involving aptamers and nanoparticles. Angew. Chem. Int. Ed 2006b;45:90-94.

Liu JW, Mazumdar D, Lu Y. A simple and sensitive "dipstick" test in serum based on lateral flow separation of aptamer-linked nanostructures. Angew. Chem. Int. Ed 2006;45:7955-7959.

Liu WT. Nanoparticles and their biological and environmental applications. J. Biosci. Bioeng 2006;102:1-7. [PubMed: 16952829]

Liu YF, Wang SP, Lee JW, Kotov NA. A floating self-assembly route to colloidal crystal templates for 3D cell scaffolds. Chem. Mater 2005b;17:4918-4924.

Livage J, Henry M, Sanchez C. Sol—gel chemistry of transition-metal oxides. Prog. Solid State Chem 1988;18:259-341.

Lockman PR, Mumper RJ, Khan MA, Allen DD. Nanoparticle technology for drug delivery across the blood-brain barrier. Drug Dev. Ind. Pharm 2002;28:1-13. [PubMed: 11858519]

Long TC, Saleh N, Tilton RD, Lowry GV, Veronesi B. Titanium dioxide (P25) produces reactive oxygen species in immortalized brain microglia (BV2): implications for nanoparticle neurotoxicity. Environ. Sci. Tech 2006;40:4346-4352.

Loo L, Guenther RH, Lommel SA, Franzen S. Encapsidation of nanoparticies by Red Clover Necrotic Mosaic Virus. J. Am. Chem. Soc 2007;129:11111-11117. [PubMed: 17705477]

Love JC, Estroff LA, Kriebel JK, Nuzzo RG, Whitesides GM. Self-assembled monolayers of thiolates on metals as a form of nanotechnology. Chem. Rev 2005;105:1103-1169. [PubMed: 15826011]

Lovric J, Bazzi HS, Cuie Y, Fortin GRA, Winnik FM, Maysinger D. Differences in subcellular distribution and toxicity of green and red emitting CdTe quantum dots. J. Mol. Med 2005a;83:377385. [PubMed: 15688234]

Lovric J, Cho SJ, Winnik FM, Maysinger D. Unmodified cadmium telluride quantum dots induce reactive oxygen species formation leading to multiple organelle damage and cell death. Chem. Biol 2005b; 12:1227-1234. [PubMed: 16298302]

Lu AH, Li WC, Salabas EL, Spliethoff B, Schuth F. Low temperature catalytic pyrolysis for the synthesis of high surface area, nanostructured graphitic carbon. Chem. Mater 2006;18:2086-2094.

Lu AH, Salabas EL, Schuth F. Magnetic nanoparticles: synthesis, protection, functionalization, and application. Angew. Chem. Int. Ed 2007a;46:1222-1244.

Lu AH, Schuth F. Nanocasting: a versatile strategy for creating nanostructured porous materials. Adv. Mater 2006;18:1793-1805.

Lu J, Liong M, Zink JI, Tamanoi F. Mesoporous silica nanoparticles as a delivery system for hydrophobic anticancer drugs. Small 2007b;3:1341-1346. [PubMed: 17566138]

Lu Y, Liu JW. Functional DNA nanotechnology: emerging applications of DNAzymes and aptamers. Curr. Opin. Biotechnol 2006;17:580-588. [PubMed: 17056247]

Lu Y, Liu JW. Smart nanomaterials inspired by biology: dynamic assembly of error-free nanomaterials in response to multiple chemical and biological stimuli. Acc. Chem. Res 2007;40:315-323. [PubMed: 17474707]

Luckarift HR, Spain JC, Naik RR, Stone MO. Enzyme immobilization in a biomimetic silica support. Nat. Biotechnol 2004;22:211-213. [PubMed: 14716316]

Lyubchenko YL, Sherman S, Shlyakhtenko LS, Uversky VN. Nanoimaging for protein misfolding and related diseases. J. Cell. Biochem 2006;99:53-70.

Mann DGJ, McKnight TE, McPherson JT, Hoyt PR, Melechko AV, Simpson ML, Sayler GS. Inducible RNA interference-mediated gene silencing using nanostructured gene delivery arrays. ACS Nano 2008;2:69-76. [PubMed: 19206549]

Manna SK, Sarkar S, Barr J, Wise K, Barrera EV, Jejelowo O, Rice-Ficht AC, Ramesh GT. Single-walled carbon nanotube induces oxidative stress and activates nuclear transcription factor-kappa B in human keratinocytes. Nano Lett 2005;5:1676-1684. [PubMed: 16159204]

Marris E. Four years in Iraq— the war against wounds. Nature 2007;446:369-371. [PubMed: 17377559] 
Marshall MJ, Beliaev AS, Dohnalkova AC, Kennedy DW, Shi L, Wang ZM, Boyanov MI, Lai B, Kemner KM, McLean JS, Reed SB, Culley DE, Bailey VL, Simonson CJ, Saffarini DA, Romine MF, Zachara JM, Fredrickson JK. c-Type cytochrome-dependent formation of U(IV) nanoparticles by Shewanella oneidensis. PLoS. Biol 2006;4:1324-1333.

Martin CR, Kohli P. The emerging field of nanotube biotechnology. Nat. Rev. Drug Discov 2003;2:29_ 37. [PubMed: 12509757]

Masotti A, Vicennati P, Boschi F, Calderan L, Sbarbati A, Ortaggi G. A novel near-infrared indocyanine dye-polyethylenimine conjugate allows DNA delivery imaging in vivo. Bioconj. Chem 2008;19:983-987.

Matsumura S, Ajima K, Yudasaka M, Iijima S, Shiba K. Dispersion of cisplatin-loaded carbon nanohorns with a conjugate comprised of an artificial peptide aptamer and polyethylene glycol. Mol. Pharmaceutics 2007;4:723-729.

Maynard AD, Aitken RJ, Butz T, Colvin V, Donaldson K, Oberdoerster G, Philbert MA, Ryan J, Seaton A, Stone V, Tinkle SS, Tran L, Walker NJ, Warheit DB. Safe handling of nanotechnology. Nature 2006;444:267-269. [PubMed: 17108940]

Maynard AD, Baron PA, Foley M, Shvedova AA, Kisin ER, Castranova V. Exposure to carbon nanotube material: aerosol release during the handling of unrefined single-walled carbon nanotube material. J. Toxicol. Environ. Health. A 2004;67:87-107. [PubMed: 14668113]

Maynard AD, Kuempel ED. Airborne nanostructured particles and occupational health. J. Nanopart. Res 2005;7:587-614.

McKnight TE, Melechko AV, Griffin GD, Guillorn MA, Merkulov VI, Serna F, Hensley DK, Doktycz MJ, Lowndes DH, Simpson ML. Intracellular integration of synthetic nanostructures with viable cells for controlled biochemical manipulation. Nanotechnology 2003;14:551-556.

McKnight TE, Melechko AV, Hensley DK, Mann DGJ, Griffin GD, Simpson ML. Tracking gene expression after DNA delivery using spatially indexed nanofiber arrays. Nano Lett 2004;4:12131219.

Medina C, Santos-Martinez MJ, Radomski A, Corrigan OI, Radomski MW. Nanoparticles: pharmacological and toxicological significance. Br. J. Pharmacol 2007;150:552-558. [PubMed: 17245366]

Medintz IL, Uyeda HT, Goldman ER, Mattoussi H. Quantum dot bioconjugates for imaging, labelling and sensing. Nat. Mater 2005;4:435-446. [PubMed: 15928695]

Michalet X, Pinaud FF, Bentolila LA, Tsay JM, Doose S, Li JJ, Sundaresan G, Wu AM, Gambhir SS, Weiss S. Quantum dots for live cells, in vivo imaging, and diagnostics. Science 2005;307:538-544. [PubMed: 15681376]

Millet LJ, Stewart ME, Sweedler JV, Nuzzo RG, Gillette MU. Microfluidic devices for culturing primary mammalian neurons at low densities. Lab Chip 2007;7:987-994. [PubMed: 17653340]

Mirkin CA. Programming the assembly of two- and three-dimensional architectures with DNA and nanoscale inorganic building blocks. Inorg. Chem 2000;39:2258-2272. [PubMed: 12526483]

Mishra S, Webster P, Davis ME. PEGylation significantly affects cellular uptake and intracellular trafficking of non-viral gene delivery particles. Eur. J. Cell Biol 2004;83:97-111. [PubMed: 15202568]

Miyawaki J, Yudasaka M, Imai H, Yorimitsu H, Isobe H, Nakamura E, Iijima S. In vivo magnetic resonance imaging of single-walled carbon nanohorns by labeling with magnetite nanoparticles. Adv. Mater 2006;18:1010-1014.

Mogensen M, Sammes NM, Tompsett GA. Physical, chemical and electrochemical properties of pure and doped ceria. Solid State Ion 2000;129:63-94.

Moller W, Hofer T, Ziesenis A, Karg E, Heyder J. Ultrafine particles cause cytoskeletal dysfunctions in macrophages. Toxicol. Appl. Pharmacol 2002;182:197-207. [PubMed: 12183099]

Monica JC, Heintz ME, Lewis PT. The perils of pre-emptive regulation. Nat. Nanotechnol 2007;2:6870. [PubMed: 18654214]

Monnier A, Schuth F, Huo Q, Kumar D, Margolese D, Maxwell RS, Stucky GD, Krishnamurty M, Petroff P, Firouzi A, Janicke M, Chmelka BF. Cooperative Formation of inorganic-organic interfaces in the synthesis of silicate mesostructures. Science 1993;261:1299-1303. [PubMed: 17731857] 
Monroe EB, Jurchen JC, Lee J, Rubakhin SS, Sweedler JV. Vitamin E imaging and localization in the neuronal membrane. J. Am. Chem. Soc 2005;127:12152-12153. [PubMed: 16131155]

Monteiro-Riviere NA, Nemanich RJ, Inman AO, Wang YYY, Riviere JE. Multi-walled carbon nanotube interactions with human epidermal keratinocytes. Toxicol. Lett 2005;155:377-384. [PubMed: 15649621]

Moore A, Marecos E, Bogdanov A, Weissleder R. Tumoral distribution of long-circulating dextrancoated iron oxide nanoparticles in a rodent model. Radiology 2000;214:568-574. [PubMed: 10671613]

Moreau JW, Weber PK, Martin MC, Gilbert B, Hutcheon ID, Banfield JF. Extracellular proteins limit the dispersal of biogenic nanoparticles. Science 2007;316:1600-1603. [PubMed: 17569859]

Mornet S, Vasseur S, Grasset F, Duguet E. Magnetic nanoparticle design for medical diagnosis and therapy. J. Mater. Chem 2004;14:2161-2175.

Mosmann T. Rapid colorimetric assay for cellular growth and survival—application to proliferation and cyto-toxicity assays. J. Immunol. Methods 1983;65:55-63. [PubMed: 6606682]

Mrksich M, Whitesides GM. Using self-assembled monolayers to understand the interactions of manmade surfaces with proteins and cells. Annu. Rev. Biophys. Biomol. Struct 1996;25:55-78. [PubMed: 8800464]

Muldoon LL, Sandor M, Pinkston KE, Neuwelt EA. Imaging, distribution, and toxicity of superparamagnetic iron oxide magnetic resonance nanoparticles in the rat brain and intracerebral tumor. Neurosurgery 2005;57:785-796. [PubMed: 16239893]

Murakami T, Ajima K, Miyawaki J, Yudasaka M, Iijima S, Shiba K. Drugloaded carbon nanohorns: adsorption and release of dexamethasone in vitro. Mol. Pharmaceutics 2004;1:399-405.

Murray CB, Sun SH, Doyle H, Betley T. Monodisperse 3d transition-metal (Co, Ni, Fe) nanoparticles and their assembly into nanoparticle superlattices. MRS Bull 2001;26:985-991.

Muscariello L, Rosso F, Marino G, Giordano A, Barbarisi M, Cafiero G, Barbarisi A. A critical overview of ESEM applications in the biological field. J. Cell. Physiol 2005;205:328-334. [PubMed: 15965928]

Narita M, Tanaka H, Togashi T, Abe S. Cytokines involved in CNS manifestations caused by Mycoplasma pneumoniae. Pediatr. Neurol 2005;33:105-109. [PubMed: 16087054]

Nel A, Xia T, Madler L, Li N. Toxic potential of materials at the nanolevel. Science 2006;311:622-627. [PubMed: 16456071]

Neuwelt EA, Varallyay CG, Manninger S, Solymosi D, Haluska M, Hunt MA, Nesbit G, Stevens A, Jerosch-Herold M, Jacobs PM, Hoffman JM. The potential of ferumoxytol nanoparticle magnetic resonance imaging, perfusion, and angiography in central nervous system malignancy: a pilot study. Neurosurgery 2007;60:601-611. [PubMed: 17415196]

Niu JL, Azfer A, Rogers LM, Wang XH, Kolattukudy PE. Cardioprotective effects of cerium oxide nanoparticles in a transgenic murine model of cardiomyopathy. Cardiovasc. Res 2007;73:549-559. [PubMed: 17207782]

Norris DJ, Vlasov YA. Chemical approaches to three-dimensional semiconductor photonic crystals. Adv. Mater 2001;13:371-376.

Northen TR, Yanes O, Northen MT, Marrinucci D, Uritboonthai W, Apon J, Golledge SL, Nordstrom A, Siuzdak G. Clathrate nanostructures for mass spectrometry. Nature 2007;449:1033-11033. [PubMed: 17960240]

Nanotechnology Characterization Laboratory (NCL). [(accessed April 2007)]. http://ncl.cancer.gov/

Oberdorster E. Manufactured nanomaterials (fullerenes, $\mathrm{C}_{60}$ ) induce oxidative stress in the brain of juvenile largemouth bass. Environ. Health. Perspect 2004;112:1058-1062. [PubMed: 15238277]

Oberdorster G, Oberdorster E, Oberdorster J. Nanotoxicology: an emerging discipline evolving from studies of ultrafine particles. Environ. Health Perspect 2005;113:823-839. [PubMed: 16002369]

Odom TW, Huang JL, Kim P, Lieber CM. Atomic structure and electronic properties of single-walled carbon nanotubes. Nature 1998;391:62-64.

Ogris M, Brunner S, Schuller S, Kircheis R, Wagner E. PEGylated DNA/transferrin-PEI complexes: reduced interaction with blood components, extended circulation in blood and potential for systemic gene delivery. Gene Ther 1999;6:595-605. [PubMed: 10476219] 
Ohulchanskyy TY, Roy I, Goswami LN, Chen Y, Bergey EJ, Pandey RK, Oseroff AR, Prasad PN. Organically modified silica nanoparticles with covalently incorporated photosensitizer for photodynamic therapy of cancer. Nano Lett 2007;7:2835-2842. [PubMed: 17718587]

Oishi M, Nagasaki Y, Itaka K, Nishiyama N, Kataoka K. Lactosylated poly(ethylene glycol)-siRNA conjugate through acid-labile $\beta$-thiopropionate linkage to construct $\mathrm{pH}$-sensitive polyion complex micelles achieving enhanced gene silencing in hepatoma cells. J. Am. Chem. Soc 2005;127:16241625. [PubMed: 15700981]

Oishi M, Nagasaki Y, Nishiyama N, Itaka K, Takagi M, Shimamoto A, Furuichi Y, Kataoka K. Enhanced growth inhibition of hepatic multicellular tumor spheroids by lactosylated poly(ethylene glycol)siRNA conjugate formulated in PEGylated polyplexes. ChemMedChem 2007;2:1290-1297. [PubMed: 17546711]

Ostomel TA, Shi Q, Stoimenov PK, Stucky GD. Metal-oxide surface-charge mediated hemostasis. Langmuir 2007;23:11233-11238. [PubMed: 17892311]

Ostomel TA, Shi QH, Stucky GD. Oxide hemostatic activity. J. Am. Chem. Soc 2006a;128:8384-8385. [PubMed: 16802788]

Ostomel TA, Shi QH, Tsung CK, Liang HJ, Stucky GD. Spherical bioactive glass with enhanced rates of hydroxyapatite deposition and hemostatic activity. Small 2006b;2:1261-1265. [PubMed: 17192971]

Ostomel TA, Stoimenov PK, Holden PA, Alam HB, Stucky GD. Hostguest composites for induced hemostasis and therapeutic healing in traumatic injuries. J. Thromb. Thrombol 2006c;22:55-67.

Pagona G, Tagmatarchis N. Carbon nanotubes: materials for medicinal chemistry and biotechnological applications. Curr. Med. Chem 2006;13:1789-1798. [PubMed: 16787221]

Palmer AE, Jin C, Reed JC, Tsien RY. Bcl-2-mediated alterations in endoplasmic reticulum $\mathrm{Ca}^{2+}$ analyzed with an improved genetically encoded fluorescent sensor. Proc. Natl. Acad. Sci. U.S.A 2004;101:17404-17409. [PubMed: 15585581]

Palmieri A, Brunelli G, Guerzoni L, Lo Muzio L, Scarano A, Rubini C, Scapoli L, Martinelli M, Pezzetti F, Carinci F. Comparison between titanium and anatase miRNAs regulation. Nanomed. Nanotechnol. Biol. Med 2007;3:138-143.

Pankhurst QA, Connolly J, Jones SK, Dobson J. Applications of magnetic nanoparticles in biomedicine. J. Phys. D: Appl. Phys 2003;36:R167-R181.

Park CH, Kim SH, Choi W, Lee YJ, Kim JS, Kang SS, Suh YH. Novel anticholinesterase and antiamnesic activities of dehydroevodiamine, a constituent of Evodia rutaecarpa. Planta Med 1996;62:405-409. [PubMed: 8923803]

Park CH, Lee YJ, Lee SH, Choi SH, Kim HS, Jeong SJ, Kim SS, Suh YH. Dehydroevodiamine HCl prevents impairment of learning and memory and neuronal loss in rat models of cognitive disturbance. J. Neurochem 2000;74:244-253. [PubMed: 10617126]

Park J, Bauer S, von der Mark K, Schmuki P. Nanosize and vitality: $\mathrm{TiO}_{2}$ nanotube diameter directs cell fate. Nano Lett 2007;7:1686-1691. [PubMed: 17503870]

Park JW, Vahidi B, Taylor AM, Rhee SW, Jeon NL. Microfluidic culture platform for neuroscience research. Nat. Protoc 2006;1:2128-2136. [PubMed: 17487204]

Park S, Lim J-H, Chung S-W, Mirkin CA. Self-assembly of mesoscopic metal-polymer amphiphiles. Science 2004;303:348-351. [PubMed: 14726585]

Park SY, Lytton-Jean AKR, Lee B, Weigand S, Schatz GC, Mirkin CA. DNA-programmable nanoparticle crystallization. Nature 2008;451:553-556. [PubMed: 18235497]

Patil S, Sandberg A, Heckert E, Self W, Seal S. Protein adsorption and cellular uptake of cerium oxide nanoparticles as a function of zeta potential. Biomaterials 2007;28:4600-4607. [PubMed: 17675227]

Pellegrini M, Obrien TJ, Hoy J, Sedal L. Mycoplasma pneumoniae infection associated with an acute brainstem syndrome. Acta Neurol. Scand 1996;93:203-206. [PubMed: 8741144]

Pellegrino T, Kudera S, Liedl T, Javier AM, Manna L, Parak WJ. On the development of colloidal nanoparticles towards multifunctional structures and their possible use for biological applications. Small 2005;1:48-63. [PubMed: 17193348]

Petersen H, Fechner PM, Martin AL, Kunath K, Stolnik S, Roberts CJ, Fischer D, Davies MC, Kissel T. Polyethylenimine-graft-poly(ethylene glycol) copolymers: influence of copolymer block structure 
on DNA complexation and biological activities as gene delivery system. Bioconj. Chem 2002;13:845-854.

Petropoulos AE, Schaffer BK, Cheney ML, Enochs S, Zimmer C, Weissleder R. MR-imaging of neuronal transport in the guinea-pig facial-nerve-initial findings. Acta Oto-Laryngol 1995;115:512-516.

Pisanic TR, Blackwell JD, Shubayev VI, Finones RR, Jin S. Nanotoxicity of iron oxide nanoparticle internalization in growing neurons. Biomaterials 2007;28:2572-2581. [PubMed: 17320946]

Prato M. [60] Fullerene chemistry for materials science applications. J. Mater. Chem 1997;7:1097-1109.

Priester JH, Horst AM, Van De Werfhorst LC, Saleta JL, Mertes LAK, Holden PA. Enhanced visualization of microbial biofilms by staining and environmental scanning electron microscopy. J. Microbiol. Methods 2007;68:577-587. [PubMed: 17196692]

Radloff C, Vaia RA, Brunton J, Bouwer GT, Ward VK. Metal nanoshell assembly on a virus bioscaffold. Nano Lett 2005;5:1187-1191. [PubMed: 15943466]

Radu DR, Lai CY, Jeftinija K, Rowe EW, Jeftinija S, Lin VSY. A polyamidoamine dendrimer-capped mesoporous silica nanosphere-based gene transfection reagent. J. Am. Chem. Soc 2004;126:1321613217. [PubMed: 15479063]

Rajh T, Chen LX, Lukas K, Liu T, Thurnauer MC, Tiede DM. Surface restructuring of nanoparticles: an efficient route for ligand-metal oxide cross-talk. J. Phys. Chem. B 2002;106:10543-10552.

Ramires PA, Cosentino F, Milella E, Torricelli P, Giavaresi G, Giardino R. In vitro response of primary rat osteoblasts to titania/hydroxyapatite coatings compared with transformed human osteoblast-like cells. J. Mater. Sci. Mater. Med 2002;13:797-801. [PubMed: 15348568]

Razin S. Mycoplasmas. Microbiol. Rev 1978;42:414-470. [PubMed: 353482]

Razin S, Yogev D, Naot Y. Molecular biology and pathogenicity of mycoplasmas. Microbiol. Mol. Biol. Rev 1998;62:1094-1156. [PubMed: 9841667]

Rieter WJ, Kim JS, Taylor KML, An HY, Lin WL, Tarrant T, Lin WB. Hybrid silica nanoparticles for multimodal imaging. Angew. Chem. Int. Ed 2007a;46:3680-3682.

Rieter WJ, Taylor KML, An H, Lin W, Lin W. Nanoscale metal-organic frameworks as potential multimodal contrast enhancing agents. J. Am. Chem. Soc 2006;128:9024-9025. [PubMed: 16834362]

Rieter WJ, Taylor KML, Lin W. Surface modification and functionalization of nanoscale metal-organic frameworks for controlled release and luminescence sensing. J. Am. Chem. Soc 2007b;129:98529853. [PubMed: 17645339]

Rinzler AG, Liu J, Dai H, Nikolaev P, Huffman CB, Rodriguez-Macias FJ, Boul PJ, Lu AH, Heymann D, Colbert DT, Lee RS, Fischer JE, Rao AM, Eklund PC, Smalley RE. Large-scale purification of single-wall carbon nanotubes: process, product, and characterization. Appl. Phys. A 1998;67:29_ 37.

Rock JP, Parsa AT, Rutka JT. Imaging, distribution, and toxicity of superparamagnetic iron oxide magnetic resonance nanoparticles in the rat brain and intracerebral tumor-comments. Neurosurgery 2005;57:796-1796.

Roney C, Kulkarni P, Arora V, Antich P, Bonte F, Wu AM, Mallikarjuana NN, Manohar S, Liang HF, Kulkarni AR, Sung HW, Sairam M, Aminabhavi TM. Targeted nanoparticles for drug delivery through the blood—brain barrier for Alzheimer's disease. J. Control. Release 2005;108:193-214. [PubMed: 16246446]

Rosi NL, Giljohann DA, Thaxton CS, Lytton-Jean AKR, Han MS, Mirkin CA. Oligonucleotide-modified gold nanoparticles for intracellular gene regulation. Science 2006;312:1027-1030. [PubMed: 16709779]

Rottem S, Barile MF. Beware of mycoplasmas. Trends Biotechnol 1993;11:143-151. [PubMed: 7763647]

Rouquerol J, Avnir D, Fairbridge CW, Everett DH, Haynes JH, Pernicone N, Ramsay JDF, Sing KSW, Unger KK. Recommendations for the characterization of porous solids. Pure Appl. Chem 1994;66:1739-1758.

Roy SC, Paulose M, Grimes CA. The effect of $\mathrm{TiO}_{2}$ nanotubes in the enhancement of blood clotting for the control of hemorrhage. Biomaterials 2007;28:4667-4672. [PubMed: 17692372]

Rubakhin SS, Garden RW, Fuller RR, Sweedler JV. Measuring the peptides in individual organelles with mass spectrometry. Nat. Biotechnol 2000;18:172-175. [PubMed: 10657123] 
Rubakhin SS, Greenough WT, Sweedler JV. Spatial profiling with MALDI MS: distribution of neuropeptides within single neurons. Anal. Chem 2003;75:5374-5380. [PubMed: 14710814]

Rubakhin SS, Sweedler JV. Characterizing peptides in individual mammalian cells using mass spectrometry. Nat. Protoc 2007;2:1987-1997. [PubMed: 17703210]

Sakaguchi K, Matsui M, Mizukami F. Applications of zeolite inorganic composites in biotechnology: current state and perspectives. Appl. Microbiol. Biotech 2005;67:306-311.

Salem AK, Searson PC, Leong KW. Multifunctional nanorods for gene delivery. Nat. Mater 2003;2:668671. [PubMed: 12970757]

Samori B, Zuccheri G. DNA codes for nanoscience. Angew. Chem. Int. Ed 2005;44:1166-1181.

Sanchez C, Lebeau B, Chaput F, Boilot JP. Optical properties of functional hybrid organic-inorganic nanocomposites. Adv. Mater 2003;15:1969-1994.

Sano N, Akazawa H, Kikuchi T, Kanki T. Separated synthesis of iron-included carbon nanocapsules and nanotubes by pyrolysis of ferrocene in pure hydrogen. Carbon 2003;41:2159-2162.

Santra S, Bagwe RP, Dutta D, Stanley JT, Walter GA, Tan W, Moudgil BM, Mericle RA. Synthesis and characterization of fluorescent, radio-opaque, and paramagnetic silica nanoparticles for multimodal bioimaging applications. Adv. Mater 2005a;17:2165-2169.

Santra S, Dutta D, Walter GA, Moudgil BM. Fluorescent nanoparticle probes for cancer imaging. Technol. Cancer Res. Treat 2005b;4:593-602. [PubMed: 16292879]

Santra S, Yang HS, Holloway PH, Stanley JT, Mericle RA. Synthesis of water-dispersible fluorescent, radio-opaque, and paramagnetic CdS:Mn/ZnS quantum dots: a multifunctional probe for bioimaging. J. Am. Chem. Soc 2005c;127:1656-1657. [PubMed: 15700997]

Sarikaya M, Tamerler C, Jen AKY, Schulten K, Baneyx F. Molecular biomimetics: nanotechnology through biology. Nat. Mater 2003;2:577-585. [PubMed: 12951599]

Sassolas A, Leca-Bouvier BD, Blum LJ. DNA biosensors and microarrays. Chem. Rev 2008;108:109139. [PubMed: 18095717]

Satishkumar BC, Govindaraj A, Rao CNR. Bundles of aligned carbon nanotubes obtained by the pyrolysis of ferrocene-hydrocarbon mixtures: role of the metal nanoparticles produced in situ. Chem. Phys. Lett 1999;307:158-162.

Satoh M, Takayanag I. Pharmacological studies on Fullerene(C-60), a novel carbon allotrope, and its derivatives. J. Pharmacol. Sci 2006;100:513-518. [PubMed: 16682790]

Sayes CM, Gobin AM, Ausman KD, Mendez J, West JL, Colvin VL. Nano-C-60 cytotoxicity is due to lipid peroxidation. Biomaterials 2005;26:7587-7595. [PubMed: 16005959]

Sayes CM, Wahi R, Kurian PA, Liu YP, West JL, Ausman KD, Warheit DB, Colvin VL. Correlating nanoscale titania structure with toxicity: a cytotoxicity and inflammatory response study with human dermal fibroblasts and human lung epithelial cells. Toxicol. Sci 2006;92:174-185. [PubMed: 16613837]

Schiffelers RM, Ansari A, Xu J, Zhou Q, Tang QQ, Storm G, Molema G, Lu PY, Scaria PV, Woodle MC. Cancer siRNA therapy by tumor selective delivery with ligand-targeted sterically stabilized nanoparticle. Nucleic Acids Res 2004;32:10.

Schmidt-Winkel P, Lukens WW, Zhao DY, Yang PD, Chmelka BF, Stucky GD. Mesocellular siliceous foams with uniformly sized cells and windows. J. Am. Chem. Soc 1999;121:254-255.

Schubert D, Dargusch R, Raitano J, Chan SW. Cerium and yttrium oxide nanoparticles are neuroprotective. Biochem. Biophys. Res. Commun 2006;342:86-91. [PubMed: 16480682]

Seeman NC. DNA in a material world. Nature 2003;421:427-431. [PubMed: 12540916]

Seeman NC. From genes to machines: DNA nanomechanical devices. Trends Biochem. Sci 2005;30:119125. [PubMed: 15752983]

Seferos DS, Giljohann DA, Rosi NL, Mirkin CA. Locked nucleic acidnanoparticle conjugates. ChemBioChem 2007;8:1230-1232. [PubMed: 17562553]

Shamah SM, Healy JM, Cload ST. Complex target SELEX. Acc. Chem. Res 2008;41:130-138. [PubMed: 18193823]

Shankar SS, Ahmad A, Pasricha R, Sastry M. Bioreduction of chloroaurate ions by geranium leaves and its endophytic fungus yields gold nanoparticles of different shapes. J. Mater. Chem 2003;13:18221826. 
Shaw SY, Westly EC, Pittet MJ, Subramanian A, Schreiber SL, Weissleder R. Perturbational profiling of nanomaterial biologic activity. Proc. Natl. Acad. Sci. U.S.A 2008;105:7387-7392. [PubMed: 18492802]

Shvedova AA, Castranova V, Kisin ER, Schwegler-Berry D, Murray AR, Gandelsman VZ, Maynard A, Baron P. Exposure to carbon nanotube material: assessment of nanotube cytotoxicity using human keratinocyte cells. J. Toxicol. Environ. Health. A 2003;66:1909-1926. [PubMed: 14514433]

Silva GA. Nanotechnology approaches for the regeneration and neuroprotection of the central nervous system. Surg. Neurol 2005;63:301-306. [PubMed: 15808703]

Silva GA. Neuroscience nanotechnology: progress, opportunities and challenges. Nat. Rev. Neurosci 2006;7:65-74. [PubMed: 16371951]

Simberg D, Duza T, Park JH, Essler M, Pilch J, Zhang LL, Derfus AM, Yang M, Hoffman RM, Bhatia S, Sailor MJ, Ruoslahti E. Biomimetic amplification of nanoparticle homing to tumors. Proc. Natl. Acad. Sci. U.S.A 2007;104:932-936. [PubMed: 17215365]

Simonetti AB, Englert GE, Campos K, Mergener M, de David C, de Oliveira AP, Roehe PM. Nanobacteria-like particles: a threat to cell cultures. Braz. J. Microbiol 2007;38:153-158.

Sinani VA, Koktysh DS, Yun BG, Matts RL, Pappas TC, Motamedi M, Thomas SN, Kotov NA. Collagen coating promotes biocompatibility of semiconductor nanoparticles in stratified LBL films. Nano Lett 2003;3:1177-1182.

Singh N, Liang CY, Rzigalinski B. Antioxidant properties of cerium oxide nanoparticles. Free Radic. Biol. Med 2006a;41:S152-S1152.

Singh R, Pantarotto D, Lacerda L, Pastorin G, Klumpp C, Prato M, Bianco A, Kostarelos K. Tissue biodistribution and blood clearance rates of intravenously administered carbon nanotube radiotracers. Proc. Nat. Acad. Sci 2006b;103:3357-3362. [PubMed: 16492781]

Slowing II, Trewyn BG, Giri S, Lin VSY. Mesoporous silica nanoparticles for drug delivery and biosensing applications. Adv. Func. Mater 2007;17:1225-1236.

Sokolova V, Kovtun A, Prymak O, Meyer-Zaika W, Kubareva EA, Romanova EA, Oretskaya TS, Heumann R, Epple M. Functionalisation of calcium phosphate nanoparticles by oligonucleotides and their application for gene silencing. J. Mater. Chem 2007;17:721-727.

Son SJ, Bai X, Nan A, Ghandehari H, Lee SB. Template synthesis of multifunctional nanotubes for controlled release. J. Control. Release 2006;114:143-152. [PubMed: 16870299]

Song CX, Labhasetwar V, Murphy H, Qu X, Humphrey WR, Shebuski RJ, Levy RJ. Formulation and characterization of biodegradable nanoparticles for intravascular local drug delivery. J. Control. Release 1997;43:197-212.

Song HT, Choi JS, Huh YM, Kim S, Jun YW, Suh JS, Cheon J. Surface modulation of magnetic nanocrystals in the development of highly efficient magnetic resonance probes for intracellular labeling. J. Am. Chem. Soc 2005;127:9992-9993. [PubMed: 16011350]

Soto K, Garza KM, Murr LE. Cytotoxic effects of aggregated nanomaterials. Acta Biomater 2007;3:351358. [PubMed: 17275430]

Soto KF, Carrasco A, Powell TG, Garza KM, Murr LE. Comparative in vitro cytotoxicity assessment of some manufactured nanoparticulate materials characterized by transmission electron microscopy. J. Nanopart. Res 2005;7:145-169.

Spagnou S, Miller AD, Keller M. Lipidic carriers of siRNA: differences in the formulation, cellular uptake, and delivery with plasmid DNA. Biochemistry 2004;43:13348-13356. [PubMed: 15491141]

Stoltenburg R, Reinemann C, Strehlitz B. SELEX-A (r)evolutionary method to generate high-affinity nucleic acid ligands. Biomol. Eng 2007;24:381-403. [PubMed: 17627883]

Strawn ET, Cohen CA, Rzigalinski BA. Cerium oxide nanoparticles increase lifespan and protect against free radical-mediated toxicity. FASEB J 2006;20:A1356-A11356.

Suh WH, Jang AR, Lee CS, Suh YH, Suslick KS. Endocytosis of magnetic microspheres into cells. Microsc. Microanal 2006a;S-02:620-621.

Suh WH, Jang AR, Suh YH, Suslick KS. Porous, hollow, and ball-in-ball metal oxide microspheres: preparation, endocytosis, and cytotoxicity. Adv. Mater 2006b;18:1832-1837.

Suh WH, Suslick KS, Suh Y-H. Therapeutic agents for Alzheimer's disease. Curr. Med. Chem.: Cent. Nerv. Sys. Agen 2005;5:259-269. 
Suh YH, Checler F. Amyloid precursor protein, presenilins, and alphasynuclein: molecular pathogenesis and pharmacological applications in Alzheimer's disease. Pharmacol. Rev 2002;54:469-525. [PubMed: 12223532]

Sui J, Tleugabulova D, Brennan JD. Direct and indirect monitoring of peptide-silica interactions using time-resolved fluorescence anisotropy. Langmuir 2005;21:4996-5001. [PubMed: 15896042]

Sun J, DuFort C, Daniel MC, Murali A, Chen C, Gopinath K, Stein B, De M, Rotello VM, Holzenburg A, Kao CC, Dragnea B. Core-controlled polymorphism in virus-like particles. Proc. Natl. Acad. Sci. U.S.A 2007;104:1354-1359. [PubMed: 17227841]

Suslick KS, Grinstaff MW. Protein microencapsulation of nonaqueous liquids. J. Am. Chem. Soc 1990;112:7807-7809.

Swan EEL, Popat KC, Desai TA. Peptide-immobilized nanoporous alumina membranes for enhanced osteoblast adhesion. Biomaterials 2005a;26:1969-1976. [PubMed: 15576171]

Swan EEL, Popat KC, Grimes CA, Desai TA. Fabrication and evaluation of nanoporous alumina membranes for osteoblast culture. J. Biomed. Mater. Res. Part A 2005b;72A:288-295.

Sykova E, Jendelova P. Migration, fate and in vivo imaging of adult stem cells in the CNS. Cell Death Differ 2007;14:1336-1342. [PubMed: 17396130]

Takayama S, McDonald JC, Ostuni E, Liang MN, Kenis PJA, Ismagilov RF, Whitesides GM. Patterning cells and their environments using multiple laminar fluid flows in capillary networks. Proc. Natl. Acad. Sci. U.S.A 1999;96:5545-5548. [PubMed: 10318920]

Tang GP, Zeng JM, Gao SJ, Ma YX, Shi L, Li Y, Too HP, Wang S. Polyethylene glycol modified polyethylenimine for improved CNS gene transfer: effects of PEGylation extent. Biomaterials 2003;24:2351-2362. [PubMed: 12699673]

Tang ZY, Kotov NA. One-dimensional assemblies of nanoparticles: preparation, properties, and promise. Adv. Mater 2005;17:951-962.

Tansil NC, Gao ZQ. Nanoparticles in biomolecular detection. Nano Today 2006;1:28-37.

Tarnuzzer RW, Colon J, Patil S, Seal S. Vacancy engineered ceria nanostructures for protection from radiation-induced cellular damage. Nano Lett 2005;5:2573-2577. [PubMed: 16351218]

Taylor AM, Blurton-Jones M, Rhee SW, Cribbs DH, Cotman CW, Jeon NL. A microfluidic culture platform for CNS axonal injury, regeneration and transport. Nat. Methods 2005;2:599-605. [PubMed: 16094385]

Taylor JR, Fang MM, Nie SM. Probing specific sequences on single DNA molecules with bioconjugated fluorescent nanoparticles. Anal. Chem 2000;72:1979-1986. [PubMed: 10815954]

Terrones M, Grobert N, Olivares J, Zhang JP, Terrones H, Kordatos K, Hsu WK, Hare JP, Townsend PD, Prassides K, Cheetham AK, Kroto HW, Walton DRM. Controlled production of alignednanotube bundles. Nature 1997;388:52-55.

Thess A, Lee R, Nikolaev P, Dai HJ, Petit P, Robert J, Xu CH, Lee YH, Kim SG, Rinzler AG, Colbert DT, Scuseria GE, Tomanek D, Fischer JE, Smalley RE. Crystalline ropes of metallic carbon nanotubes. Science 1996;273:483-487. [PubMed: 8662534]

Thill A, Zeyons O, Spalla O, Chauvat F, Rose J, Auffan M, Flank AM. Cytotoxicity of $\mathrm{CeO}_{2}$ nanoparticles for Escherichia coli. Physico-chemical insight of the cytotoxicity mechanism. Environ. Sci. Tech 2006;40:6151-6156.

Thorek DLJ, Chen A, Czupryna J, Tsourkas A. Superparamagnetic iron oxide nanoparticle probes for molecular imaging. Ann. Biomed. Eng 2006;34:23-38. [PubMed: 16496086]

Tischer, W.; Wedekind, F. Biocatalysis: From Discovery to Application. Vol. vol. 200. Springer-Verlag; 1999. Immobilized enzymes : methods and applications. Boehringer Mannheim GmbH, Penzberg, Germany. Topics in Current Chemistry; p. 95-126.CODEN: TPCCAQ, ISSN: 0340-1022

Tominaga H, Ishiyama M, Ohseto F, Sasamoto K, Hamamoto T, Suzuki K, Watanabe M. A water-soluble tetrazolium salt useful for colorimetric cell viability assay. Anal. Commun 1999;36:47-50.

Torney F, Trewyn BG, Lin VSY, Wang K. Mesoporous silica nanoparticles deliver DNA and chemicals into plants. Nat. Nanotechnol 2007;2:295-300. [PubMed: 18654287]

Trovarelli A. Catalytic properties of ceria and $\mathrm{CeO}_{2}$-containing materials. Catal. Rev.: Sci. Eng 1996;38:439-520. 
Tsay JM, Michalet X. New light on quantum dot cytotoxicity. Chem. Biol 2005;12:1159-1161. [PubMed: 16298294]

Tsiodras S, Kelesidis I, Kelesidis T, Stamboulis E, Giamarellou H. Central nervous system manifestations of Mycoplasma pneumoniae infections. J. Infect 2005;51:343-354. [PubMed: 16181677]

Tu RS, Tirrell M. Bottom-up design of biomimetic assemblies. Adv. Drug Deliv. Rev 2004;56:15371563. [PubMed: 15350288]

Turkez H, Geyikoglu F. An in vitro blood culture for evaluating the genotoxicity of titanium dioxide: the responses of antioxidant enzymes. Toxicol. Ind. Health 2007;23:19-23. [PubMed: 17722736]

The Nanotoxicology Research and Training Program. [(accessed October 2007)]. http://www.cnsi.ucla.edu/staticpages/education/nanotox-program

Underhill GH, Bhatia SN. High-throughput analysis of signals regulating stem cell fate and function. Curr. Opin. Chem. Biol 2007;11:357-366. [PubMed: 17656147]

Veiseh O, Sun C, Gunn J, Kohler N, Gabikian P, Lee D, Bhattarai N, Ellenbogen R, Sze R, Hallahan A, Olson J, Zhang MQ. Optical and MRI multifunctional nanoprobe for targeting gliomas. Nano Lett 2005;5:1003-1008. [PubMed: 15943433]

Vlasov YA, Bo XZ, Sturm JC, Norris DJ. On-chip natural assembly of silicon photonic bandgap crystals. Nature 2001;414:289-293. [PubMed: 11713524]

Voura EB, Jaiswal JK, Mattoussi H, Simon SM. Tracking metastatic tumor cell extravasation with quantum dot nanocrystals and fluorescence emissionscanning microscopy. Nature Med 2004;10:993-998. [PubMed: 15334072]

Wadghiri YZ, Sigurdsson EM, Sadowski M, Elliott JI, Li YS, Scholtzova H, Tang CY, Aguinaldo G, Pappolla M, Duff K, Wisniewski T, Turnbull DH. Detection of Alzheimer's amyloid in transgenic mice using magnetic resonance microimaging. Magn. Reson. Med 2003;50:293-302. [PubMed: 12876705]

Waites KB, Talkington DF. Mycoplasma pneumoniae and its role as a human pathogen. Clin. Microbiol. Rev 2004;17:697-728. [PubMed: 15489344]

Wang J. Nanomaterial-based amplified transduction of biomolecular interactions. Small 2005;1:10361043. [PubMed: 17193390]

Wang JJ, Sanderson BJS, Wang H. Cyto- and genotoxicity of ultrafine $\mathrm{TiO}_{2}$ particles in cultured human lymphoblastoid cells. Mutat. Res.: Genet. Toxicol. Environ. Mutagen 2007a;628:99-106.

Wang JX, Zhou GQ, Chen CY, Yu HW, Wang TC, Ma YM, Jia G, Gao YX, Li B, Sun J, Li YF, Jiao F, Zhao YL, Chai ZF. Acute toxicity and biodistribution of different sized titanium dioxide particles in mice after oral administration. Toxicol. Lett 2007b;168:176-185. [PubMed: 17197136]

Wang YXJ, Hussain SM, Krestin GP. Superparamagnetic iron oxide contrast agents: physicochemical characteristics and applications in MR imaging. Eur. Radiol 2001;11:2319-2331. [PubMed: 11702180]

Ware CB, Nelson AM, Blau CA. A comparison of NIH-approved human ESC lines. Stem Cells 2006;24:2677-2684. [PubMed: 16916927]

Warheit DB, Webb TR, Colvin VL, Reed KL, Sayes CR. Pulmonary bioassay studies with nanoscale and fine-quartz particles in rats: toxicity is not dependent upon particle size but on surface characteristics. Toxicol. Sci 2007;95:270-280. [PubMed: 17030555]

Warheit DB, Webb TR, Sayes CM, Colvin VL, Reed KL. Pulmonary instillation studies with nanoscale $\mathrm{TiO}_{2}$ rods and dots in rats: toxicity is not dependent upon particle size and surface area. Toxicol. Sci 2006;91:227-236. [PubMed: 16495353]

Wei GB, Jin QM, Giannobile WV, Ma PX. Nano-fibrous scaffold for controlled delivery of recombinant human PDGF-BB. J. Control. Release 2006;112:103-110. [PubMed: 16516328]

Wei GB, Pettway GJ, McCauley LK, Ma PX. The release profiles and bioactivity of parathyroid hormone from poly(lactic-co-glycolic acid) microspheres. Biomaterials 2004;25:345-352. [PubMed: 14585722]

Weibel DB, DiLuzio WR, Whitesides GM. Microfabrication meets microbiology. Nat. Rev. Microbiol 2007;5:209-218. [PubMed: 17304250]

Weissleder R, Kelly K, Sun EY, Shtatland T, Josephson L. Cell-specific targeting of nanoparticles by multivalent attachment of small molecules. Nat. Biotechnol 2005;23:1418-1423. [PubMed: 16244656] 
Weissleder R, Mahmood U. Molecular imaging. Radiology 2001;219:316-333. [PubMed: 11323453]

Weissleder R, Stark DD, Engelstad BL, Bacon BR, Compton CC, White DL, Jacobs P, Lewis J. Superparamagnetic iron-oxide—pharmacokinetics and toxicity. Am. J. Roentgenol 1989;152:167173. [PubMed: 2783272]

Wernette DP, Liu JW, Bohn PW, Lu Y. Functional-DNA-based nanoscale materials and devices for sensing trace contaminants in water. MRS Bull 2008;33:34-41.

What is carbon black?. [(accessed January 2008)]. http://carbon-black.org/what_is.html

Whitesides JG, Lamantia AS. Distinct adhesive behaviors of neurons and neural precursor cells during regional differentiation in the mammalian forebrain. Dev. Biol 1995;169:229-241. [PubMed: 7750641]

Wiesner MR. Responsible development of nanotechnologies for water and wastewater treatment. Water Sci. Technol 2006;53:45-51. [PubMed: 16605016]

Wigginton NS, Haus KL, Hochella MF. Aquatic environmental nanoparticles. J. Environ. Monit 2007;9:1306-1316. [PubMed: 18049768]

Wu PC, Wang WS, Huang YT, Sheu HS, Lo YW, Tsai TL, Shieh DB, Yeh CS. Porous iron oxide based nanorods developed as delivery nanocapsules. Chem. Eur. J 2007;13:3878-3885.

Xia T, Kovochich M, Brant J, Hotze M, Sempf J, Oberley T, Sioutas C, Yeh JI, Wiesner MR, Nel AE. Comparison of the abilities of ambient and manufactured nanoparticles to induce cellular toxicity according to an oxidative stress paradigm. Nano Lett 2006a;6:1794-1807. [PubMed: 16895376]

Xia YD, Yang ZX, Mokaya R. Simultaneous control of morphology and porosity in nanoporous carbon: graphitic mesoporous carbon nanorods and nanotubules with tunable pore size. Chem. Mater 2006b; 18:140-148.

$\mathrm{Xu}$ CJ, Sun SH. Monodisperse magnetic nanoparticles for biomedical applications. Polymer Int 2007;56:821-826.

Xu CJ, Xu KM, Gu HW, Zhong XF, Guo ZH, Zheng RK, Zhang XX, Xu B. Nitrilotriacetic acid-modified magnetic nanoparticles as a general agent to bind histidine-tagged proteins. J. Am. Chem. Soc 2004;126:3392-3393. [PubMed: 15025444]

Yamamoto A, Honma R, Sumita M, Hanawa T. Cytotoxicity evaluation of ceramic particles of different sizes and shapes. J. Biomed. Mater. Res. Part A 2004;68A:244-256.

Yamawaki H, Iwai N. Cytotoxicity of water-soluble fullerene in vascular endothelial cells. Am. J. Physiol. Cell. Physiol 2006;290:C1495-C1502. [PubMed: 16407415]

Yan AH, Lau BW, Weissman BS, Kulaots I, Yang NYC, Kane AB, Hurt RH. Biocompatible, hydrophilic, supramolecular carbon nanoparticles for cell delivery. Adv. Mater 2006;18:2373-2378.

Yan JL, Estevez MC, Smith JE, Wang KM, He XX, Wang L, Tan WH. Dye-doped nanoparticles for bioanalysis. Nano Today 2007;2:44-50.

Yang PD, Deng T, Zhao DY, Feng PY, Pine D, Chmelka BF, Whitesides GM, Stucky GD. Hierarchically ordered oxides. Science 1998;282:2244-2246. [PubMed: 9856944]

Yang HS, Santra S, Walter GA, Holloway PH. Gd-III-functionalized fluorescent quantum dots as multimodal imaging probes. Adv. Mater 2006a;18:2890-2894.

Yang J, Lee C-H, Park J, Seo S, Lim E-K, Song YJ, Suh J-S, Yoon H-G, Huh Y-M, Haam S. Antibody conjugated magnetic PLGA nanoparticles for diagnosis and treatment of breast cancer. J. Mater. Chem 2007; 17:2695-2699.

Yang K, Zhu LZ, Xing BS. Adsorption of polycyclic aromatic hydrocarbons by carbon nanomaterials. Environ. Sci. Tech 2006b;40:1855-1861.

Yeo Y, Park K. A new microencapsulation method using an ultrasonic atomizer based on interfacial solvent exchange. J. Control. Release 2004;100:379-388. [PubMed: 15567503]

Ying JY, Mehnert CP, Wong MS. Synthesis and applications of supramolecular-templated mesoporous materials. Angew. Chem. Int. Ed 1999;38:56-77.

Yoon SB, Chai GS, Kang SK, Yu JS, Gierszal KP, Jaroniec M. Graphitized pitch-based carbons with ordered nanopores synthesized by using colloidal crystals as templates. J. Am. Chem. Soc 2005;127:4188-4189. [PubMed: 15783198]

Yoon SB, Sohn K, Kim JY, Shin CH, Yu JS, Hyeon T. Fabrication of carbon capsules with hollow macroporous core/mesoporous shell structures. Adv. Mater 2002;14:19-21. 
Yoshida K, Morita M, Mishina H. Cytotoxicity of metal and ceramic particles in different sizes. JSME Int. J. C: Mech. Syst 2003;46:1284-1289.

Yu SJ, Kang MW, Chang HC, Chen KM, Yu YC. Bright fluorescent nanodiamonds: no photobleaching and low cytotoxicity. J. Am. Chem. Soc 2005;127:17604-17605. [PubMed: 16351080]

Yuan XD, Li L, Rathinavelu A, Hao JS, Narasimhan M, He M, Heitlage V, Tam L, Viqar S, Salehi M. siRNA drug delivery by biodegradable polymeric nanoparticles. J. Nanosci. Nanotech 2006;6:2821-2828.

Z-Medica QuikClot. http://www.Z-medica.com/quikclot/index.asp

Z-Medica Quikclot Sport ${ }^{T M}$ Silver. http://www.Z-medica.com/products/quikclot_sport.asp

Zaremba CM, Belcher AM, Fritz M, Li YL, Mann S, Hansma PK, Morse DE, Speck JS, Stucky GD. Critical transitions in the biofabrication of abalone shells and flat pearls. Chem. Mater 1996;8:679690.

Zdravkov BD, Cermak JJ, Sefara M, Janku J. Pore classification in the characterization of porous materials: a perspective. Cent. Eur. J. Chem 2007;5:385-395.

Zhang SG, Yan L, Altman M, Lassle M, Nugent H, Frankel F, Lauffenburger DA, Whitesides GM, Rich A. Biological surface engineering: a simple system for cell pattern formation. Biomaterials 1999;20:1213-1220. [PubMed: 10395390]

Zhang TT, Stilwell JL, Gerion D, Ding LH, Elboudwarej O, Cooke PA, Gray JW, Alivisatos AP, Chen FF. Cellular effect of high doses of silica-coated quantum dot profiled with high throughput gene expression analysis and high content cellomics measurements. Nano Lett 2006;6:800-808. [PubMed: 16608287]

Zhang YJ, Wang SP, Eghtedari M, Motamedi M, Kotov NA. Inverted-colloidal-crystal hydrogel matrices as three-dimensional cell scaffolds. Adv. Func. Mater 2005;15:725-731.

Zhao DY, Feng JL, Huo QS, Melosh N, Fredrickson GH, Chmelka BF, Stucky GD. Triblock copolymer syntheses of mesoporous silica with periodic 50 to 300 angstrom pores. Science 1998a;279:548552. [PubMed: 9438845]

Zhao DY, Huo QS, Feng JL, Chmelka BF, Stucky GD. Nonionic triblock and star diblock copolymer and oligomeric surfactant syntheses of highly ordered, hydrothermally stable, mesoporous silica structures. J. Am. Chem. Soc 1998b;120:6024-6036.

Zhao XJ, Zhang SG. Molecular designer self-assembling peptides. Chem. Soc. Rev 2006;35:1105-1110. [PubMed: 17057839]

Zhelev Z, Ohba H, Bakalova R. Single quantum dot-micelles coated with silica shell as potentially noncytotoxic fluorescent cell tracers. J. Am. Chem. Soc 2006;128:6324-6325. [PubMed: 16683790]

Zheng M, Jagota A, Strano MS, Santos AP, Barone P, Chou SG, Diner BA, Dresselhaus MS, McLean RS, Onoa GB, Samsonidze GG, Semke ED, Usrey M, Walls DJ. Structure-based carbon nanotube sorting by sequence-dependent DNA assembly. Science 2003;302:1545-1548. [PubMed: 14645843]

Zhu L, Chang DW, Dai L, Hong Y. DNA damage induced by multiwalled carbon nanotubes in mouse embryonic stem cells. Nano Lett 2007;7:3592-3597. [PubMed: 18044946]

Zhu SQ, Oberdorster E, Haasch ML. Toxicity of an engineered nanoparticle (fullerene, C-60) in two aquatic species, Daphnia and fathead minnow. Mar. Environ. Res 2006;62:S5-S9. [PubMed: 16709433] 
(a)

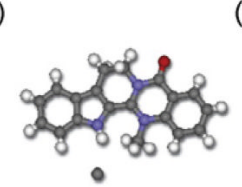

(b)

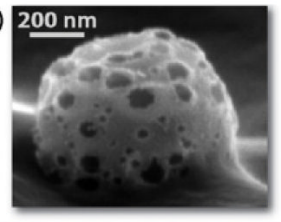

(c)

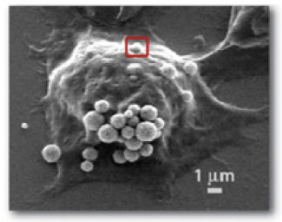

(d)

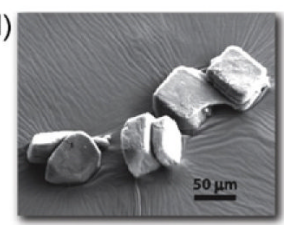

(e)

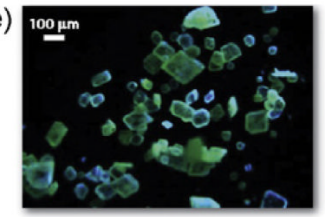

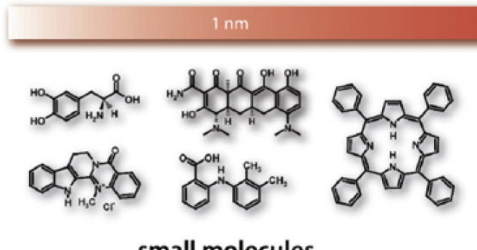

$10 \mathrm{~nm}$

$100 \mathrm{~nm}$

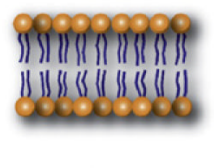

lipid bilayer

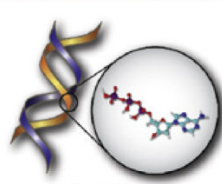

dsDNA

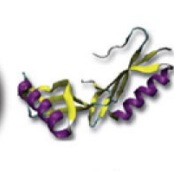

protein

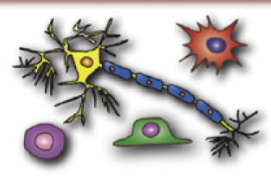

cells (e.g. neuron)

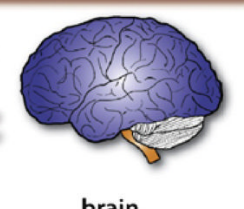

brain

biomolecules

Fig. 1.

The sizes of biologically relevant entities. (Top row above scale bar) From left to right: (a) Potent Alzheimer's disease candidate drug, dehydroevodiamine HCl (DHED) X-ray crystal structure, (b and c) porous metal oxide microspheres being endocytosed by BV2 microglia cell (close-up and low magnification) SEM images, (d and e) SEM and fluorescence micrograph of DHED microcrystals (DHED is blue-green luminscent). (Bottom row below the scale bar) Left to right: Small molecules, such as dopamine, minocycline, mefenamic acid, DHED, and heme, are $\sim 1 \mathrm{~nm}$ or smaller. The lipid bilayer is a few nanometers thick. A biomolecule such as a (22 bp) microRNA and a protein is only a few nanometers in size. A single cell or neuron is tens or hundreds of microns in size. Illustration of a human brain which is tens of centimeters in size. 
(a)

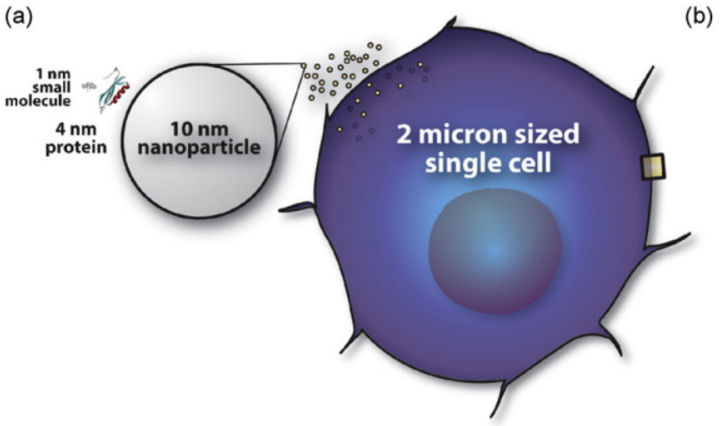

(b)

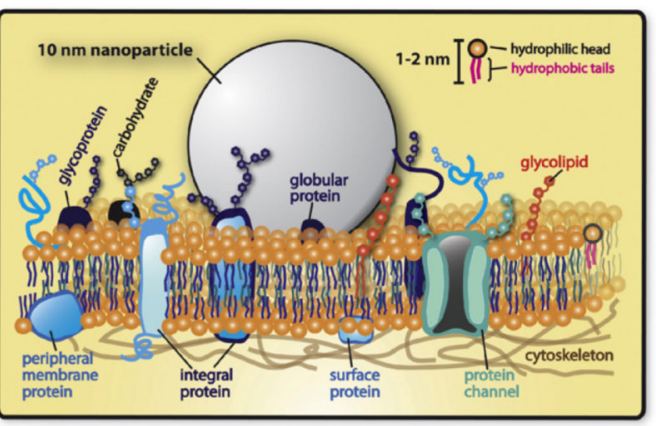

Fig. 2.

Size matters. (a) Compared to a $10 \mathrm{~nm}$ nanoparticle, proteins (e.g. APP; X-ray crystal structure obtained from www.pdb.org (Berman et al., 2000), protein ID 2FKL; visualization done by Accelrys Discovery Studio Visualization 1.7 software) and small molecules (e.g. DHED) are small in size and volume. A mammalian cell which is made up of proteins, nucleic acids, and other small to large molecules is thousand times larger in volume and size compared to a 10 $\mathrm{nm}$ nanoparticle. (b) Cell membrane incorporating various proteins and a single $10 \mathrm{~nm}$ nanoparticle. 


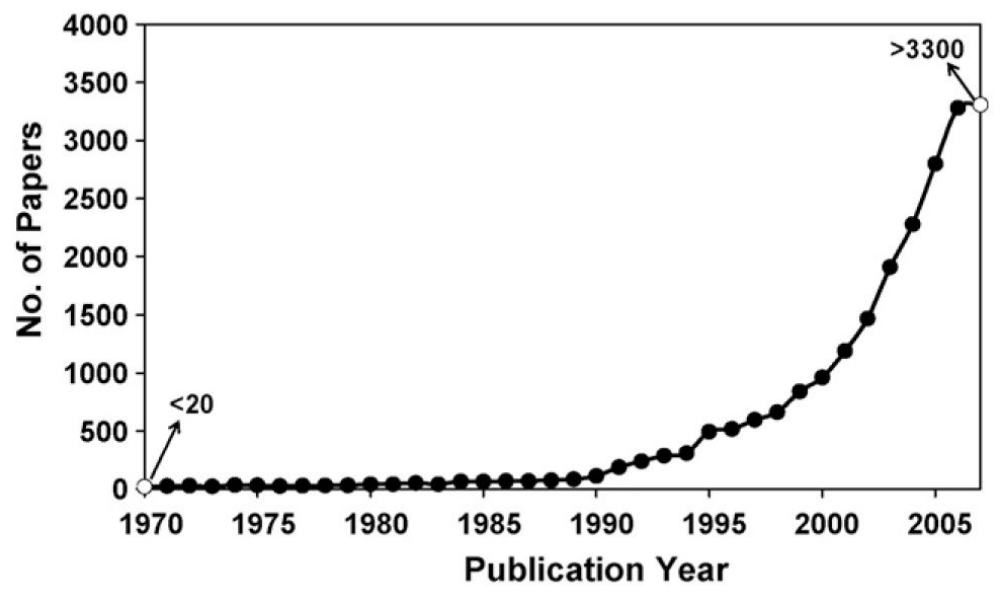

Fig. 3.

Published papers in nanomaterials synthesis papers published in 1970-2007. Number of publications was obtained from ISI Web of Science (one of Thomson Scientific databases and part of Web of Knowledge) using a combination of search terms that represent nanomaterial and synthesis. 


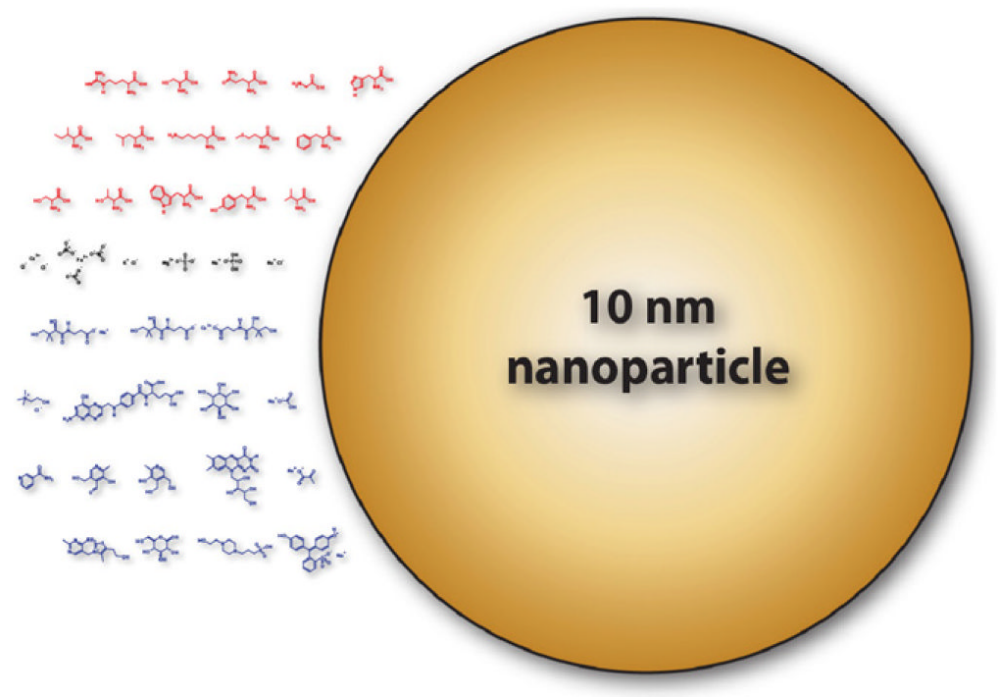

Fig. 4.

Contents of DMEM vs. $10 \mathrm{~nm}$ nanoparticle. Red chemical structures (first three rows) represent amino acids, black chemical structures (fourth row) represent inorganic salts, and blue structures (rows 5-8) represent vitamins and other small organic molecules. The contents information of DMEM (Dulbecco's Modified Eagle's Medium) were readily available on-line at various biochemical vendor websites such as HyClone and Sigma-Aldrich. 


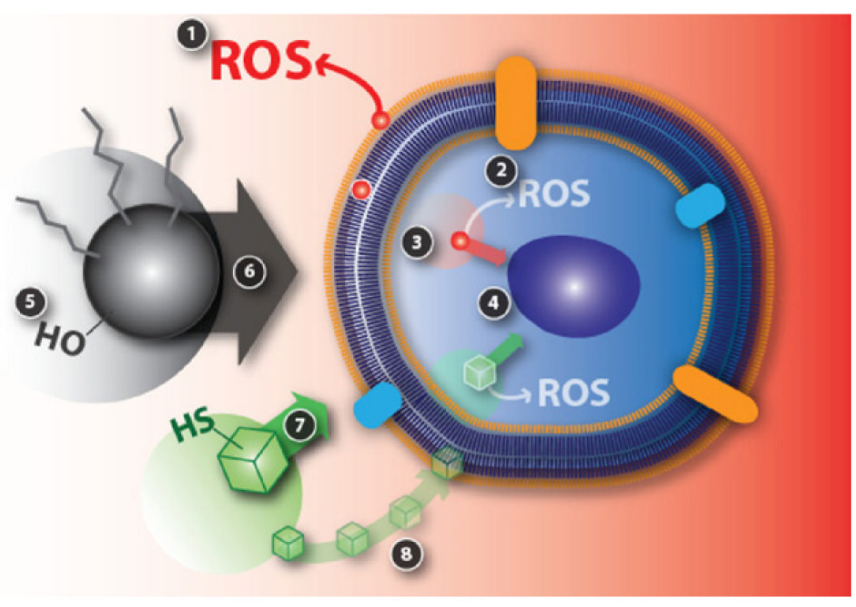

Fig. 5.

Cell and particle interactions. Toxicological effects of nanomaterials can be simplified into eight events as shown in the illustration above but limiting the interaction between a nanoparticle and a cell to eight events is an over simplification and the details of actual phenomena that are happening at the interfaces are very difficult to analyze and understand. (1) Reactive oxygen species products such as superoxide $\left({ }^{\circ} \mathrm{O}_{2}{ }^{-}\right)$and hydroxyl radical $\left({ }^{\circ} \mathrm{OH}\right)$ whether it is inside or outside can be key factors in nanostructured materials toxicological effects (Nel et al., 2006). Cell membrane integrity leading to cell survivability will be affected by ROS produced by a nanoparticle smaller than a cell (red particle) as shown. (2) Event 2 represents the situation where a nanoparticle is internalized and then creates ROS products (Nel et al., 2006). (3) Particle dissolution affecting cellular function after nanoparticle internalization is event 3 (Borm et al., 2006). (4) Event 4 represents any mechanical damage to sub-cellular units such as the lysosome, endoplasmic reticulum, and nucleus (Yamamoto et al., 2004). (5) Different functional groups and surface electronic structures arising from different nanostructured materials will determine the level of interaction between the nanoparticles and their surroundings which is represented by event 5 (Karakoti et al., 2006; Kostarelos et al., 2007). (6) Overall size of the particle can play an important role as represented by event 6 since large particles can potentially induce permanent damage to the cell membrane while small particles can pass through the membrane and do harm inside cell (Yoshida et al., 2003). (7) Non-spherical particles, on the other hand, might have a different biological response compared to the spherical nanoparticles which is shown as event 7 (Geng et al., 2007). (8) Event 8 represents dissolution characteristics of the nanomaterials outside the cell which can affect the cell in various ways (event 8) (Borm et al., 2006). 
polyelectrolyte

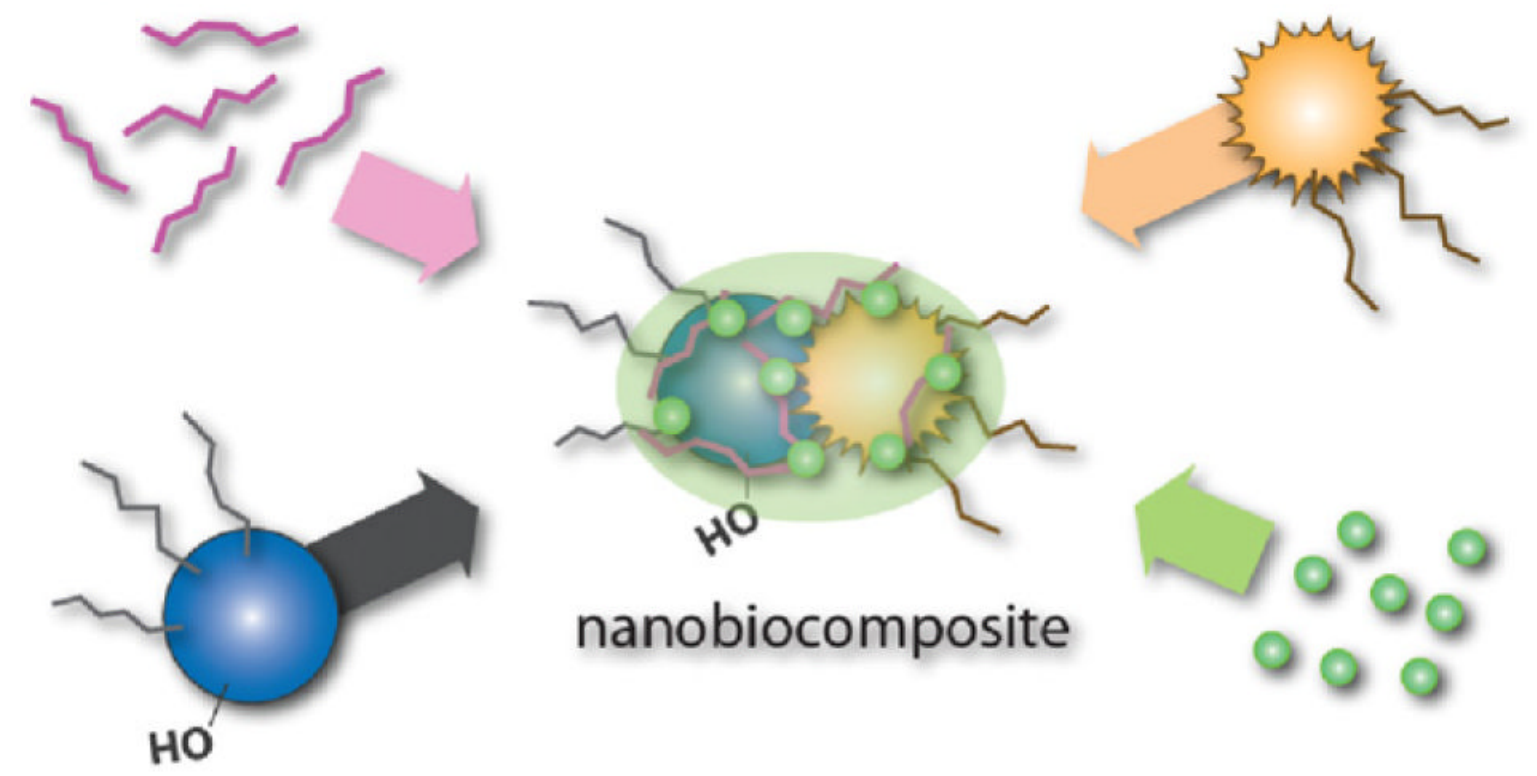

nanoparticle nanobacteria

soluble ionic species

Fig. 6.

Nanobiocomposite formed from a nanoparticle (sub-micron) and a nanobacteria (e.g. mycoplasma; sub-500 nm). This event is probable to happen under biogenic conditions where polyelectrolytes (e.g. peptide) and soluble ionic species (e.g. $\mathrm{Ca}^{2+}, \mathrm{Na}^{+}$) are readily available. Sub-micron engineered nanoparticles can form new composite materials with mycoplasma and the new nanobiocomposite material can have vastly different chemistries and physical properties which will lead to different biological properties. 


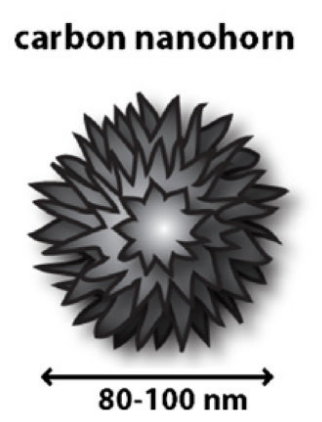

carbon nanodots

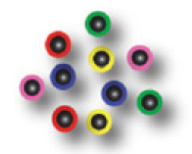

$<10 \mathrm{~nm}$

\section{diamond nanoparticles}

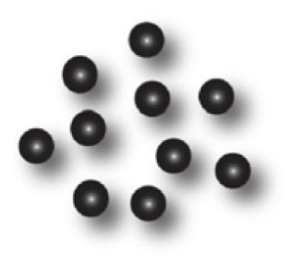

$<100 \mathrm{~nm}$

Fig. 7.

Spherical and non-tubular carbon nanomaterials. Sub-100 nm carbon nanoparticles that are other than $\mathrm{C}_{60}$ or carbon nanotubes will offer another set of tools for neuroscientist as well as other biologists. Illustrations were prepared based on data, schemes, and figures appearing in the references with permission from the publisher. 

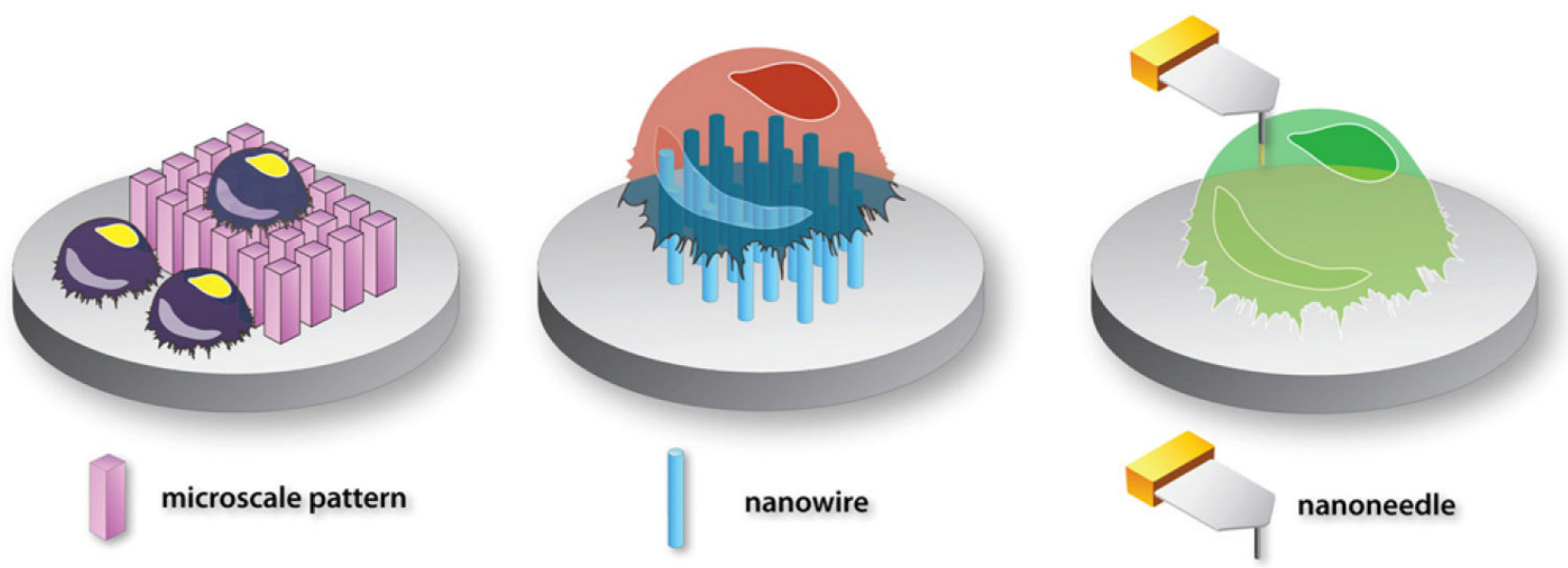

Fig. 8.

Controlling cell function by microscale patterns and nanowires. Details are provided for the top three illustrations in the maintext. Making sub-micron patterns as well as functionalizing the sub-patterns with unique nanostructures such as wires and pores will be very interesting to utilize in neuroscience, especially studying interacting neurons and neuronal implants in vivo. 

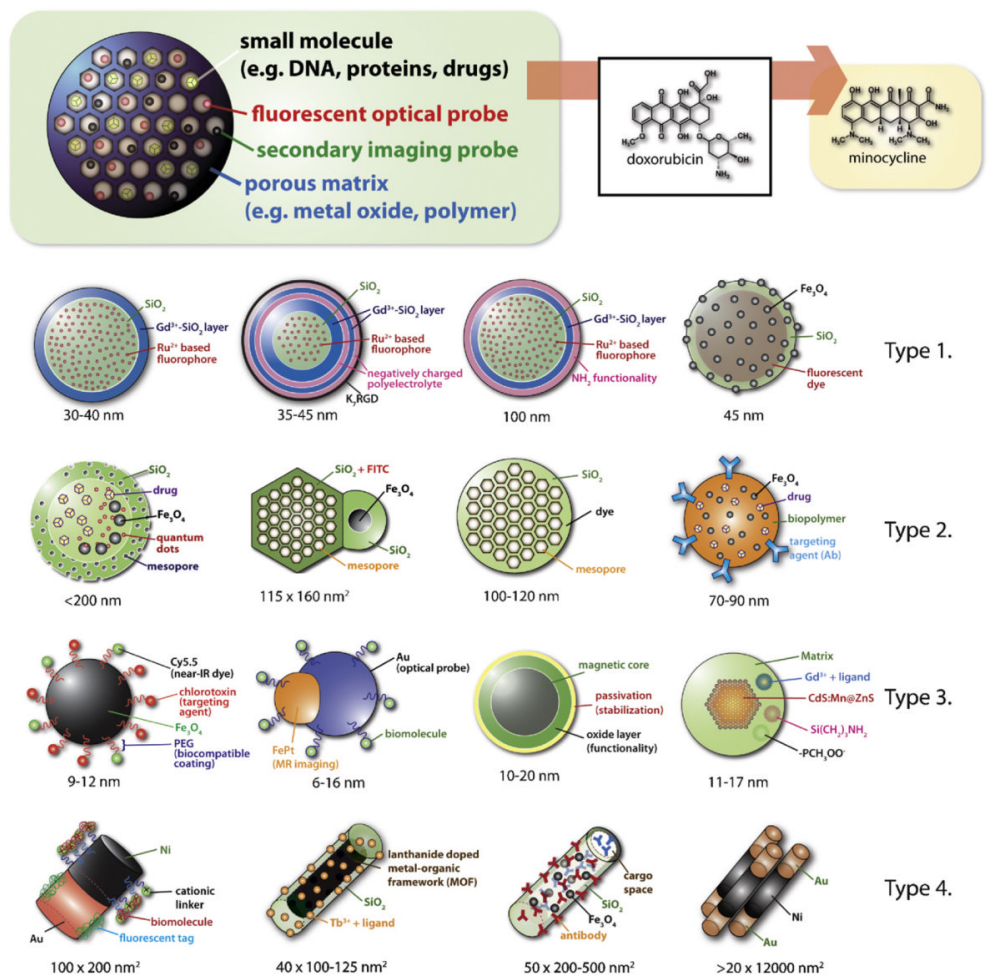

Type 4.

Fig. 9.

Multifunctional nanoparticle systems (MFNPS) for biomedical applications. MFNPSs can be divided into four distinctive types. Type 1 is non-porous but spherical $\mathrm{SiO}_{2}$ based sub-100 nm nanoparticles with two or more components. Type 2 is sub-200 nm spherical nanoparticles that is either porous or can incorporate and, in time, release small molecules such as drug molecules. Type 3 is sub-20 nm nanoparticles with functionalizable ligands or biomolecules stabilized (passivated) onto the nanoparticles and are, in most cases, first synthesized in organic conditions which offer good size control and then phase exchanged to become dispersable in aqueous media. Finally, type 4 is non-spherical nanoparticle systems that have multiple components such as fluorescent tags and antibodies. Illustrations were prepared based on data, schemes, and figures appearing in the references of Table 5 with permission. 


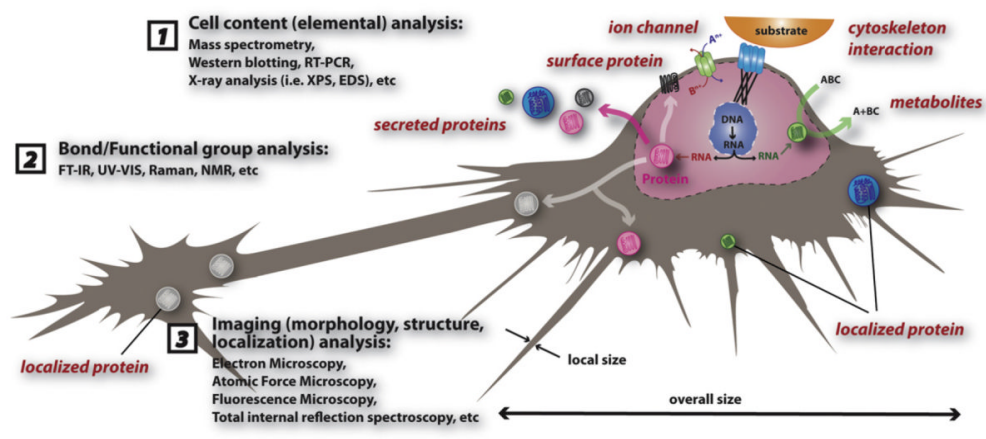

Fig. 10.

Analysis of a cell. Sub-components of a cell include (but not exclusive) nucleic acids, membrane fractions, proteins (e.g. secreted, surface displaying, localized), ion channels, and cytoskeletal components. Considering the nature of such sub-cellular components and products three categories of analyses can be drawn: (1) cell content (elemental) analysis, (2) chemical bond/functional group analysis, (3) imaging (morphology, structure, localization) analysis. 


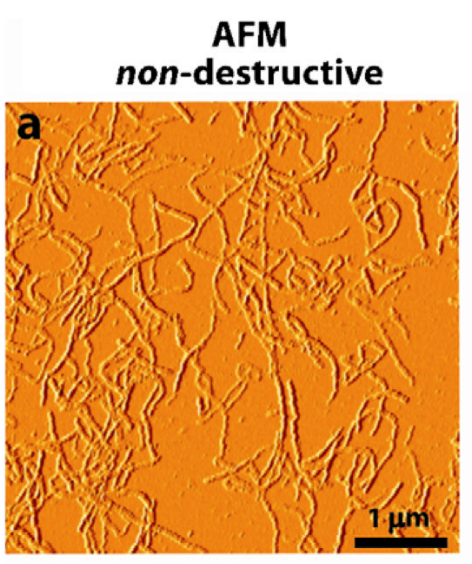

\section{Electron Microscopy destructive}

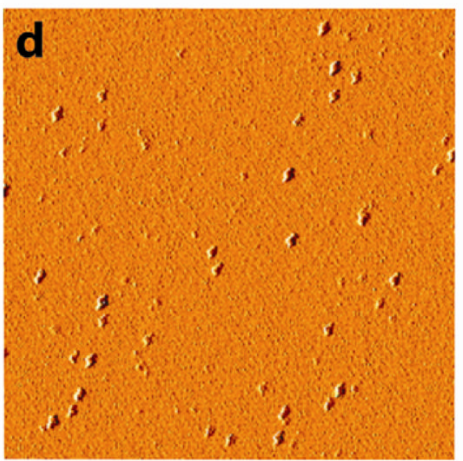

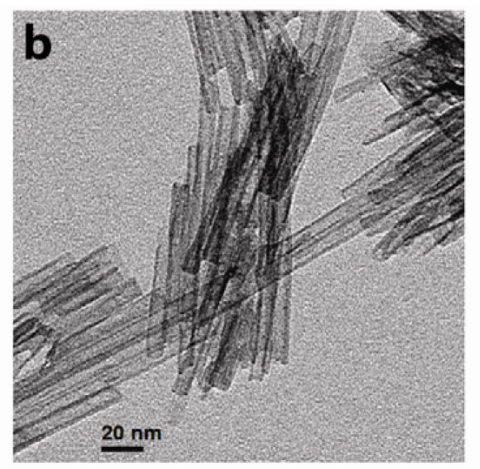
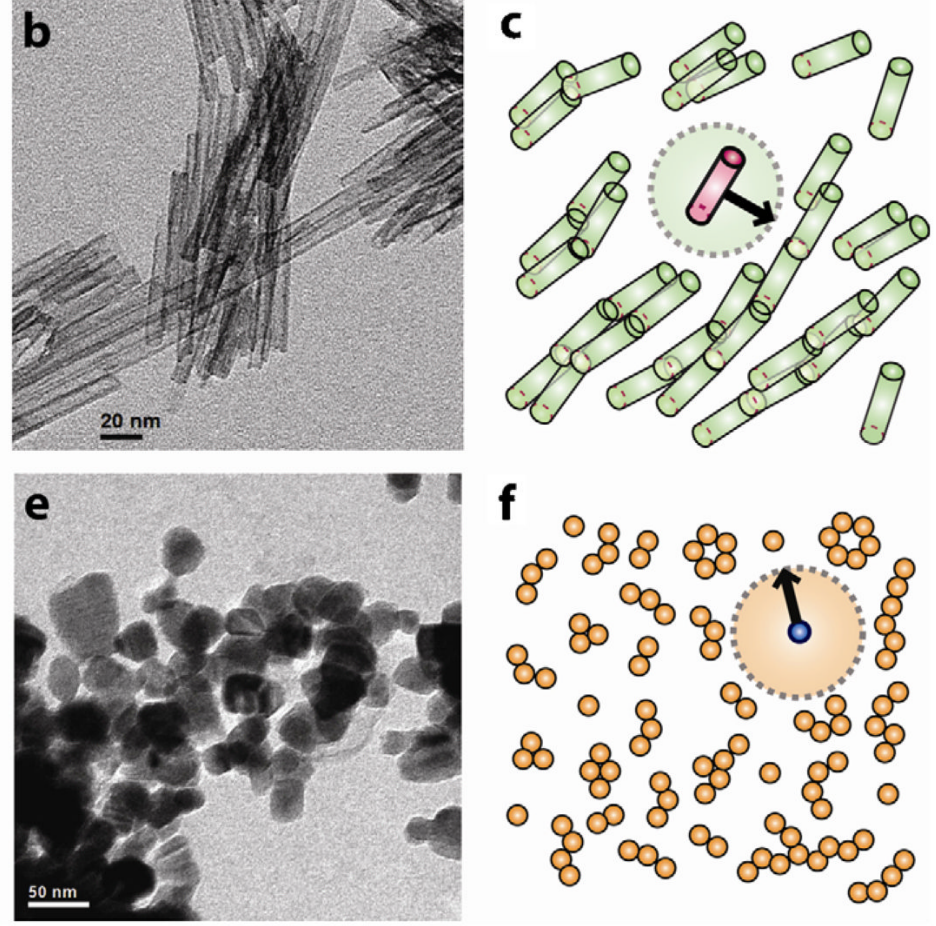

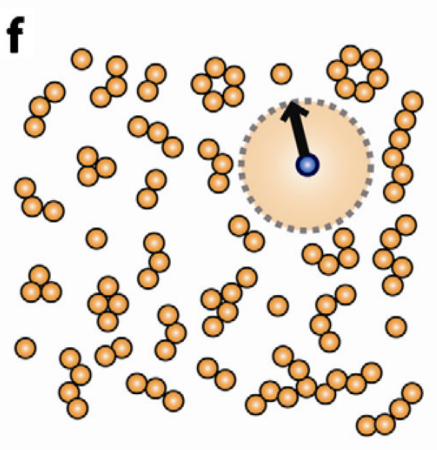

Fig. 11.

Nanoscale imaging of biomolecules and inorganic materials. (Top row) high aspect ratio nanomaterials (e.g. fibrillar, tubular, and rod shaped); (bottom row) low aspect ratio nanostructures (e.g. oligomeric, spherical, and sub-100 nm nanoparticles). (a) AFM image of $\mathrm{A} \beta$, tubular form. (b) TEM image of titanium oxide nanotubes. (c) Illustration representing crystallization schemes for high aspect ratio nanomaterials. (d) AFM image of A $\beta$, oligomeric form. (e) TEM image of titanium oxide nanoparticles. (f) Illustration representing crystallization schemes of spherical nanomaterials. (a) and (d) (the AFM data) were adapted from reference Heo et al. (2007) with permission from the publisher. 

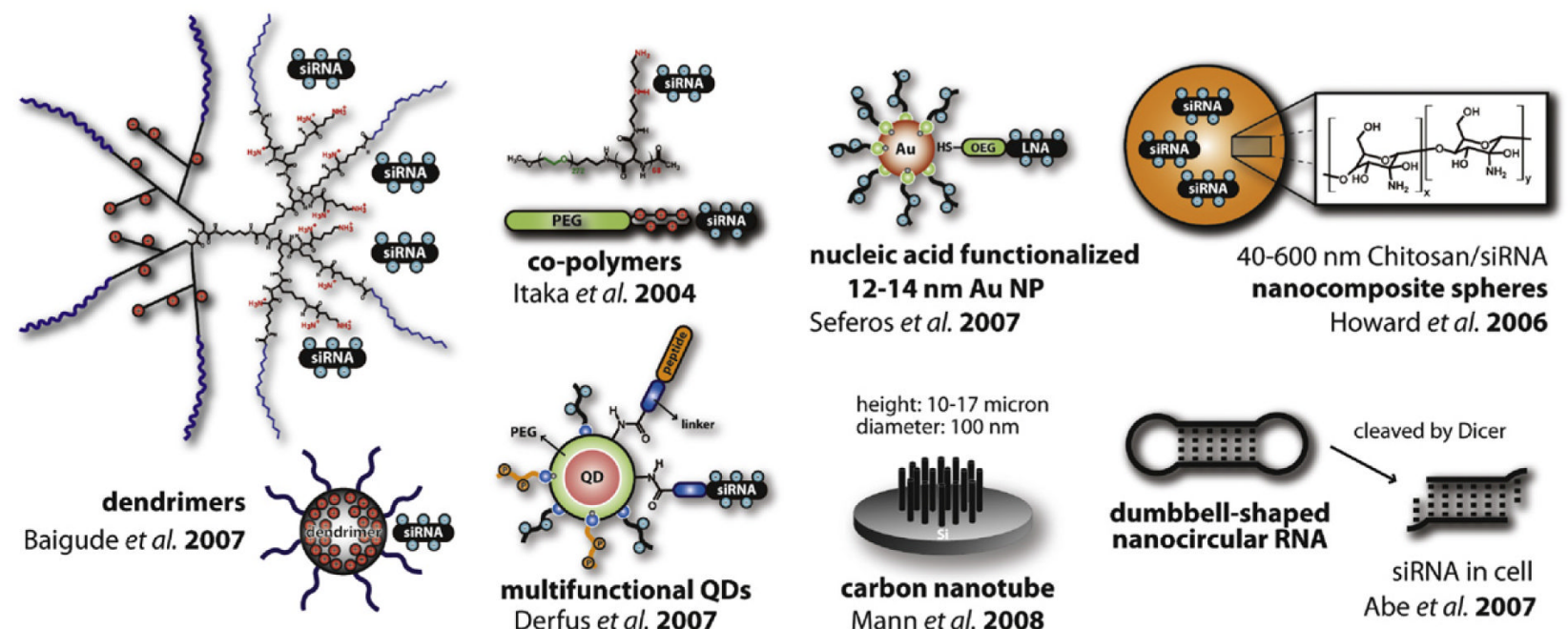

nucleic acid functionalized

40-600 nm Chitosan/siRNA 12-14 nm Au NP Seferos et al. 2007 nanocomposite spheres Howard et al. 2006
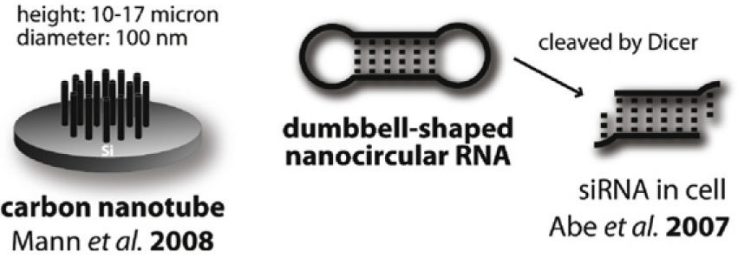

Fig. 12.

RNA interference vehicles. Various shapes and forms are used as tools to deliver RNA that will selectively silence gene translation; examples include dendrimers, copolymers, nucleic acid decorated Au NPs, nanocomposite spheres, multifunctional QDs, carbon nanotube arrays, and nanocircular RNAs. Illustrations were prepared based on data, schemes, and figures appearing in the references with permission from the publisher. 


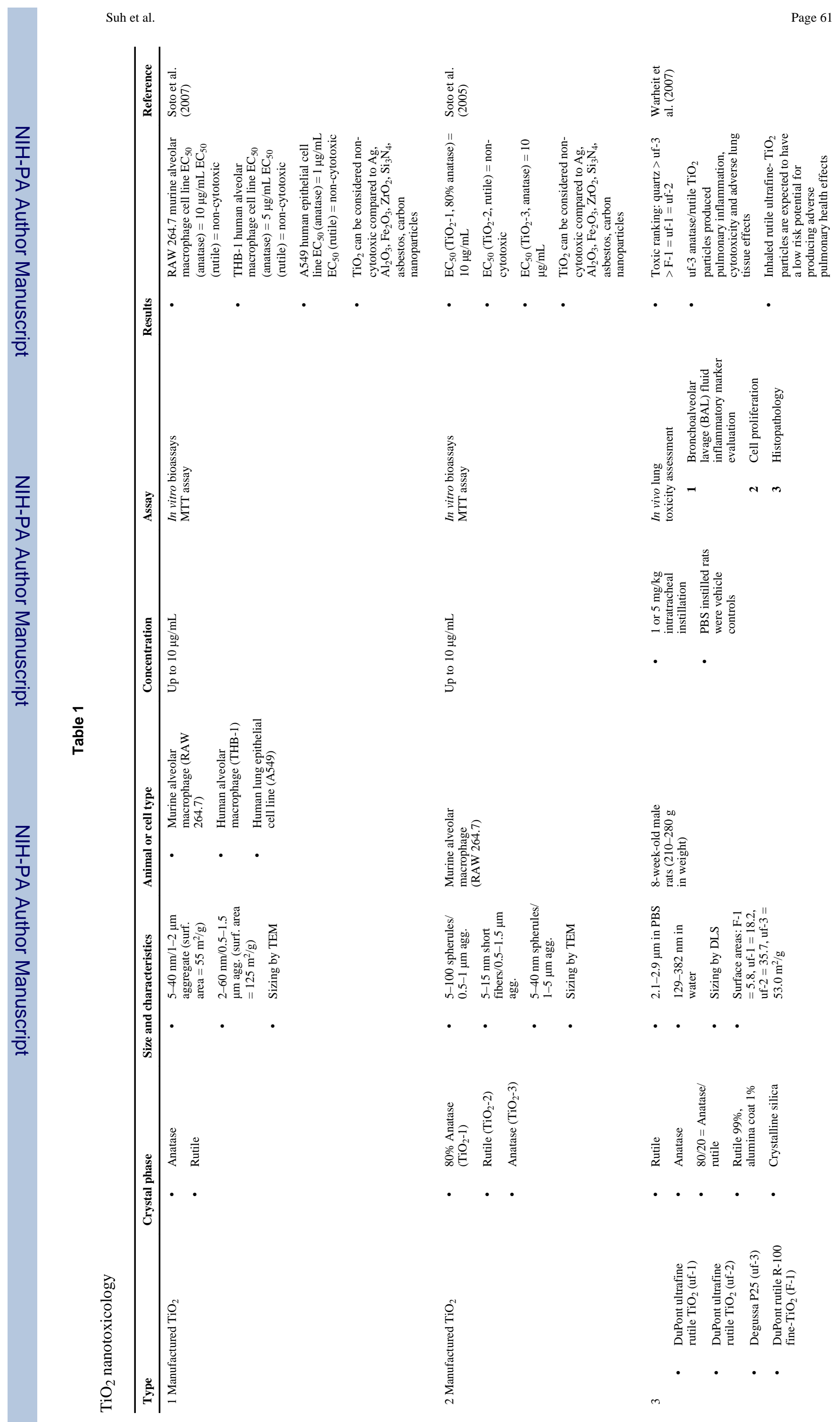




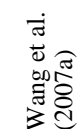

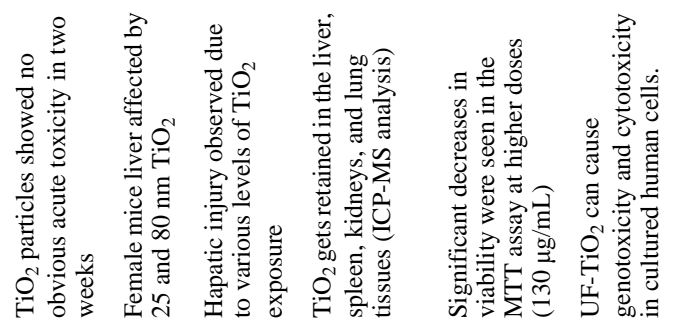

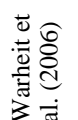

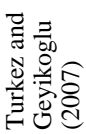
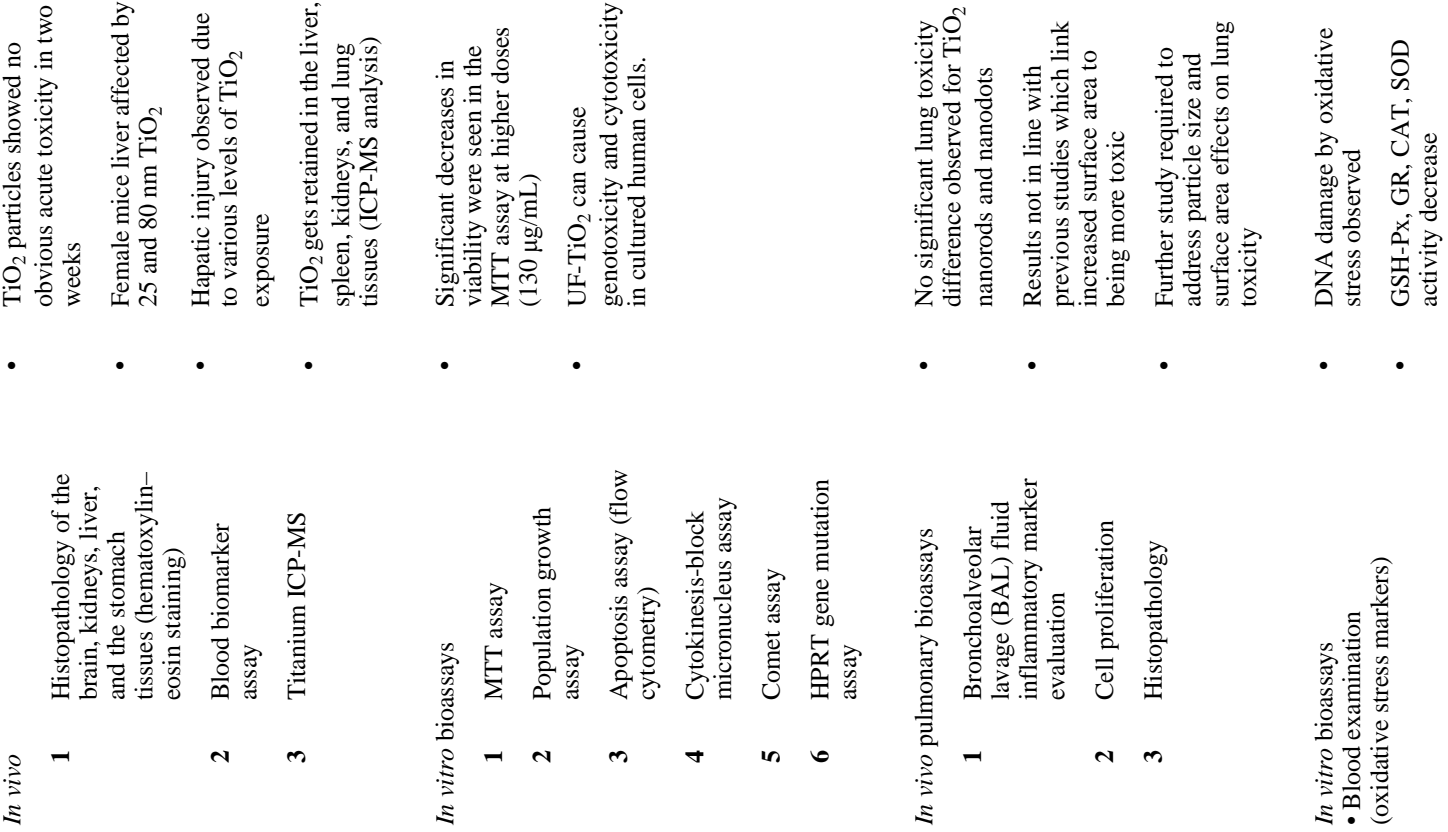

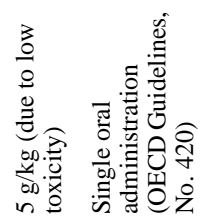

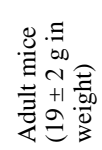

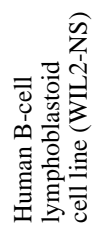

$\frac{\mathrm{g}}{\mathrm{i}}$

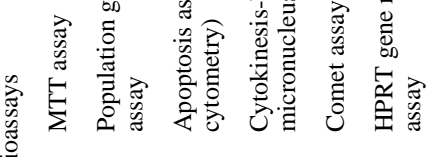

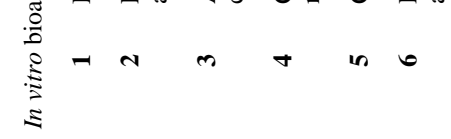

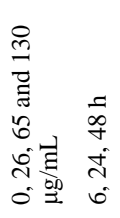

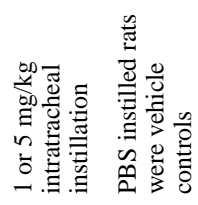

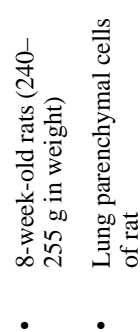

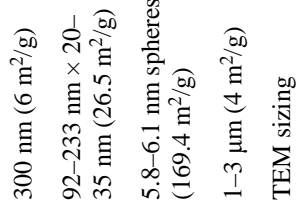

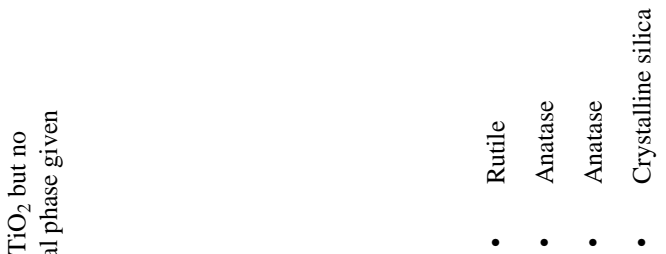

$\overleftrightarrow{z}$

。ํ.

용

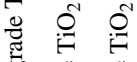

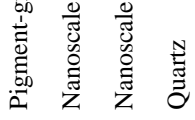

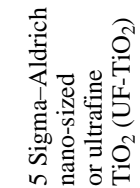

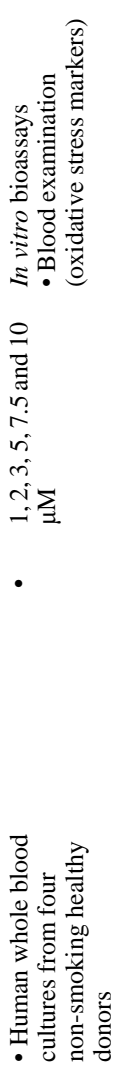

$\overleftarrow{z}$

$\overleftarrow{z}$

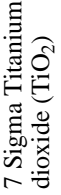




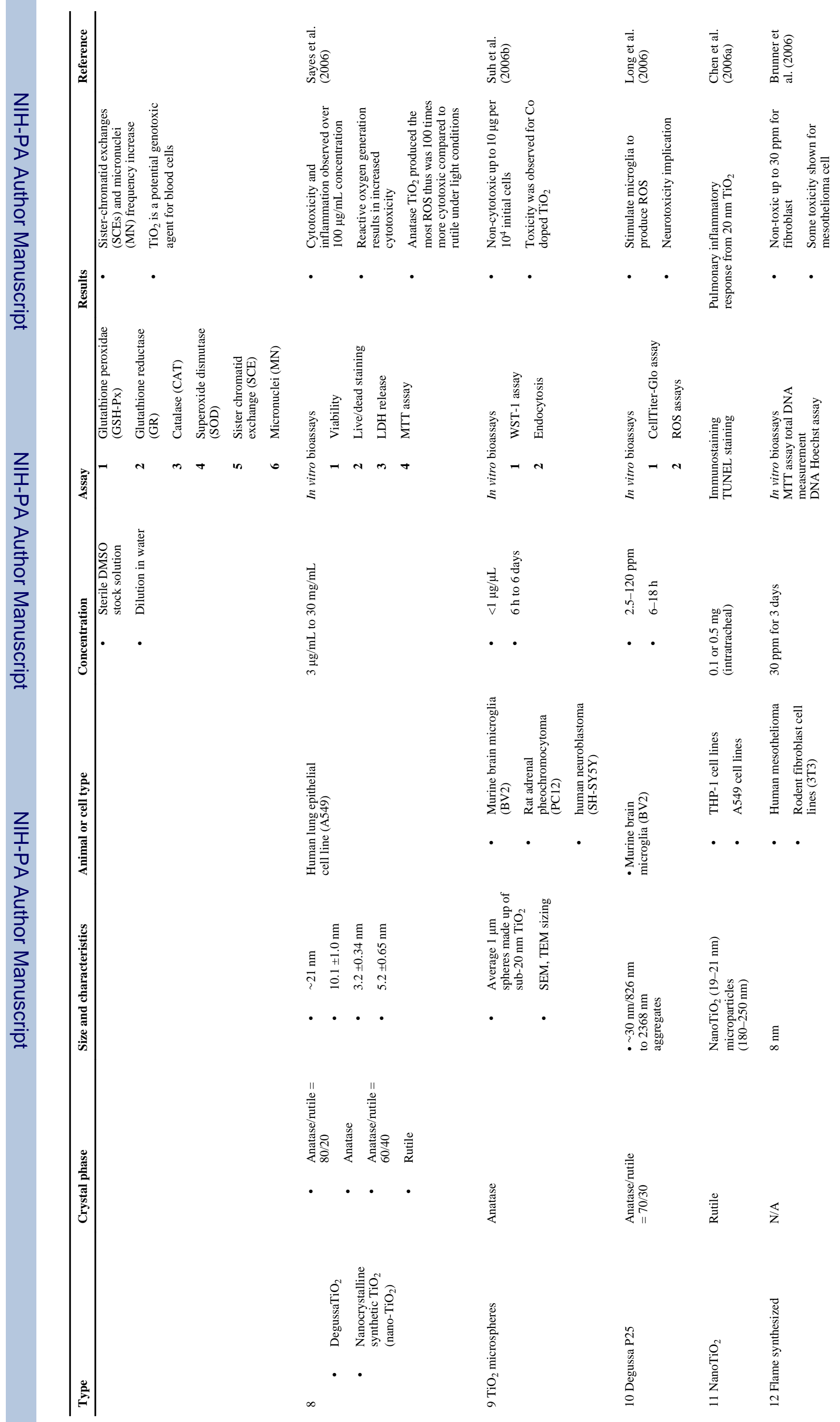




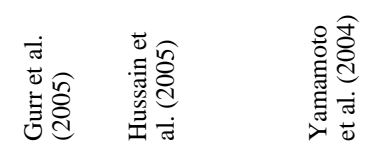

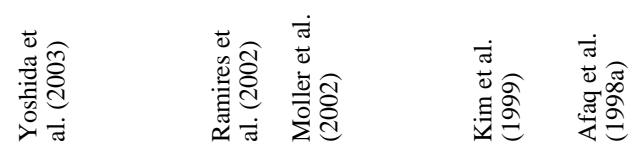

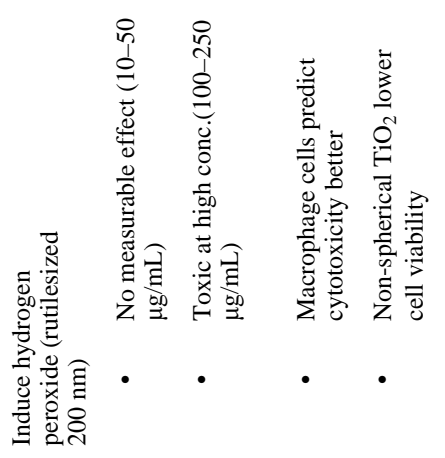

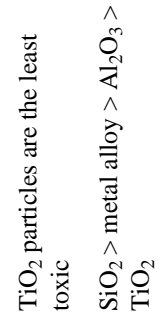

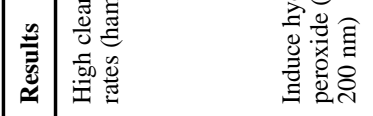

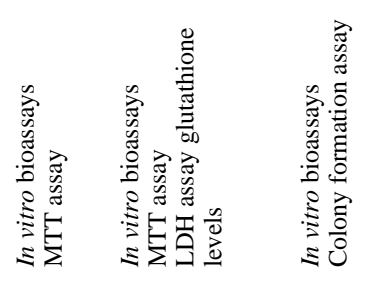

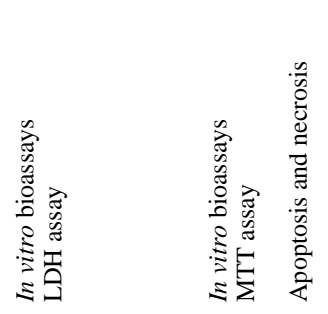
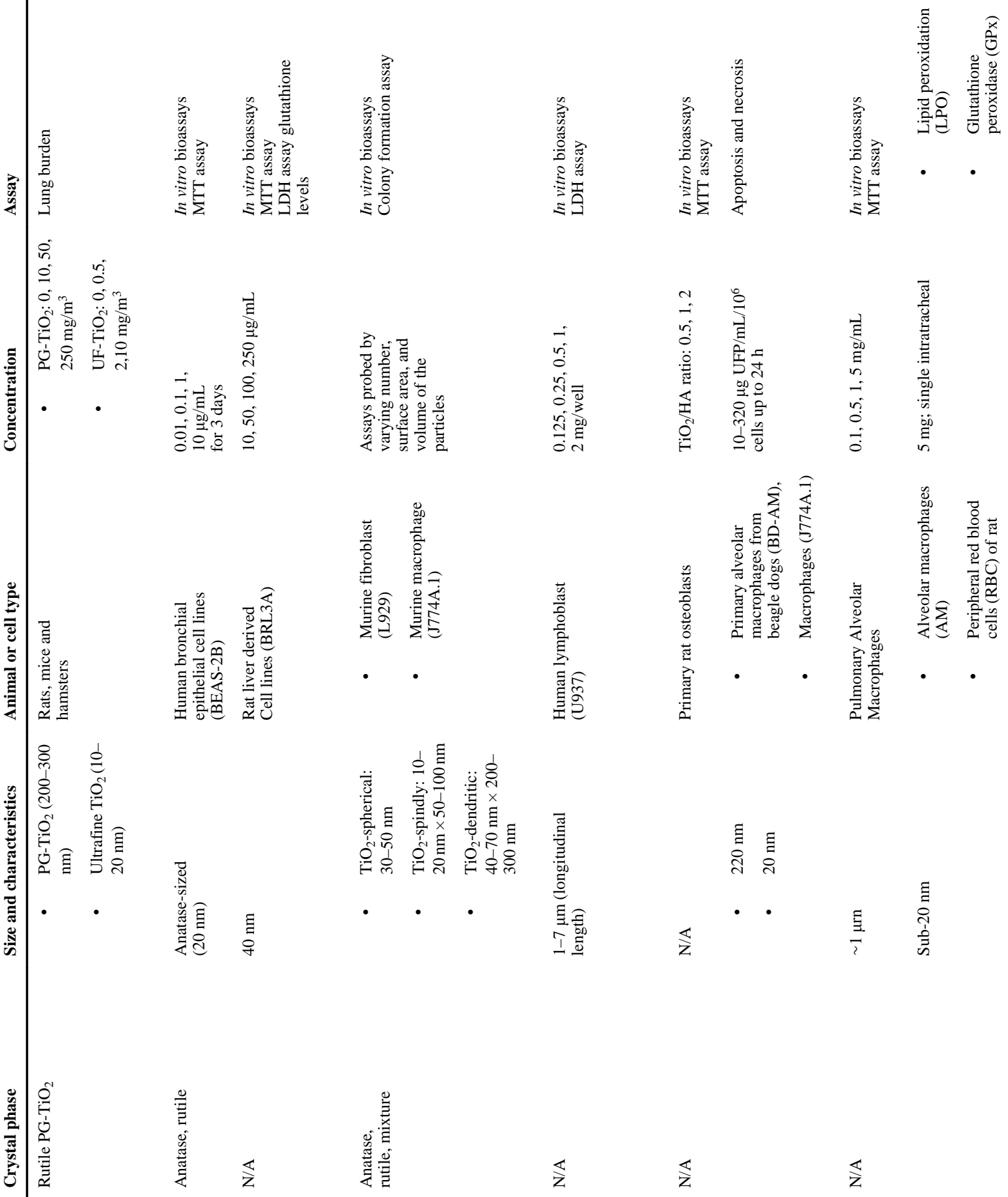

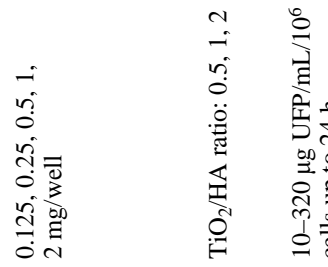

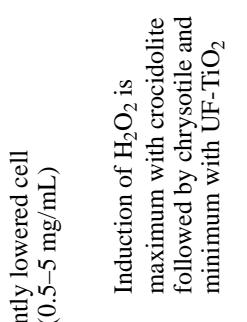

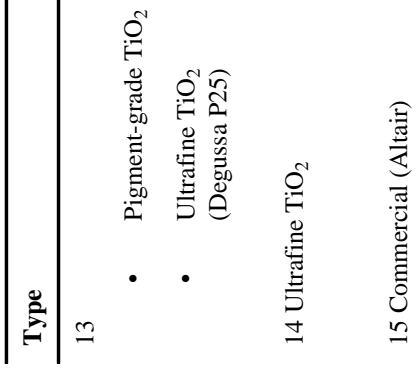

$\mathbb{s} \quad \mathbb{z}$

$\widehat{z}$

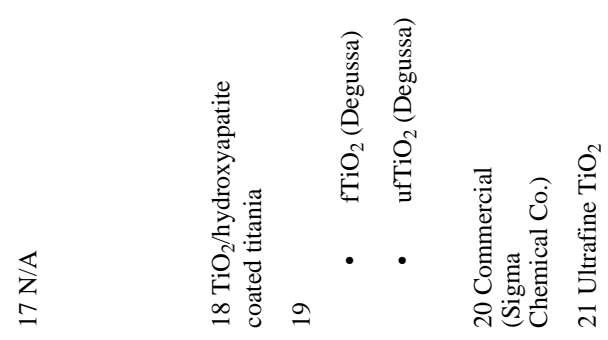




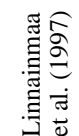

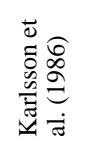

ำ

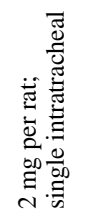

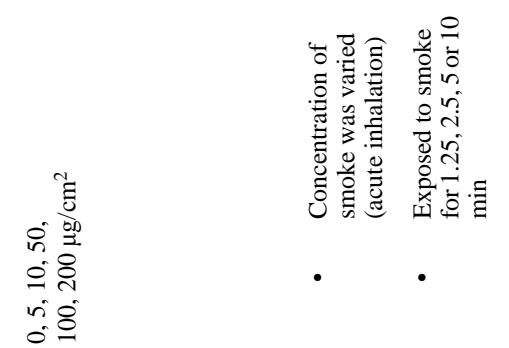

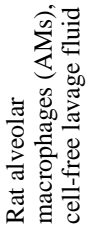

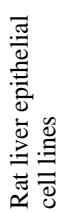

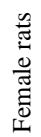

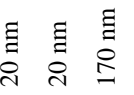

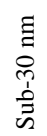

$\overleftrightarrow{z}$

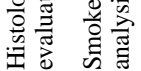
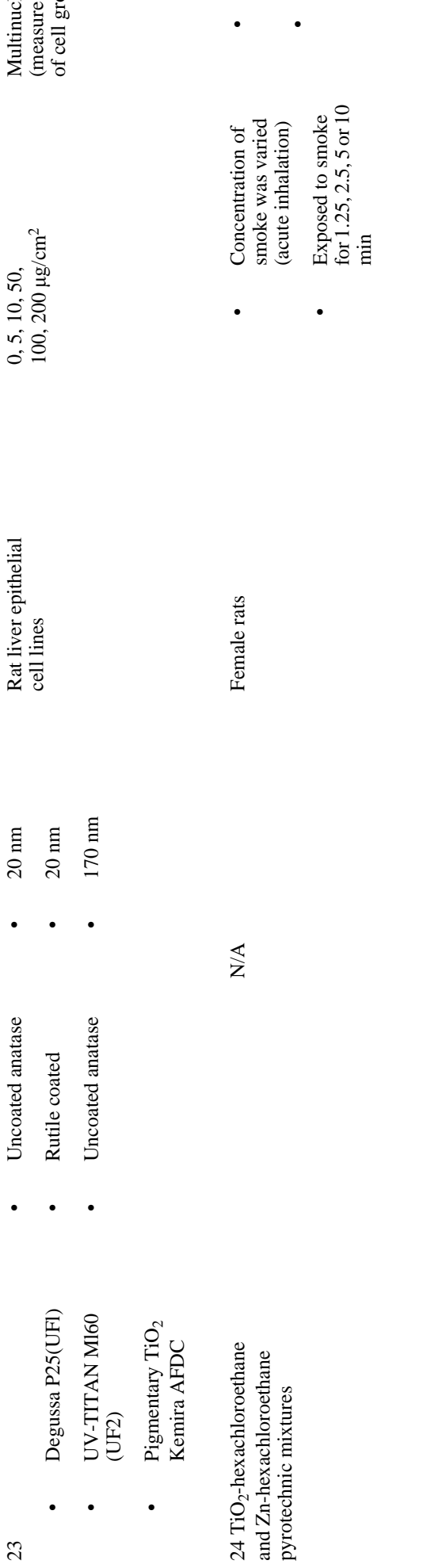


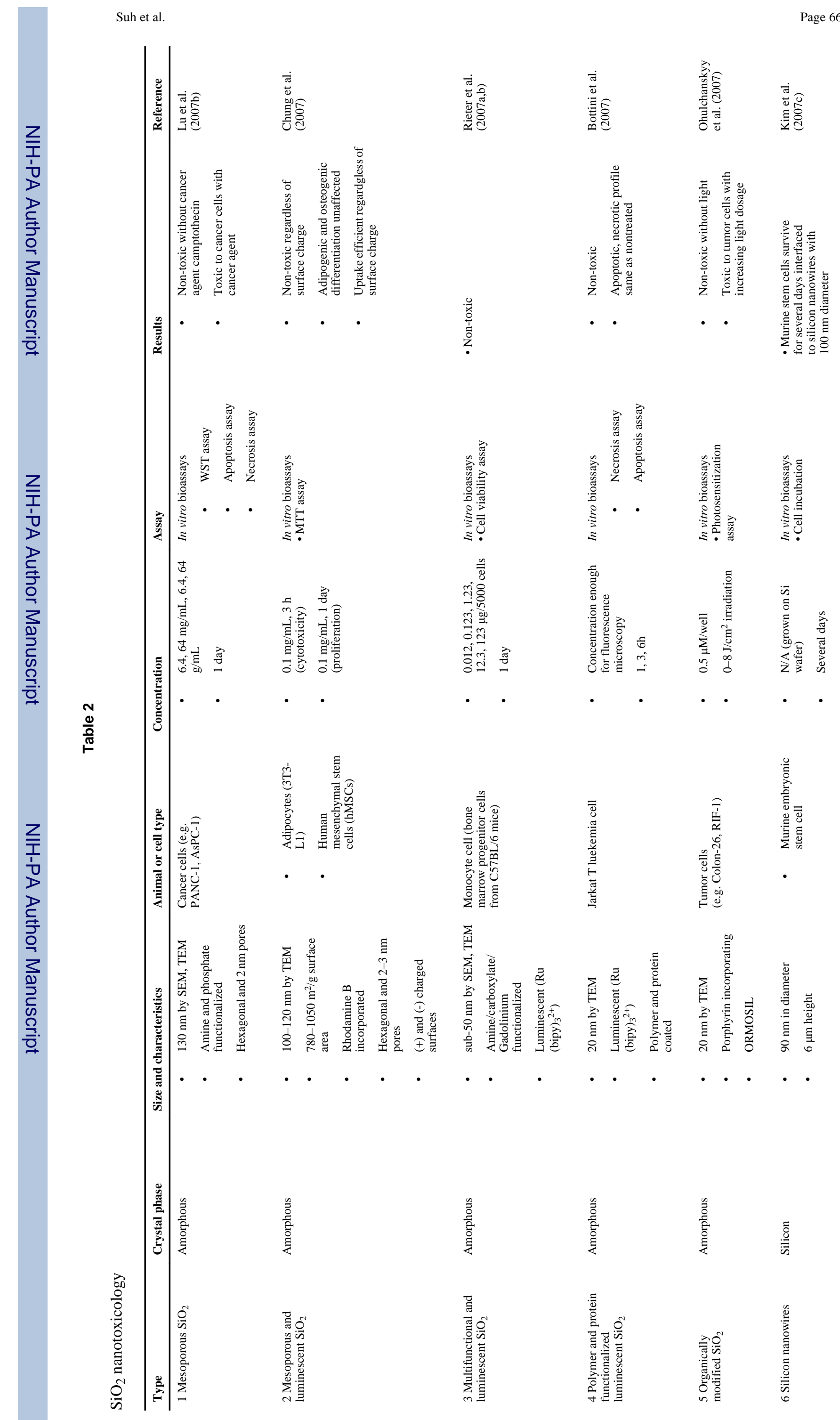


(5)

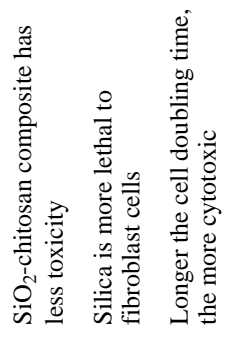

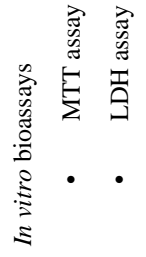

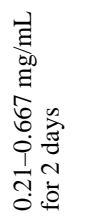

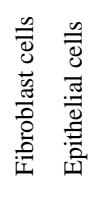

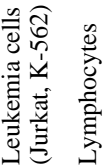

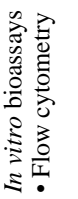

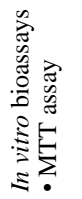

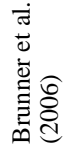

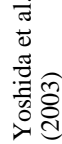

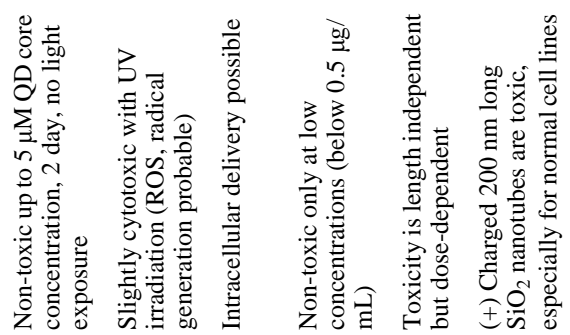

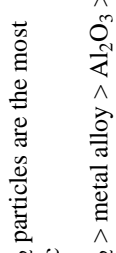

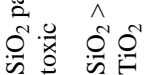

产

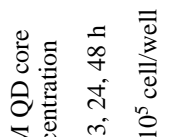

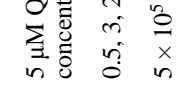

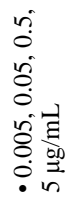

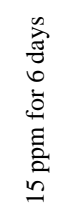

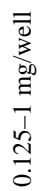

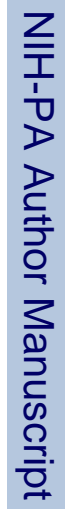

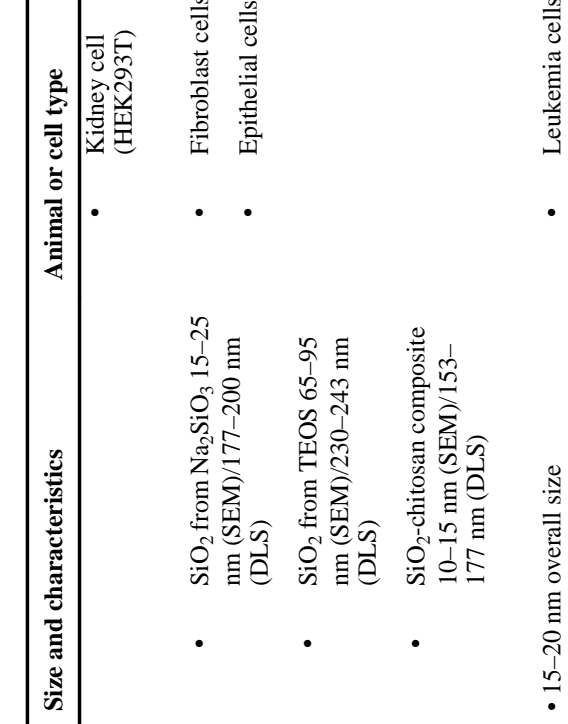

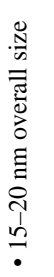
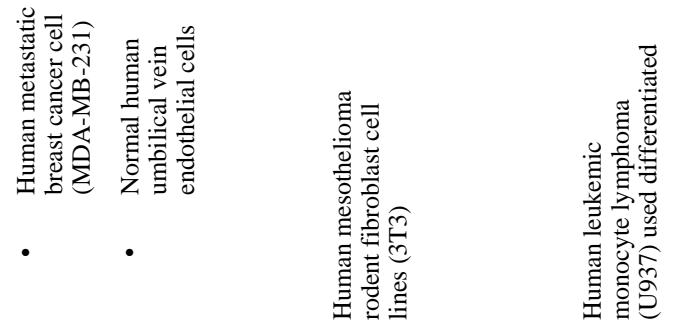

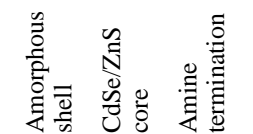

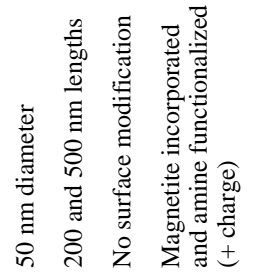

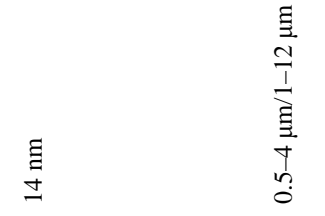

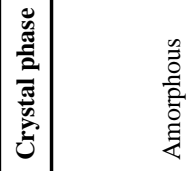

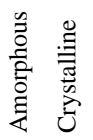

势

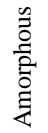

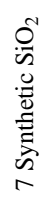

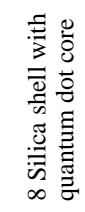

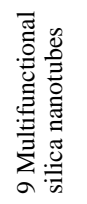

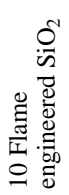

$\underset{z}{\longleftarrow}$ 
远位 竞吉

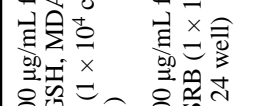

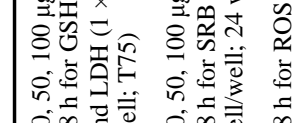

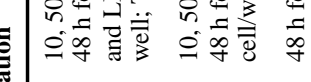

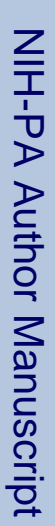

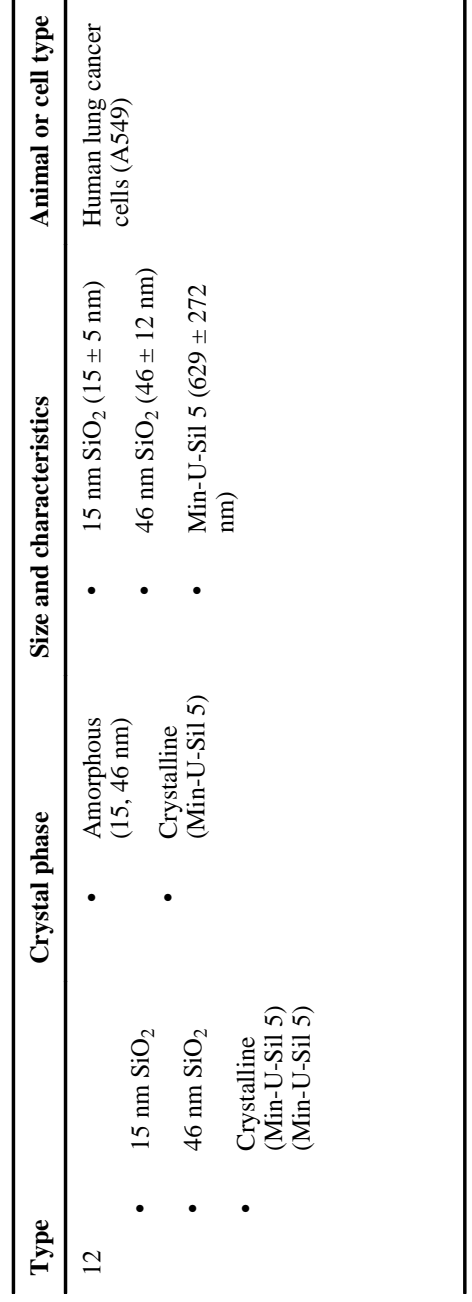




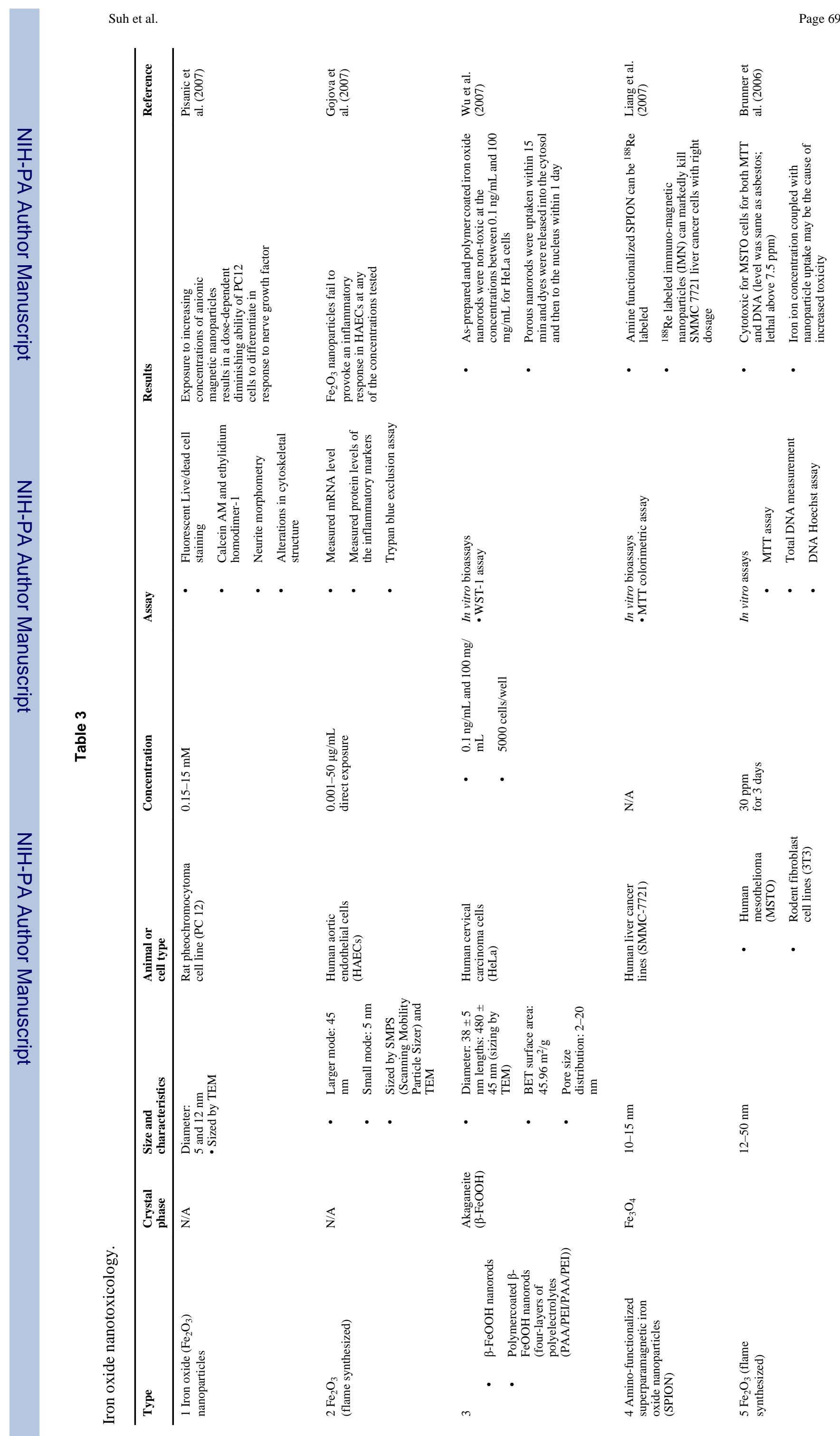




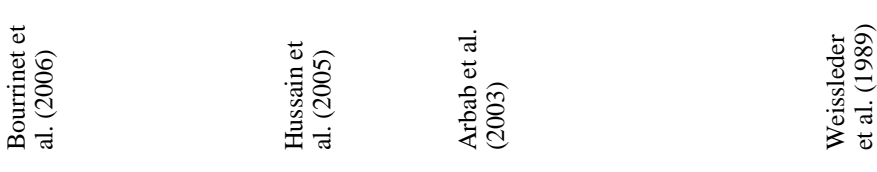

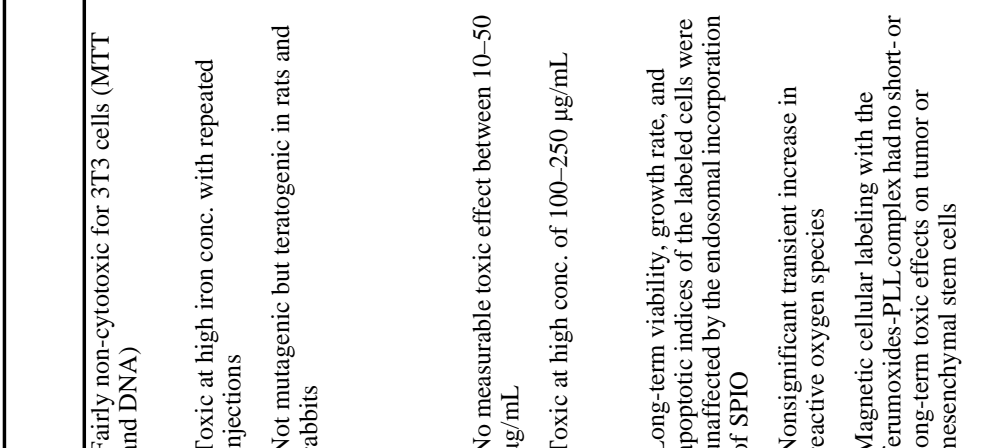

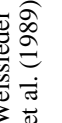

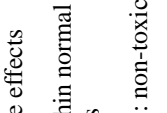

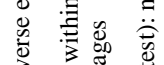

热

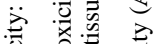

站

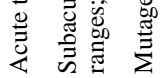

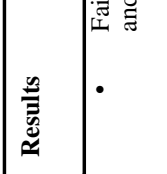

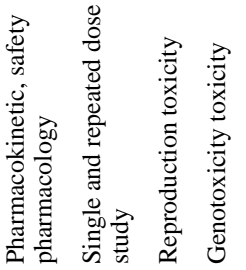

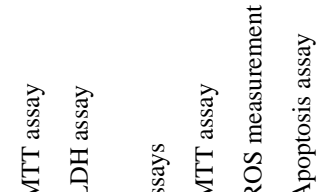

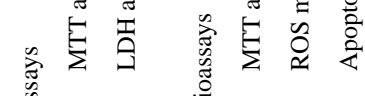

$\cdot \cdot \cdot$

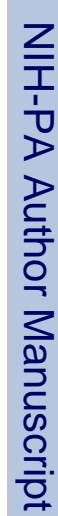

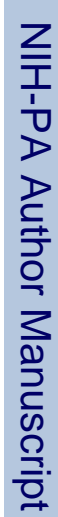

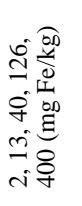

$\Xi$

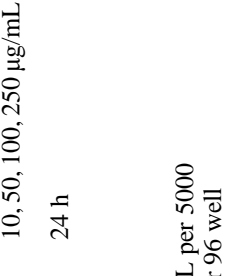

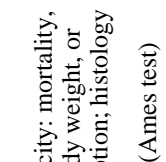

穿家.

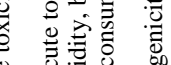

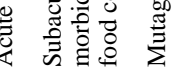

掌 $\cdot \cdot \cdot$

Uี

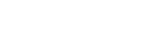

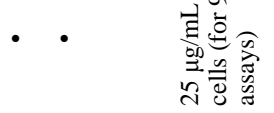

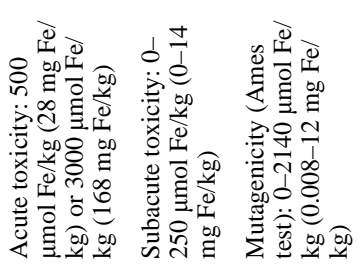

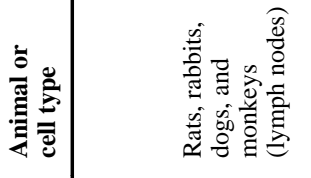

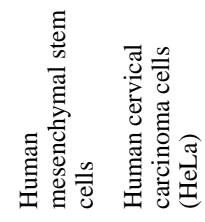

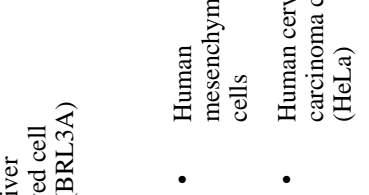

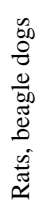

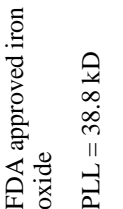

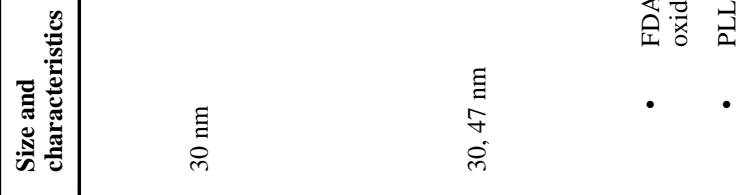

声

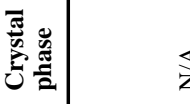

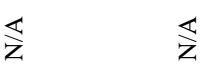

$\overleftrightarrow{z}$

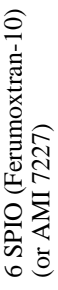

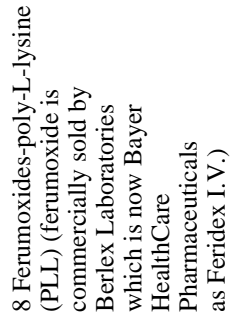

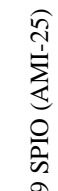




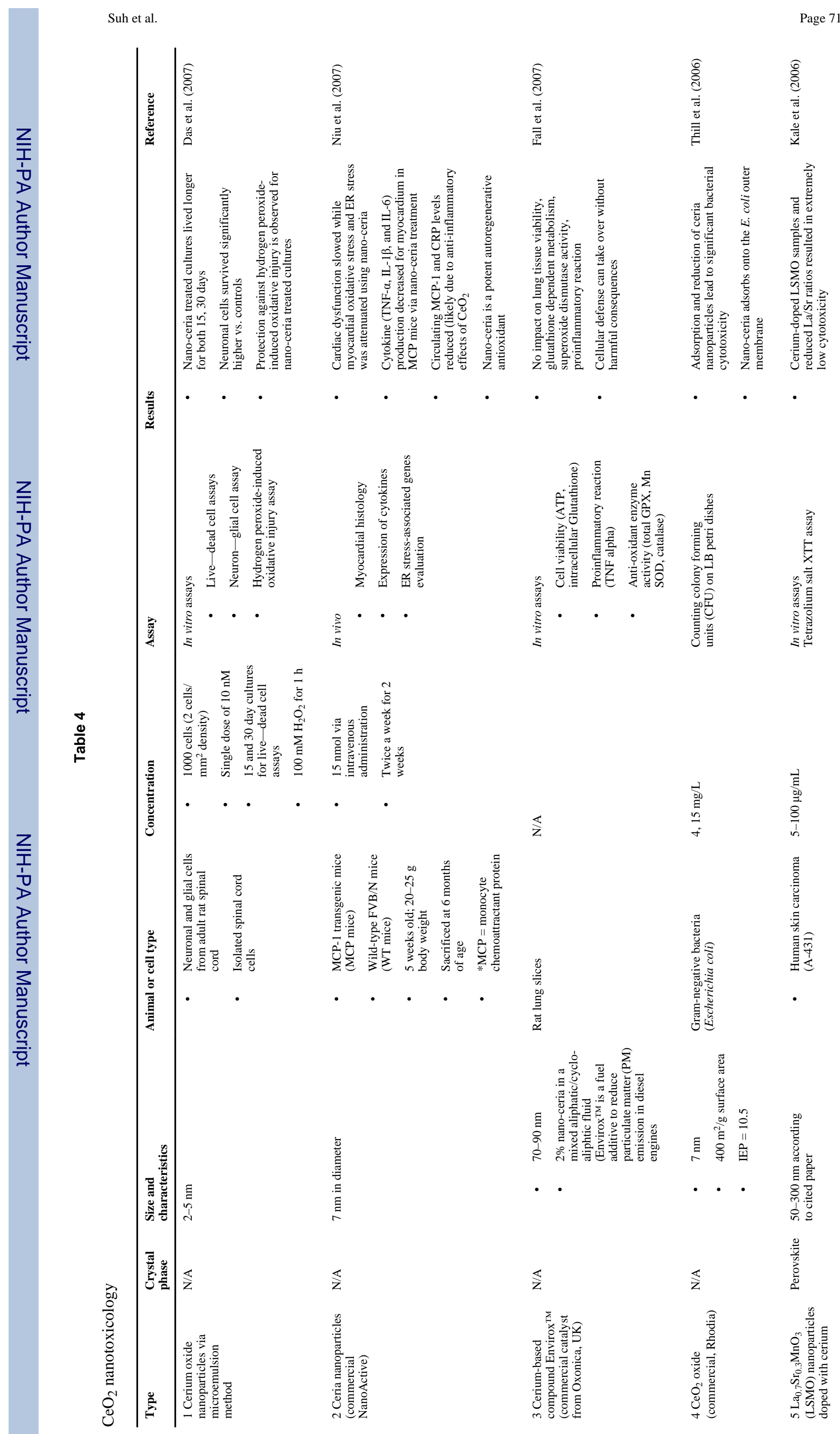




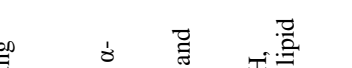

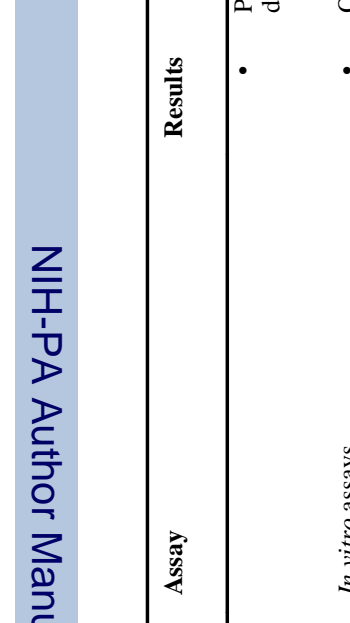

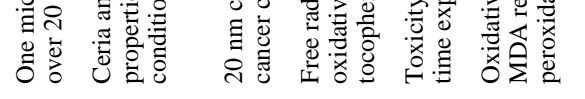

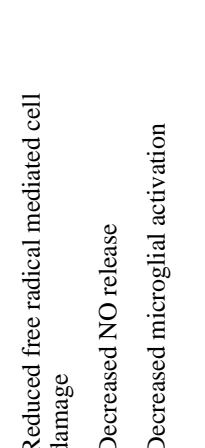

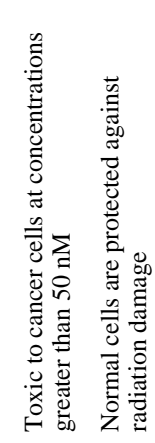

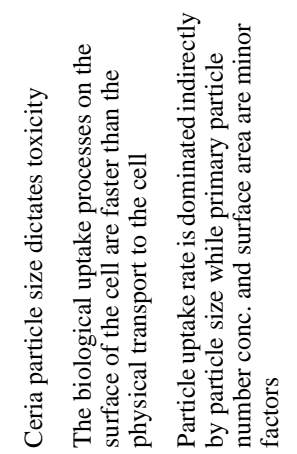

只

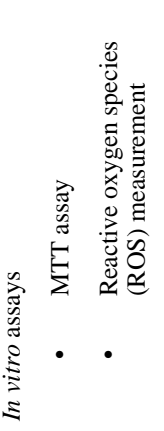

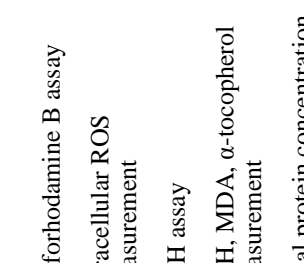

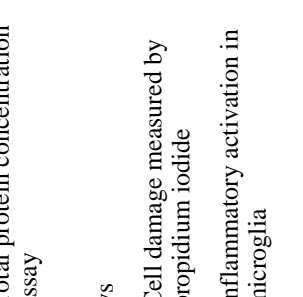

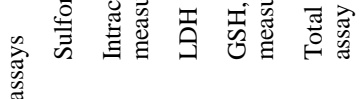

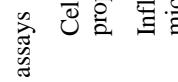

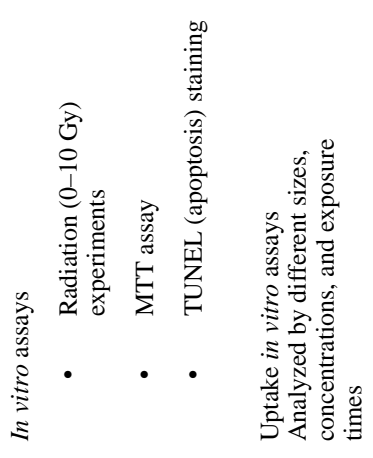

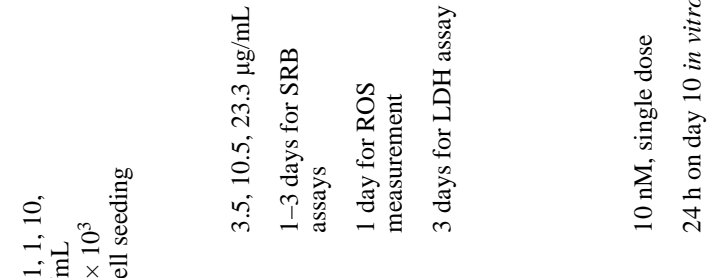

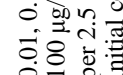

0.

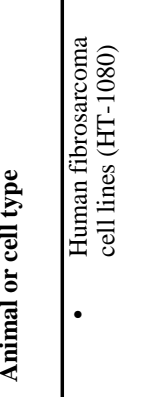

$\overline{8}$

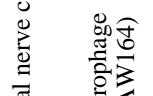

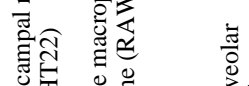

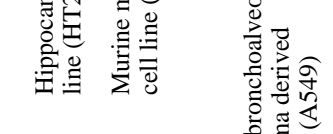

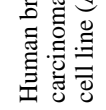

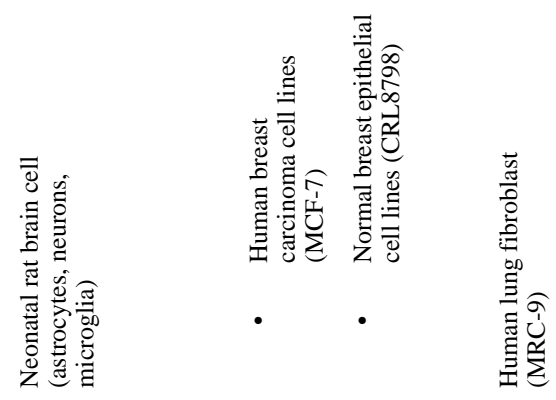
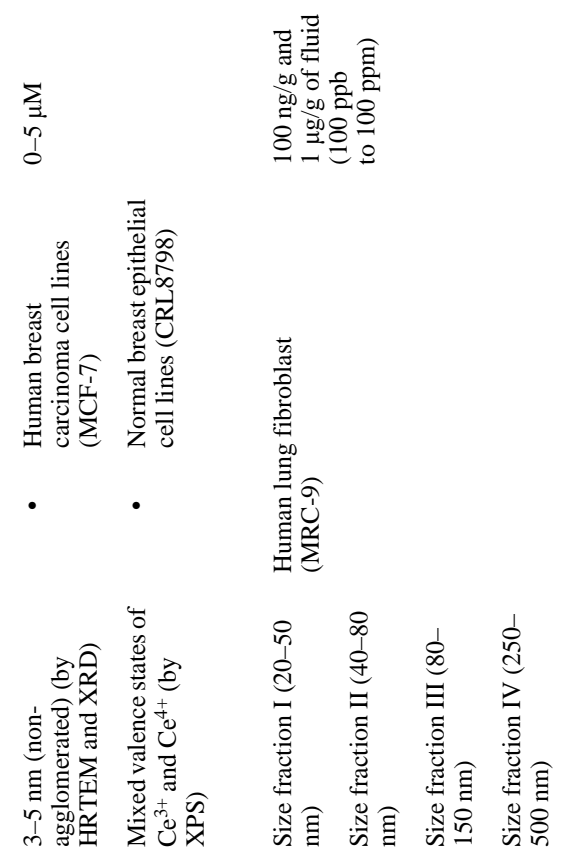

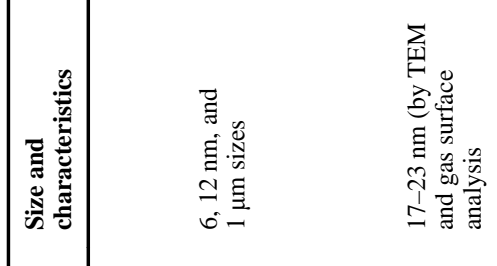

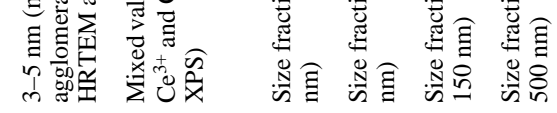

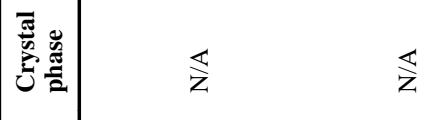

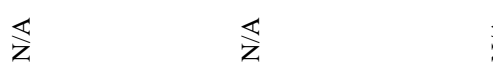

卙
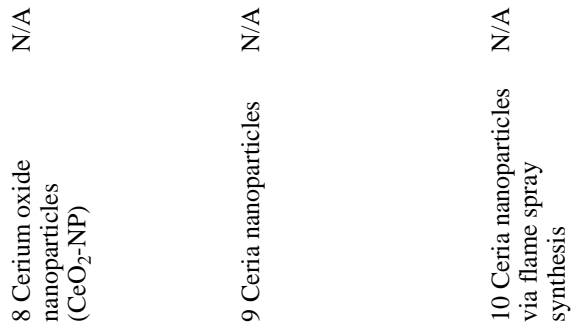


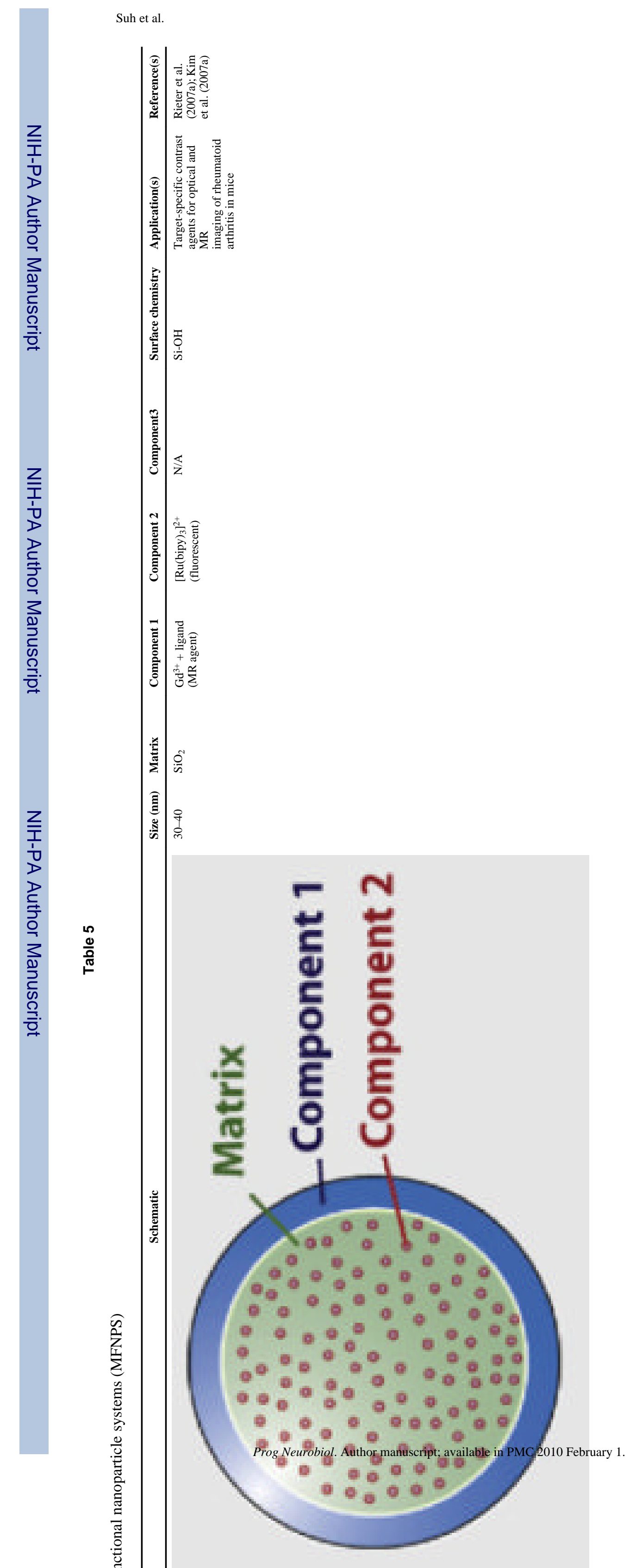




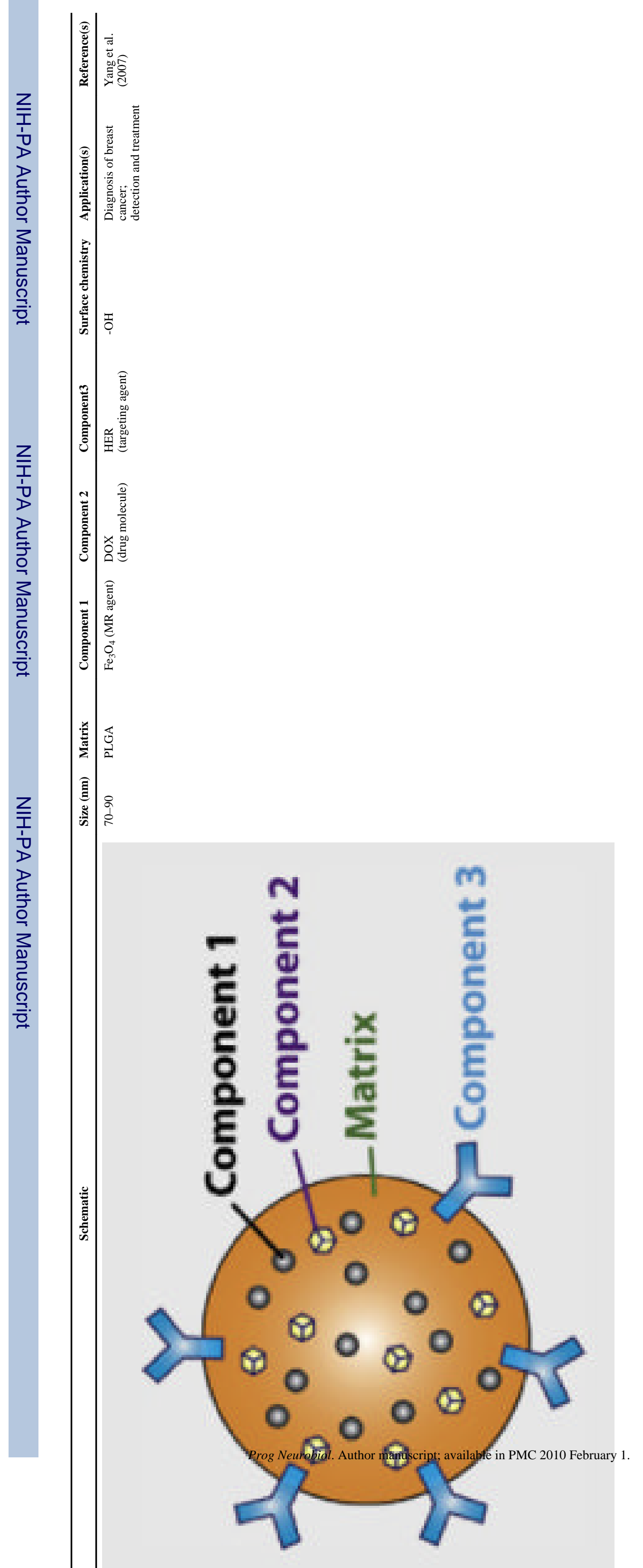




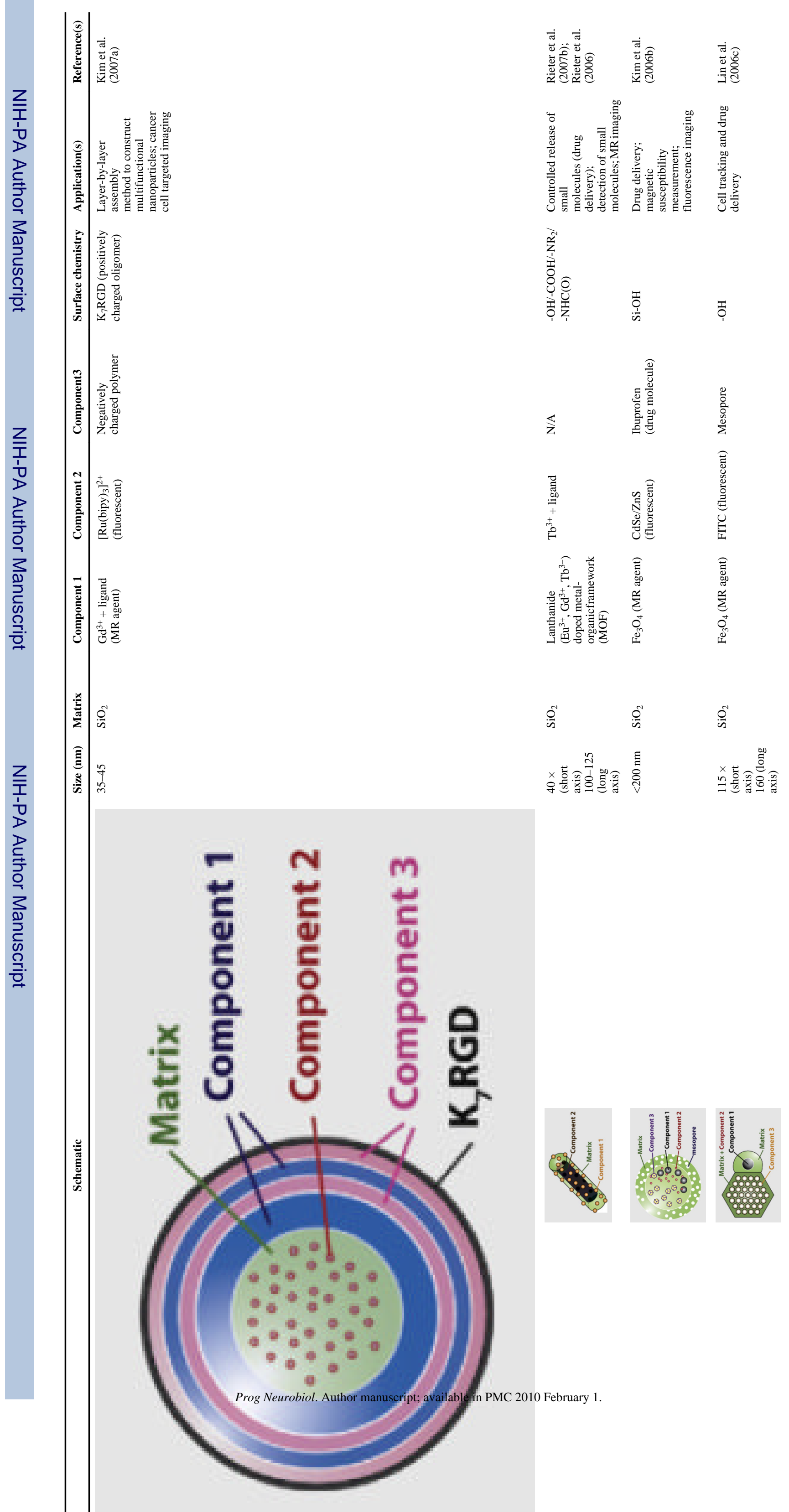

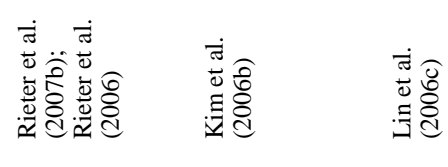

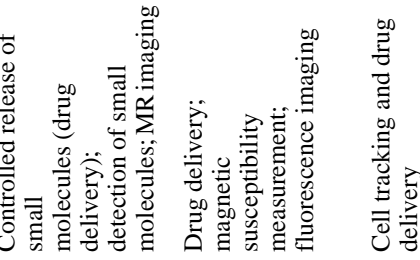

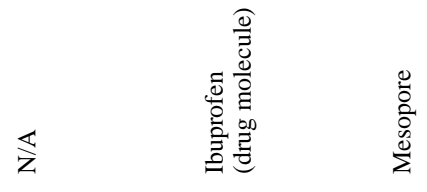

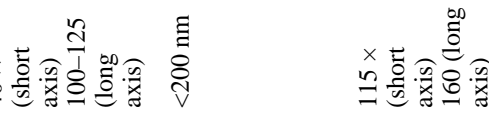




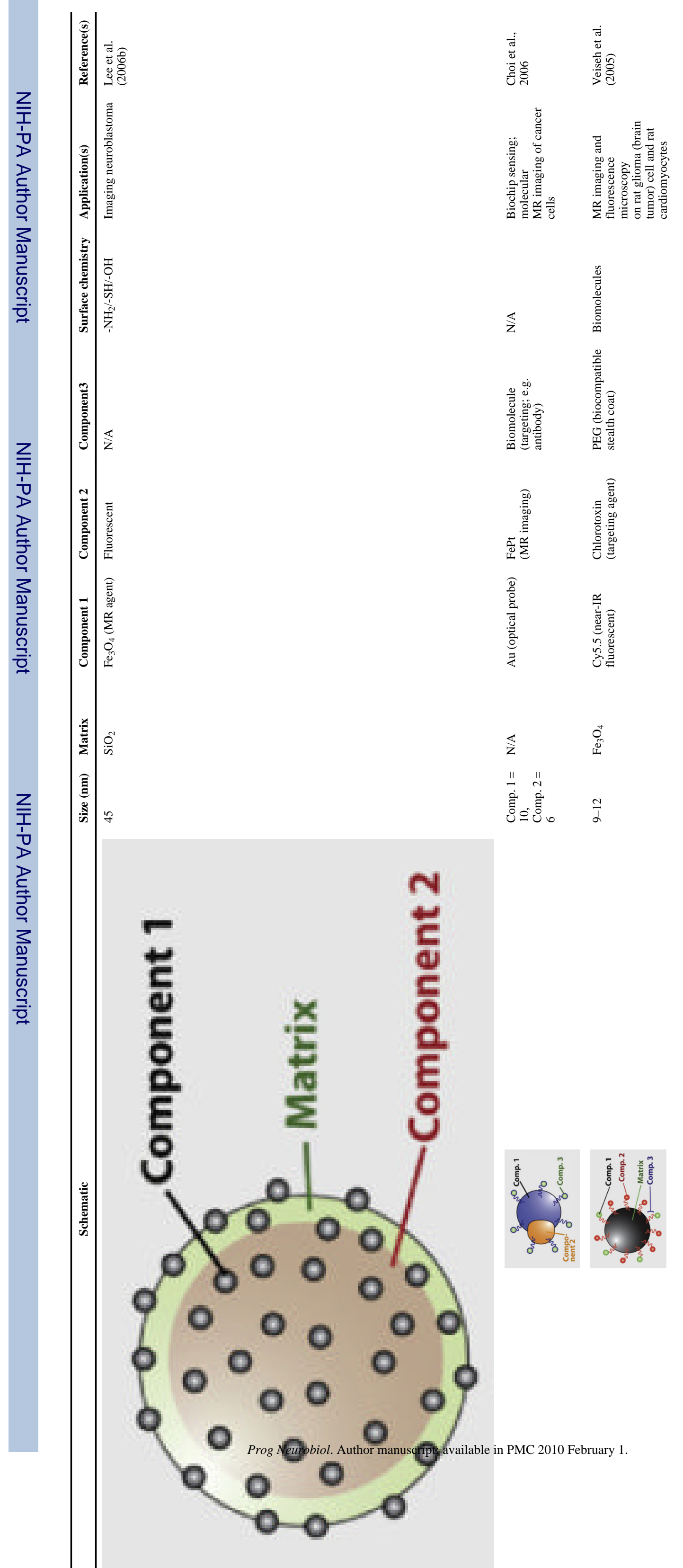




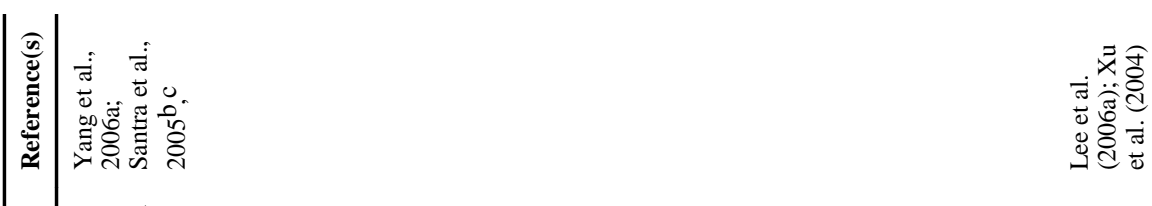

㺼焉

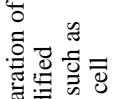

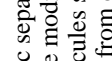

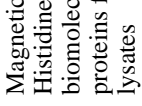

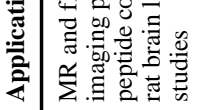

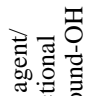

紫要

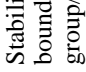

$\overleftrightarrow{z}$

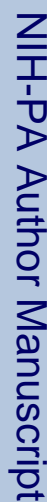

กิ

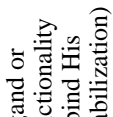

究

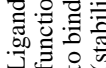

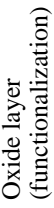

용

蒂

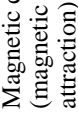

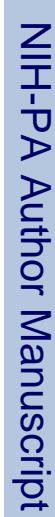

突

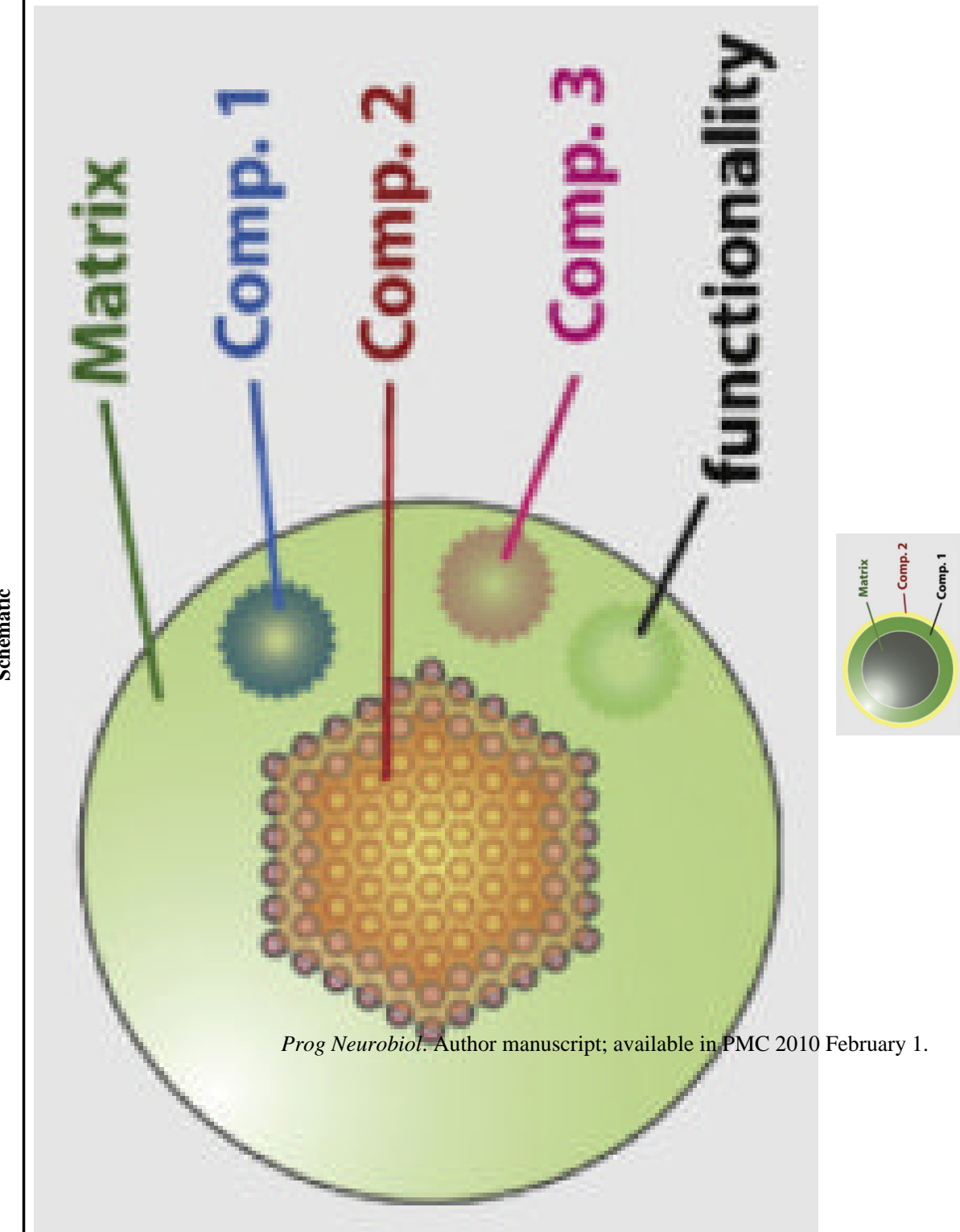




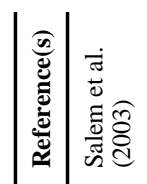

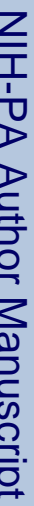

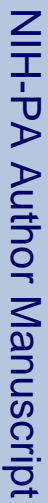

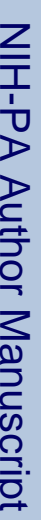

.

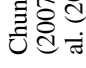

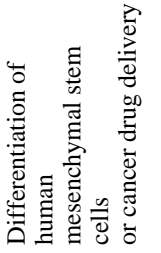

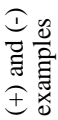

壳

$\frac{2}{2}$

旁产

임

웜

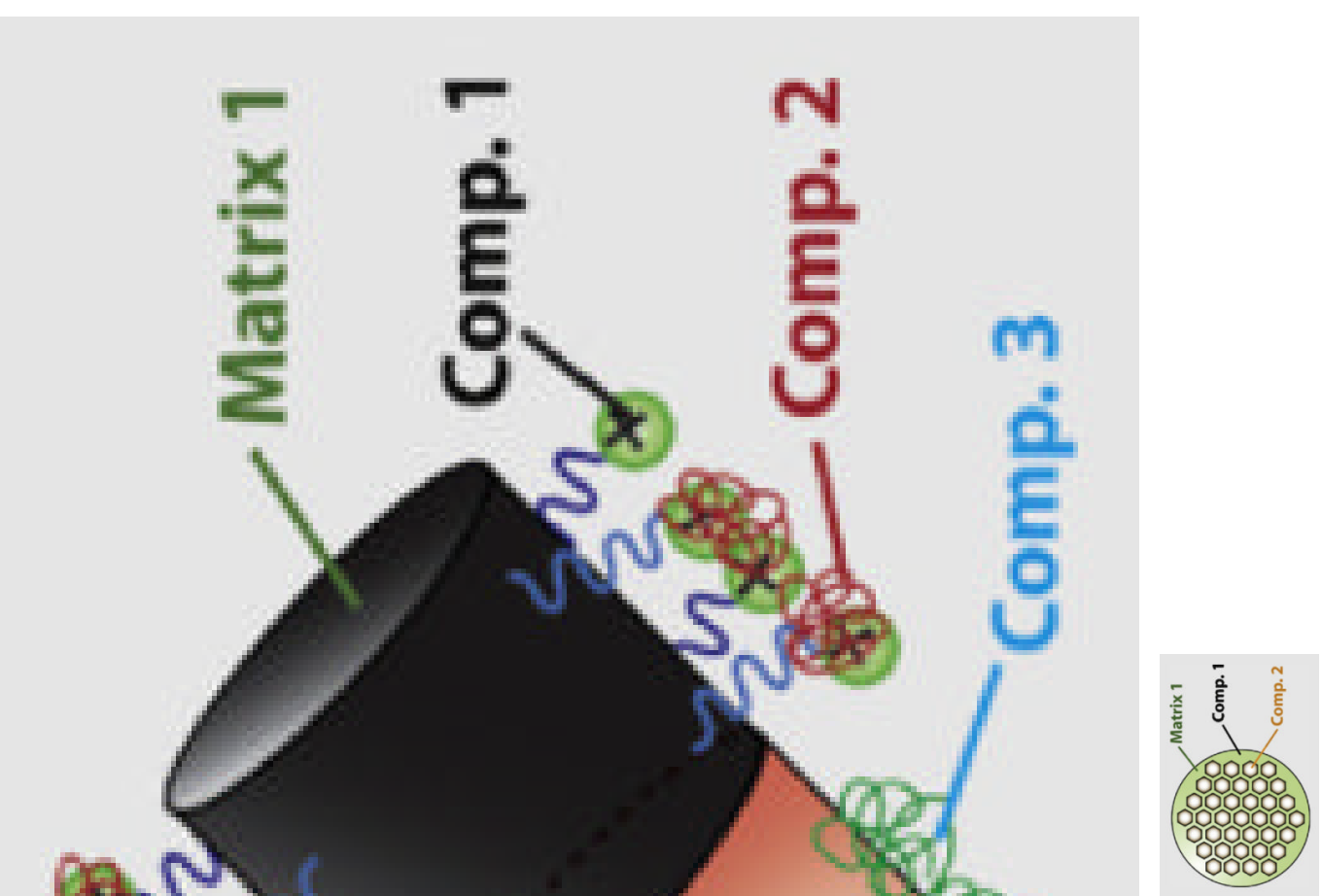


